STATE OF ALASKA

DEPARTMENT OF NATURAL RESOURCES

\title{
GEOLOGICAL LITERATURE ON THE NORTH SLOPE OF ALASKA, 1974-80
}

Compiled by Karen S. Emmel

SPECIAL REPORT 29

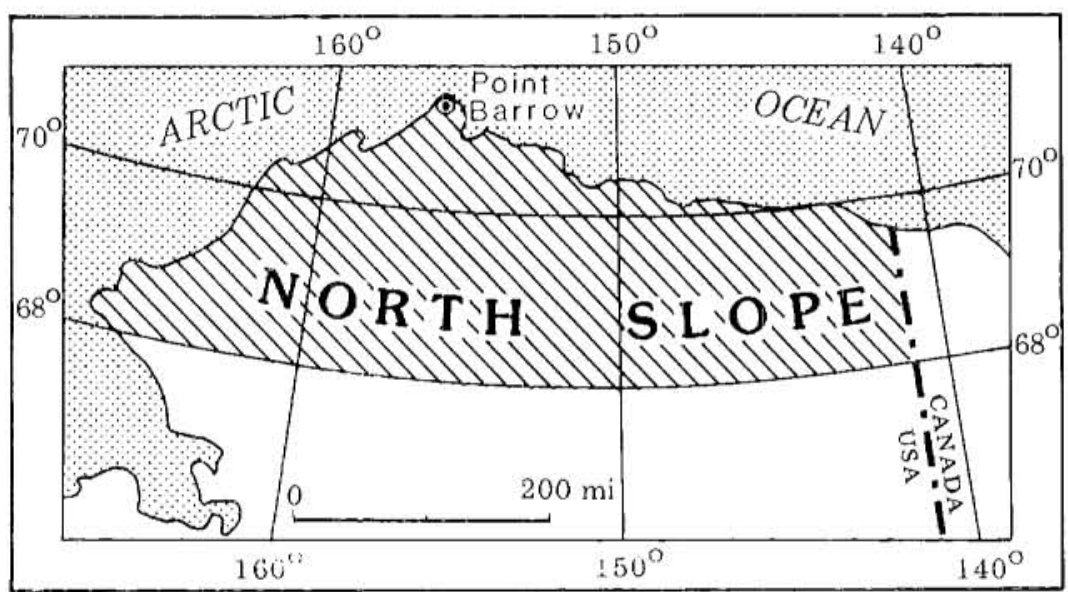

Pubiished by

DIVISION OF GEOLOGICAL \& GEOPHYSICAL SURVEYS

Anchorage, Alaska

1982

ROSS G. SCHAFF

STATE GEOLOGIST 
GEOLOGICAL LITERATURE ON THE NORTH SLOPE OF ALASKA, 1974-80

Compiled by Karen S, Emmel

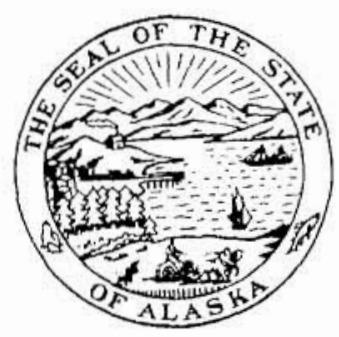


Jay S. Hammond, Governor

John W. Katz, Commissioner, Dept. of Natural Resources

Geoffrey Haynes, Deputy Commissioner

Ross G. Schaff, State Geologist

Available from Alaska Division of Geological and Geophysical Surveys, P.O. Box 80007, College, $99708 ; 323$ E. 4 th Ave., Anchorage, 99501 ; P.O. Box 7438, Ketchikan, 99901; and 230 So. Franklin St. (Rm 407), Juneau, 99801 . Price \$1. 


\section{CONTENTS}

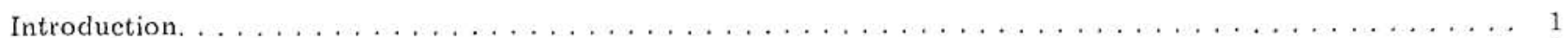

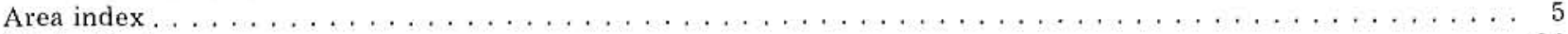

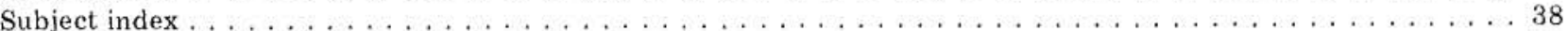

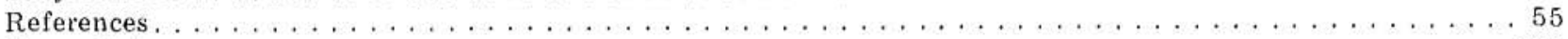

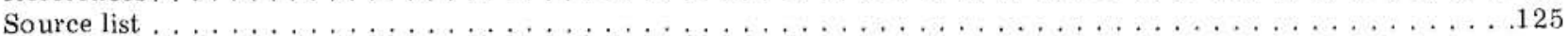

\section{ILLUSTRATIONS}

Figure 1. Index map of northern Alaska showing physiographic provinces and National Petroleum Reserve -

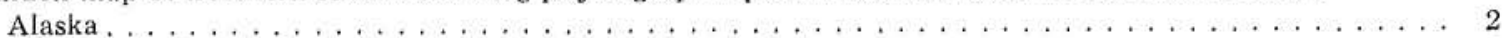

2. Index map of Alaska showing USGS quadrangles on North Slope . . . . . . . . . . . . . . 3

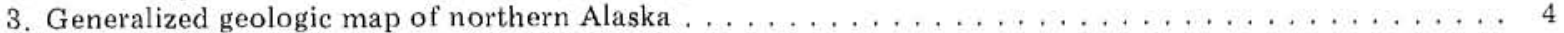


Geological 1iterature on the North Slope of Alaska, 1974-80

Compiled by Karen S. Emmel

\section{INTRODUCTION}

This collection includes references to most geological literature published between July 1974 and December 1980 on that part of Alaska north of $68^{\circ}$. Most reports on offshore areas are included, as are some reports on adjacent areas in Canada. The cover map shows the area encompassed by the literature in this compilation, and figure 1 shows the general geology of the area. National Petroleum Reserve - Alaska, formerly Naval Petroleum Reserve 4, occupies onethird of the Arctic Coastal Plain and the Arctic Foothills provinces

(Wahrhaftig, 1965) (fig. 2).

In the search for references, special emphasis was placed on petroleum geology and related fields. Trade journals provided many of the entries. Mining and mineral-deposit geology are represented, but no effort was made to examine the trade journals in this field. Because of its impact on exploration and development, permafrost is also represented, but no exhaustive effort was made to include all articles.

The reports are indexed on both a subject and an area basis. The subject index is a simple, one-entry 1 isting based on the title. Thus, reports entitled "Geology and paleontology of..." are listed under "Geology."

The area index is based largely on the work of Edward H. Cobb, of the U.S. Geological survey. In his annual bibliographies, the reports of the USGS, the Alaska Division of Geological and Geophysical Surveys, and the U.S. Bureau of Mines are indexed by quadrangle. Two special bibliographies by Cobb also index the articles of the Anerican Association of Petroleum Geologists and the Geological Society of America. Reports from other sources are indexed by title. Where possible, these reports are listed by quadrangle; otherwise, they are listed under more general area listings. Figure 3 shows the quadrangles north of $68^{\circ}$

The author wishes to thank both $\mathrm{Mr}$. Cobb and the staff of the Alaska Resources Library for their assistance in compiling this bibliography.

\section{REFERENCE}

Wahrhaftig, Clyde, 1965, Physiographic divisions of Alaska: U.S. Geological Survey Professional Paper 482, $52 \mathrm{p}$. 


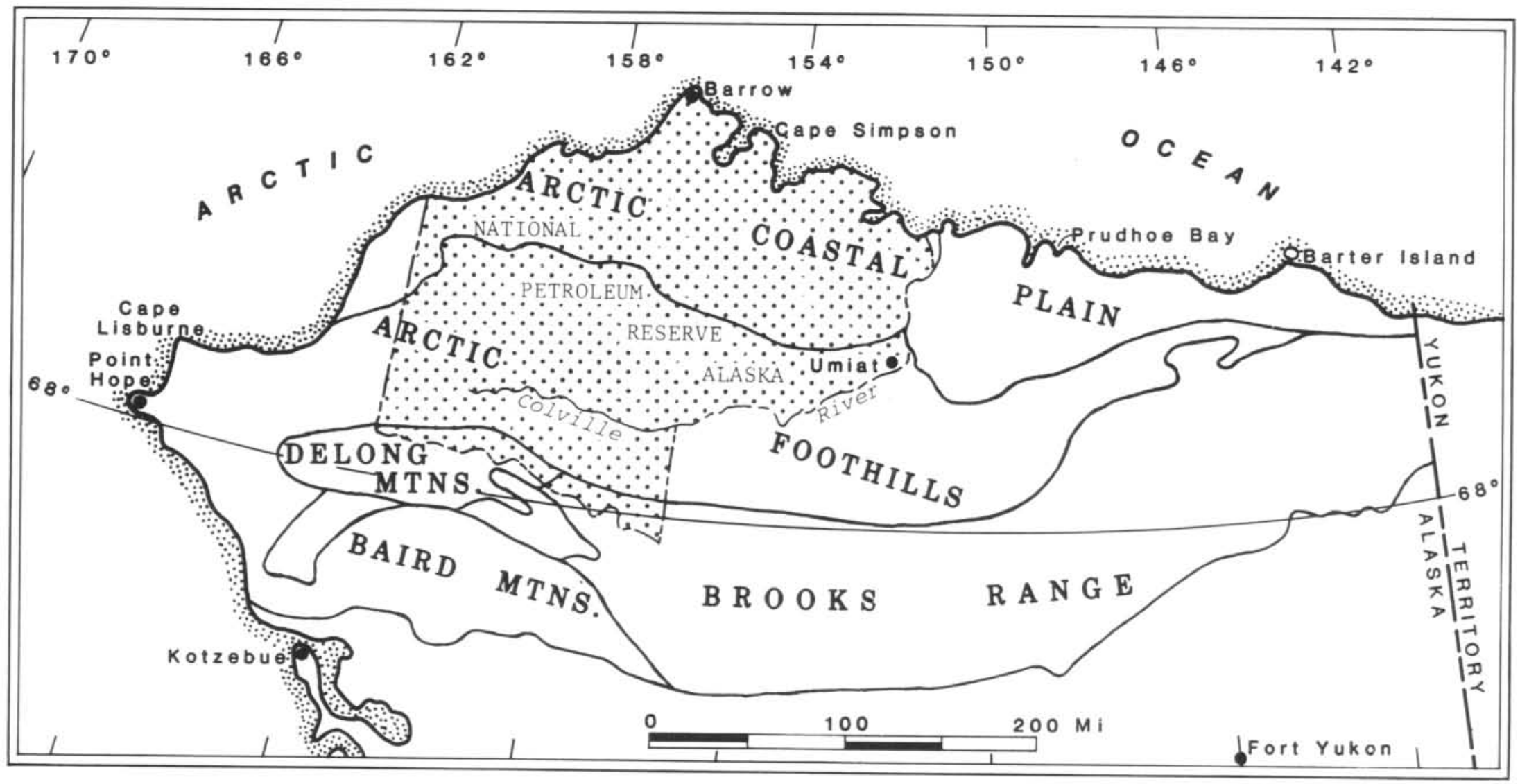




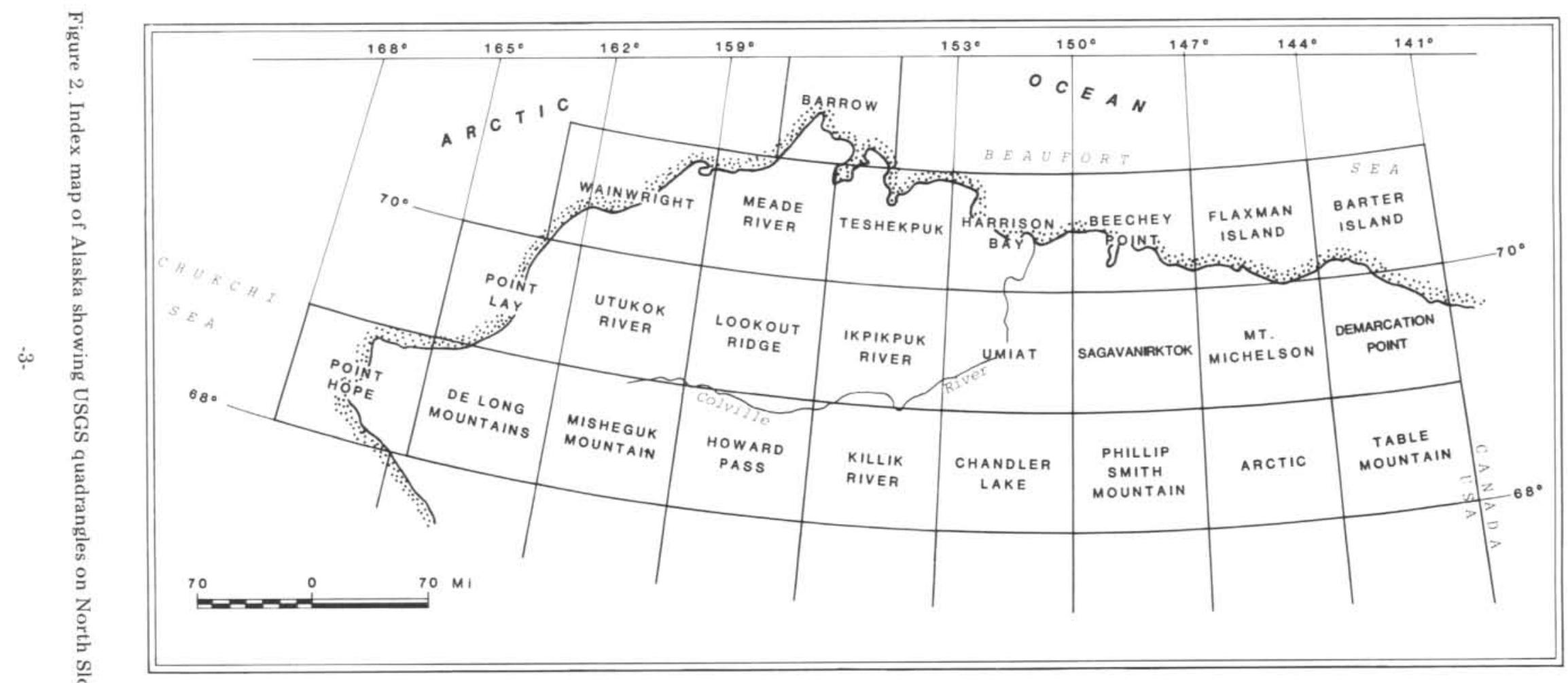




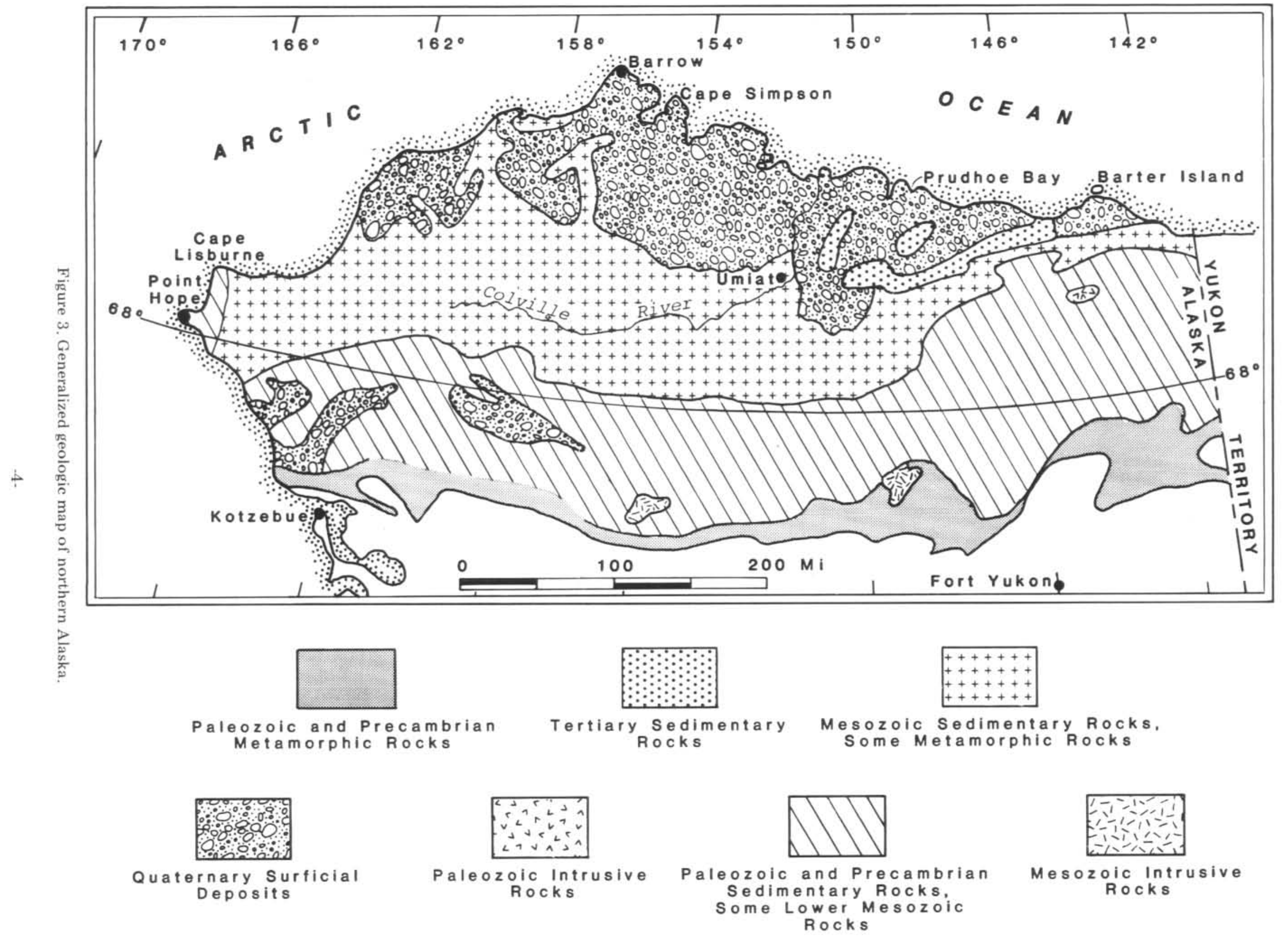


AREA INDEX

Alaska, general

ALEC, 1979; AEIDC, 1976; 1977; 1978; 1979c; 1980; Ahlbrandt, T.S., and Huffman, A.C., 1978; Ahlbrandt, T.S. and others, 1979; Alaska Division of Lands, 1976; Albert, N.R.D., Steele, W.C., and LeCompte, J.R., 1978; Alpha, T.R., and Swenson, Phyllis, 1978; American Petroleum Institute, American Gas Association and Canadian Petroleum Association, 1974; Armstrong, A.K., Mamet, B.L., Brosge, W.P., and Reiser, H.N., 1976; Armstrong, A.K., and Mamet, B.L., 1977;

Barnes, D.F., 1976a; 1976b; 1976c; 1977; Barnes, Peter, and others, 1.977; Barnes, P.W., McDowel1, David, and Reimnitz, Erk, 1978; Bartsch-Winkler, Susan, 1976a; 1976b; 1977a; 1978a; 1978b; 1979; Beikman, H.M., 1978; Beikman, H.M., 1980; Bird, K.J., 1976; Bird, K.J., and Andrews, Jack, 1979; Bird, K.J., and Jordan, C.F., 1976a; 1976b; 1977; Blean, K.M., 1976; 1977; Bottge, K.G., 1975a; Boucher, Gary, 1978;

Carnes, David, 1980; Carter, R.D., Denman, J.M., and Pierpoint, J.G., 1975; Carter, R.D., and others, 1977; Carter, R.D., Mul1, C.G., and Bird, K.J., 1977; Carter, R.D., and others, 1977; Childers, J.M., Kernodle, D., and Loeffler, R., 1978a; 1978b; Churkin, Michael, Jr., 1975; Crane, R.C., and Wiggins, V.D., 1976; Cobb, E.H., 1975; 1976; 1977; 1978; 1979; 1980; Coleman, J.M., 1976; Coury, A.B., Hendricks, T.A., and Tyler, T.F., 1978; 1979;

Detterman, R.L., and Dutro, J.T., 1977;

Feulner, A.J., and Reed, K.M., 1977; Ficke, E.R., and Ficke, J.F., 1977; Fraser, G.S., 1977; Fraser, G.S., and Clarke, R.H., 1976; French, H.M., 1976 ;

Gerin, Marybeth, and Alpha, T.R., 1979; Goldthwait, R.P., 1974; Grantz, Arthur, and others, 1976; Grantz, Arthur, and Eittreim, S.L., 1977; 1979; Crantz, Arthur, Holmes, M.L., and Kososki, B.A., 1975; Gryc, George, Mu11, C.G., and Tailleur, I.L., 1978;

Hackett, S.W., and Laird, G.M., 1977; Hartman, C.W., and Finch, S.G., 1977; Herrera, R.C., 1977; 1978; Hiles, R.M., and others, 1975;

Johnson, K.M., ed., Jones, B.C., 1979, 1980; 1978; Jones, S.H., 1978; Kinney, D.M., and Shelton, J.W., eds., 1976; Larminie, F.G., 1977;

Mayfield, C.F., and others, 1978; McGee, D.L., and O'Connor, K.M., 1975; McIntosh, W.L., and Eister, M.F., 1978; Miller, B.M., and others, 1975; Mowatt, T.C., and Naidu, A.S., 1974; Mu11, C.G., 1979; Mul1, C. G., and Tailleur, I. L., 1977;

Nauman, J.W., and Kernodle, D.R., 1976; Nelson, G.L., 1977; Nummeda1, Dag, and others, 1978; 011 and Gas Journal, 1975g; 1977e; 1979b; 1980n; 1980h; Owens, E.H., 1977;

Patterson, S.O., and Harris, J.R., 1978; Patton, W.W., Jr., and Tailleur, I.L., 1977; Puchtler, Bertold, Reid, Barry, and Christianson, Conrad, 1976 ; 
Alaska, general (cont'd.)

Reimnitz, Erk, and Maurer, D.K., 1978; Roedick, C.A., 1979; Koehler, H.W., and Stickler, G.D., 1979, Rowett, C.L., 1975;

Sainsbury, C.L., and Bloomstein, Edward, 1977; Sando, W.J., 1974; Schoennage1, F.H., 1977; Scott, K.M., 1978; 1979; She11, 1978; Short, A.D., and Wiseman, W.J., Jr., 1975; Simon, R.B., and others, 1978; Singletary, M.K., 1978; Sloan, C.E., 1977; Sloan, C.E., and Snyder, R.F., 1978; Sloan, C.E., Trabant, Vennis, and Glude, William, 1978; State of Alaska 1978; Sweeney, J.F., and others, 1978;

Tailleur, I.L., and Brosge, W.P., 1976; Tailleur, I.L., and Pessel, G.H., 1976; Tectonophysics, 1975; Triplehorn, D.M., 1976;

U.S. Bureau of Mines, 1975, 1977, 1978; U.S. Department of Energy, 1979; U.S. Geological Survey, 1974b; 1975b, 1976b, 1978; U.S. Senate, 1974;

Walker, F.K., 1975; Wanek, A.A., 1974; Witten, Wesley, 1978; Wood, G.V., and Armstrong, A.K., 1975;

Yount, M.E., ed., 1975;

Alaska, arctic

Armstrong, A.K., and Bird, K.J., 1976a; 1976b; Se11kregg, L.L., 1975; WoodwardClyde Consultants, 1976; 1980a; 1980b;

Alaska, northern

AEIDC, 1979a; Alaska Geological Society Newsletter, 1978; Boucher, Gary, 1977; Carlson, R.F., and Fox, P.M., 1976; Collins, R.J., 1974;

Elachi, C., and Bryan, M.L., 1976; Furniss, R.A., and Ward, D.L., 1976; Grantz, Arthur, and Kirschner, C.E., 1976; Ha11, D.K., and Bryan, M.L., 1977, Hopkins, D.M., McDougall, K., and Nelson, R.E., 1978; Joyce, M.K., 1979; Kent, Alan, 1977;

Lagoe, M.B., 1978; Lynch, D.F., Johanson, N.I., and Lambert, C., Jr., and others, 1976; Lowell, J.D., 1976; Naidu, A., and Mowatt, T.C., 1976; Newman, G.E., Mu11, C.G., and Watkins, N.D., 1977; Northern Engineering Services Co., Ltd., 1975;

Oceanographic Institute of Washington, 1979; 0il and Gas Journal, 1975b; 1975c;1975d; 1976b; 1977g; 1977h; 1978; 1979f; 1980e; 1980f; 1980h; 1980i; Patton, W.W., Jr., Tailleur, I.L., Brosge, W.P., and Lanphere, M.A., 1977; Petroleum Engineer, 1974; 
Alaska, northern (cont'd.)

Schindler, J., and Walker, H.J., 1975; Scnoennagel, F.H., 1977; Sobczak, L.W., 1978; Still, P.J., 1980; Tailleur, I.L., and Brosge, W.P., 1975; Tedrow, J.C.F., 1977; Van de Kamp, P.C., 1979; VanDyke, W.P., 1980; Ward, D.L., and Peterson, L.A., 1976; Weiss, H.V., and others, 1974;

Alaska, northeastern

Armstrong, A.K., and Mamet, B.L., 1974, 1978; Bird, K.J., and Jordan, C.F., 1977b; Biswas, N.N., Gedney, L.D., and Huang, P., 1977; Detterman,, R.L., 1974; Gedney, L.D., Biswas, N.N., and Huang, P., 1977; Lyle, W.M., Palmer, I.F., Jr., Bolm, J.G., and Maxey, L.R., 1980; $0 i 1$ and Gas Journal, 1977c; Wilson, J.M., 1977;

Alaska, northwestern

Callahan, J.E., 1975;

Arctic region

Coles, R.L., Hannaford, W., and Hanes, G.V., 1978; Holmgran, B., Benson, C., and Weller, G., 1975; McIvor, D.K., and Gryc, George, 1975; Sweeney, F.J., ed., 1978; west, G.C., 1976; Westmiller, R.J., and Forsyth, D.A., 1978;

Williams, P.J., 1979; Wor1d Petroleum Congress, 1975;

Arctic National Wildlife Range

Kososki, B.A., Reiser, H.N., Cavit, C.D., and Detterman, R.L., 1978;

Mu11, C.G., and Kososki, B.A., Undated; Oil and Gas Journal, 1979e; 1980j;

Arctic Ocean

Clark, D.L., 1975; Grantz, Arthur, and Dinter, D.A., 1980; Grantz, Arthur, May, S.D., Rupert, J.P., and Whitney, O.T., 1977a; Gramberg, I.S., and Kulakov, Yu, N., 1975; Herman, Yvonne, and Hopkins, D.M., 1980;

Beaufort Sea

Aagaard, K., and Haugen, D., 1977; Alaska Department of Natural Resources, 1979; Amoco Production Co., 1975; Arctec, Inc., 1978; Barnes, P.W., Reimnitz, Erk, and Drake, D.E., 1976a; Boucher, Gary, 1979;

Chamberlain, Edwin, 1978; Chin, H., 1980; Eittreim, S., Grantz, Arthur, and Greenberg, J., 1979; England, J.M., and Bruggers, D.E., 1979; Environmental Research and Technology, 1976; 
Beaufort Sea, (cont'd.)

Grantz, Arthur, and others, 1980; Greenberg, Johathan, Hart, P.E., and Grantz, Arthur, 1980; Gulf Research and Development Co., 1980; Harrison, G.R., 1980; Hasegawa, H.S., Cho, C.W., and Basham, P.W., 1979; Henry, R.F., 1975; Henry, R.F., and Heaps, N.S., 1976; Hopkins, D.M., 1979;

Journal of Geophysical Research, 1975; Kovacs, A., 1978; Kovacs, A., and Mellor, M., 1974; Lewellen, R.I., 1974; Mangarella, P., Chin, H., and Niedoroda, A., 1979; Mertz, R.W., Brooks, L.D., and Lansley, R.M., 1979; Meyers, H., 1977; Mountain, D.G., 1974; Munga11, J.C.H., Whitaker, R.E., and Pace, S.D., 1979;

Oceanographic Services Inc., 1976; 1978a; 1978b; 1979a; 1979b; 1980a; 1980b; 1980c; 1980d; 1980e; Oceanweather, Inc., and Sea Ice Consultants, Inc., 1979; Oil and Gas Journal, 1975f; 1979h; 1980g; 1980i; 1980o; 1980p;

Pelletier, B., 1974; Reed, J.C., and Slater, J.E., eds., 1974; Reimnitz, Erk, and Dunton, K., 1979; Rogers, J.C., 1977; 1978; Rogers, J.C., and Morack, J.L., 1976;

Scott, W.R., 1979; Sellman, P.V., 1977; Sellman, P.V., and Chamberlain, E.J., 1979; Shaw, D.G., Smith, E.R., and McIntosh, D.J., 1977; Shearer, G.B., and Miller, D.L., 1979; Sheils, M., and others, 1979; Stringer, W.J., 1976;

Time Magazine, 1979; U.S. Bureau of Land Management, 1978; U.S. Geologica1 Survey, 1979; U.S. News, 1979;

Weller, G., Norton, D.W., and Johnson, T., eds., 1977; Wilson, Howard, 1979; Wilson, H.M., 1979, 1980; Yorath, C.J., Parker, E.R., and Class, D.J., 1975;

Beaufort Sea, continental margin

Grantz, Arthur, and Eittreim, S.L., 1979;

Beaufort Sea, continental shelf

Aagaard, 1976; Barnes, P.W., Reimnitz, Erk, and Drake, D.E., 1976b; Echols, R.J., 1974; Eittreim, S., and Grantz, A., 1977; 1979a; Hopkins, D.M., and Hartz, R.W., 1978a; 1978c; Naidu, A., and Mowatt, T.C., 1974; Reimnitz, Erk, and Barnes, P.W., 1974; Reimnitz, Erk, Barnes, P.W., Toimil, L.J., and Harden, D., 1976; Roedick, C.A., 1974;

\section{Beaufort-Chukchi Sea}

Aagaard, K., ed. 1978; Ah1nas, K., and Wendler, G., 1979; Barry, R.G., Monatz, R.E. and Rogers, J.C., 1979; Hopkins, D.M., ed., 1978; 1979; Hopkins, D.M., and Hartz, R.W., 1978d; 
Beaufort-Chukchi Seas, continental shelf

Barry, R.G., 1977; Brower, W.A., and others, 1977; Grantz, Arthur, Hanna, W.F., and Ruppe1, B.D., 1974; NOAA/BLM, 1978;

Bering-Chukchi Seas

Arctec, Inc., 1980;

Brooks Range

Armstrong, A.K., 1975c; Engineering and Mining Journal, 1977; Mu11, C.G., and Roeder, D., 1978; Nilsen, T.H., Brosge, W.P., Dutro, J.T., and Moore, T.E., 1980; Nilsen, T.H., Moore, T.E., and Brosge, W.P., 1980; Roeder, Deitrich, and Mull, C.G., 1978; U.S. Geological Survey, 1977;

Brooks Range, eastern

Drage, B.T., 1977; Wood, G.V., and Armstrong, A.K., 1975;

Brooks Range, Northern

Lange, I.M., and others, 1980; Metz, P.A., 1979;

Brooks Range, northeastern

Armstrong, A.K., $1975 \mathrm{~b}$;

Brooks Range, northwestern

Nokleberg, W.J., and others, 1979a; 1979b;

Brooks Range, western

Churkin, Michae1, Jr., Nokleberg, W.J., and Huie, Car1, 1979; Geology, 1980;

Canada

Be11, J.S., 1974; Bowerman, J.N., and Coffman, R.C., 1975; Craig, P.C., and McCart, P.J., 1975; Jones, B.E, 1980; Norri.s, D.K., 1978, 1980?; Yorath, C.J., Parker, E.R., and Class, D.J., 1975; Young, F.G., Myhr, D.W., and Yorath, C.J., 1976; 
Chukchi Sea

Eittreim, S., and Grantz, A., 1979b; Eittreim, S., Grantz, A., and Whitney, 0.T., 1977, 1978, 1979; Environmental Research and Technology, 1979;

Garrison, G.R., and Becker, P., 1976; Toimil, L.J., and Grantz, Arthur, 1976;

Toimil, L.J., Reimnitz, Erk, and Grantz, Arthur, 1978;

\section{Chukchi Sea-Arctic Ocean}

Grantz, Arthur, May, S.D., Rupert, J.P., and Whitney, 0.T., 1977b;

Coastal AREA, general

Belon, A.E., Miller, J.M., and Stringer, W.J., 1975; Carlson, R.F., 1977; Carlson, R.F., Norton, W.R., and McDougall, J.C., 1974;

Dingman, S.L., Barry, R.G., and others, in press; Dutro, J.T., Jr., 1979; Everett, K.R., Webber, P.J., and Walker, D.A., and others, 1978;

Harper, J.R., 1978; Harper, J.R., Owens, E.H., and Wiseman, W.J., Jr., 1978; Kane, D.L., Carlson, R.F., and Seifert, R.D., 1975; Kovacs, A., and Sodhi, D.S., 1979; LGL Limited, 1979;

Matthews, J.B., 1978; Naidu, A.S., 1978; Namtvedt, Thomas, Parrish, Scott, Freise, Nancy, 1974; Sellman, P.V., and others, 1975; Short, A.D, 1974; 1975; 1976; 1979; Walker, H.J., 1978; Weller, G., 1976; Weller, M.W., and Derksen, D.V., 1979;

Coastal areas, Beaufort Sea

Barnes, P.W., and Ross, Robin, 1980; Cannon, P.J., 1977; Cannon, P.J., and Rawlinson, S.E., 1978, 1979; Dygas, J.A., and Burre11, D.C., 1975;

Lewellen, R., 1976, 1977; Moritz, R., 1979; Reimnitz, Erk, and Maurer, D.K., 1979a; Rogers, J.C., 1976; Rogers, J.C., and Morack, J.L., 1978;

Short, A.D., Coleman, J.M., and Wright, L.D., 1974; Truett, J.C., 1978; Tucker, R.W., and Burre11, D.C., 1977;

Coastal areas, Alaska, northern

Barnett, D.G., 1976; Brewer, M.C., 1975; Carter, L.D, and Robinson, S.W., 1978a; Everett, K.R., 1979;

Coastal areas, NPRA

Skladel, G.W., 1974; 
Continental Margin

Burk, C.A., and Drake, C.L., eds., 1974; Drummond, K.J., 1974; Grantz, Arthur, and Eittreim, S.L., 1979; Grantz, Arthur, Eittreim, S.L., and Dinter, D.A., 1979 ; Watts, A.B., and Ryan, W.B.F., 1976;

Continental Shelf

Barnes, P.W., and Reimnitz, Erk, 1974; Brooks, L.D., 1974; Bruce, H.E., 1976; Burrel1,D.C., 1976; Burrel1, D.C., Gosnik, T., and Naidu, A.S., and others, 1976; Molnia, B.F., 1979;

Olsen, E.W., Carlson, P.W., and Molnia, B.F., 1980; Reimnitz, Erk, Toimil, L.J., and Barnes, P.W., 1978; Shaw, D.G., 1976; U.S. Bureau of Land Management, 1979a, 1979b; Vigdorchik, M.E., 1980;

Gas Pipeline route

Baker, J.Behlke, C.E., Brooks, C.R., eds., and others, 1976;

Nearshore

Burre11, D.C., chm., 1975; Naidu, A., and Mowatt, T.C., 1974; Stringer, W.J., Barrett, S.A., and Balvin, N., 1977; Weeks, W.F., and Kovacs, A., 1979;

NPRA

Federal Energy Administration, 1976; Ceyer, R.H., 1979; Hickock, D.M., 1976;

National Petroleum Reserve in Alaska Task Force, 1978a, 1978b; 1978c, 1978d, 1978e, 1978f, 1979a, 1979b, 1979c; National Peroleum Reserve in Alaska Work Group 5, 1979;

Oil and Gas Journal, 1975e; 1977d; 1977j; 1979d; 1980b, 1980k; 1980m; Tetra Tech, 1978; 1979; 1980;

U.S. Bureau of Land Management, 1978; U.S. Bureau of Mines, 1977; U.S. Department of the Interior, Office of Minerals, Policy and Research Analysis, 1979;

U.S. Geologica1 Survey, 1978; 1978b; 1978c; 1979c; 1979d; 1979e; 1980a; 1980b; 1980c; 1980d; 1980e; 1980f; 1980g; 1980h; 1980i; U.S. Department of the Navy, 1975; 1977; World 011, 1975;

TAPS Route

Alexander, V.C., and Miller, M.C., 1976; 1977; Childers, J.M., 1974; Committee on Permafrost, 1975; Donovan, N.C., and Singh, S., 1976; Everett, K.R., 1980; 


\section{AREA}

TAPS Route (cont'd.)

Kovacs, A., and Morey, K.M., 1978; Kreig, R.A., and Reger, R.D., 1976;

Mulligan, J.J., 1974; Nauman, J.W., and Kernodle, D.R., 1977; Schmidt, R.A.M., and Champion, C.A., 1976; Skibitzke, H.E., 1974; U.S. National Research Council, National Academy of Sciences, 1975;

Of $f$ shore

Ahlbrandt, T.S., and others, 1979; Barnes, P.W., and Reimnitz, Erk, 1976; Barnes, P.W., and others, 1977; Barnes, P.W. and McDowe11, David, 1978; Barnes, P.W., and Toimil, L.J., 1979; Boucher, Gary, 1976; 1977; Boucher, Gary, and others, 1977;

Campbell, W.J., and Ramseier, R.O., 1978; Chiburis, E.F., and Dehlinger, Peter, 1974; Clark, D.L., 1974; Eittreim, S., Grantz, Arthur, and Whitney, o.T., 1978;

Grantz, Arthur, and others, 1976; Grantz, Arthur, Boucher, Gary, and Whitney, O.T., 1976; Grantz, Arthur, and Eittreim, S.L., 1977; 1979; Grantz, Arthur, Holmes, M.L., and Kososki, A., 1975; Grantz, Arthur, and others, 1975;

Greenberg, Jonathan, Hart, P.k., and Grantz, Arthur, 1979;

Herman, Yvonne, 1977; 1978; Herron, E.M., Dewey, J.F., and Pitman, W.C., III, 1974; Lagoe, 11.B., 1976a; 1976b; 1978; Larson, J.A., 1975; Luepke, Gretchen, 1975; Mann, D.M., 1977; Maurer, D.K., Barnes, H.W., and Reimnitz, Erk, 1978; Mowatt, T.C., and Naidu, A.S., 1974; Mull, C.G., 1979;

Naidu, A.S., and others, 1975; Nelson, Hans, and Creager, J.S., 1977;

Oil and Gas Journal, 1975h; Osterkamp, T.E., and Harrison, W.D., 1976a; 1978a;

1978b; Parsons, Barry, and Sclater, J.G., 1977; Pewe, T.L., 1975; P1att, J. B., 1975; Reimnitz, Erk, and Kodeick, C.A., and Wolf, S.C., 1974, Reinmitz, Erk, Toimil, L.J., and Barnes, P.W., 1977, Reimnitz, and others, 1977; Roedick, C. A., 1979; Ruppe1, B.D., and McHendrie, Graig, 1975;

Schurnacher, G.M., 1976; Sweeney, J.F.and others, 1978; Tailleur, I.L., and Brosge, W.P., 1976; Toimil, L.J., 1978; Toimil, L.J., and Grantz, Arthur, 1976; Yount, M. E., ed., 1975;

Offshore, Beaufort Sea

Rogers, J.C., 1978; 
Arctic quadrangle

Alpha, T.R., and Guerin, Marybeth, 1980;

Barnes, D.E., 1977; Barker, J.C., 1978; Beikman, H.M., and Lathram, E.H., 1976; Bottge, R.G., 1975; Brosge, W.P., and Reiser, H.N., 1976; 1977;

Decker, John, and Kar1, Susan, 1977; Detterman, K.L., 1976a; 1976b; Donovan, T.J., and Tailleur, I.L., 1975; Dutro, J.T., Jr., 1979; Dutro, J.T., Jr., Brosge, W.P., and Reiser, H. N., 1977; Dutro, J.T., Jr., and others, 1979;

Grantz, Arthur, and Mu11, C.G., 1978; Grybeck, Donald, 1977a; 1977b; Grybeck, Donald, and DeYoung, J.H., Jr., 1978; Grybeck, Donald, and others, 1977;

Nilsen, T.H., Moore, T.E., and Brosge, W.P., 1980; Nilsen, and others, 1980;

Oliver, W.A., Jr., Merriam, C.W., and Churkin, Michael, Jr., 1975;

Reiser, H.N., and others, 1979;

Sti11, P.J., 1980;

U.S. Geological Survey, 1979;

Barrow quadrangle

Ah1brandt, T.S., 1979a; 1979b; Alpha, T.R., and Gerin, Marybeth, 1980; Armstrong, A.K., 1974;

Barnes, D.F., 1977; Barnes, P.W., and Garlow, Richard, 1975; Barnes, P.W., and McDowel1, David, 1978; Barnes, P.W., and Reimnitz, Erk, 1976; Barnes, P.W., and others, 1977; Barnes, P.W., and Toini1, L.J., 1979; Beikman, H.M., and Lathram, E.H., 1976; Bird, K.J., and Andrews, Jack, 1979;

Boucher, Gary, 1976; Boucher, Gary, and others, 1977;

Carter, Claire, and Laufeld, Sven, 1975; Carter, R.D., and Lantz, R.J., 1978; 1979; $\mathrm{CH}_{2} \mathrm{M} \mathrm{Hi11,} \mathrm{1976;} \mathrm{Churkin,} \mathrm{Michael,} \mathrm{Jr.,} \mathrm{1975;} \mathrm{Curtis,} \mathrm{S.M.,} \mathrm{and}$ Rossiter, Richard, 1979; Curtis, S.M., and others, 1979;

Decker, John, and Karl, Susan, 1977; Detterman, R.L., 1978; Grantz, Arthur, and others, 1976; Grantz, Arthur, and others, 1980; Greenberg, Johnathan, Hart, P.E., and Grantz, Arthur, 1979;

Harding-Lawson Associates, 1975; Harding-Lawson Associates, and $\mathrm{CH}_{2} \mathrm{M} \mathrm{Hil1,}$ 1979; Harper, J.R., 1978; Hartz, R.W., 1978; Hopkins. D.M., and Hartz, R. W., 1978; Huffman, A.C. and Ahlbrandt, T.S., 1979; Imlay, R.W., 1976;

Johnson, K.M., 1978; Jones, S.H., 1978;

LaBelle, J.C., 1976; Leupke, Gretchen, 1975, McGaw, R.W., Outcalt, S.I., and Ng, E., 1978; Magoon, L.B., and Claypool, G. E., 1978; 1979; 1980; Mann, D.M., 1977; Martin, G.C., and Callahan, J.E., 1978; Moore, B.J., 1976; Moritz, R.1977; 
AREA

Barrow (Cont'd.)

Oil and Gas Journa1, 1977b; Pewe, T.L., 1975; Reimnitz, Erk, Barnes P.W., and Kempa, Edward, 1979; Reimnitz, Erk, and others, 1980; Reimnitz, Erk and Maurer, D. K., 1978a; 1978b; Roedick, C. A., 1979; Rogers, J.C., Harrison, W.D., and Ruppel, B.D., and McHendrie, A. G., 1975; 1976;

Schumacher, G.M., 1976; Shapiro, L.H., and others, ? 1975; Shaw, D.G., Smith, E.R., and McIntosh, D.J., 1977; Short, A.D., and Wright, L.D., 1974; Sloan, Charles, Trabant, Dennis, and Glude, William, 1979; Still, P. J., 1980;

Tasch, P.1979; Toimil, L.J., 1978, Townshend, J.B., 1978; U.S. Geologica1 Survey, 1975; 1979; Williams, J.R., and others, 1977; Williams, J.R., Carter, L.D., and Yeend, W.E., 1978; Witmer, R.J., 1980;

\section{Barter Island}

Alpha, T.R., and Gerin, Marybeth, 1980;

Barnes, D.F., Kososki, B.M., Mayfield, C.F., Ruppel, B.D., Robbins, S.L., and Tailleur, I.L., 1976; 1976; Barnes, P.W.; and Garlow, Richard, 1975; Barnes, P.W., Reimnitz, Erk, Drake, D.E., and Toimil, L.J., 1977; Barnes, P.W., and Toimil, L.J., 1979; Beikman, H.M., and Lathram, E.H., 1976; Bottge, R.G., 1975; Boucher, Gary, 1976; Boucher, Gary, Ruppel, B.D., Chiburis, E.F., and Dehlinger, Peter, 1977; Brosge, W.P., and Reiser, H.N., 1976;

Childers, J.M., Sloan, C.E., Meckel, J.P., and Nauman, J.W., 1977; Craig, P.C., and McCart, P.J., 1975;

Detterman, R.L., Reiser, H.N., Brosge, W.P., and Dutro, J.T., Jr., 1975;

Grantz, Arthur, and others, 1980; Greenberg, Jonathan, Hart, P.E., and Grantz, Atrhur, 1979; Grybeck, Donald, and others, 1977;

Hopkins, D.M., and Hartz, R.W., 1978;

Leupke, Gretchen, 1975;

Magoon, L.B., and Claypool, G.E., 1979; Mast, R.F., McMullin, R.H., Bird, K.J., and Brosge, W.P., 1980; Mowatt, T.C., and Naidu, A.S., 1974; Mu11 C. G., and Kososki, B. A., 1977;

Naidu, A.S., and others, 1975;

Pewe, T.L., 1975;

Ruppe1, B.D., and McHendrie, A.G., 1976;

Schumacher, G.M., 1976; Short, A.D., and Wright, L.D., 1974; 
AREA

Beechey Point quadrangle

AAPG, 1979a; AEIDC, 1980; Ah1brandt, T.S., 1979a; 1979b; Alaska Consultants, Inc, 1978; Alaska Division of Geological and Geophysical Surveys, 1976; Alaska Geological Society, 1977; Alaska Oil and Gas Conservation Commission, 1978; 1980; Albert, N.R.D., 1978; Alpha, T.R., and Gerin, Marybeth, 1980; Armstrong, A.K., 1974; Armstrong, A.K., and Mamet, B.L., 1974;

Barnes, D.F., 1977; Barnes, P.W., and Garlow, Richard, 1975; Barnes, P.W., and McDowel1, David, 1978; Barnes, P.W., McDowe11, David, and Reimnitz, Erk, 1978; Barnes, P.W., and Reimnitz, Erk, 1976; 1979; Barnes, P.W., Reimnitz, Erk, Drake, D.E., and Toimil, L.J., 1977; Barnes, P.W., Reimnitz, Erk, Kempema, Edward, Minkler, Peter, and Ross, Robin, 1980;

Barnes, P.W., Reimnitz, Erk, and Ross, Robin, 1980; Barnes, P.W., Reimnitz, Erk, Smith, Greg, and Melchior, John, 1977; Barnes, P.W., Reimnitz, Erk, Toimil, L.J., and Hill, H.R., 1979; Barnes, P.W., Reimnitz, Erk, Toimil, L.J., Maurer, Douglas, and McDowell, David, 1979; Barnes, P.W., Reimnitz, Erk, and others, 1979; Barnes, P.W., and Toimil, L.J., 1979;

Beikman, H.M., and Lathram, E.H., 1976; Bird, K.J., 1976; 1978a; 1978b; 1978c; Bird, K.J., and Jordan, C.F., 1976; 1977; Blouin, S.E., Chamberlain, E.J., Sellman, , P.V., and Garfield, D.E., 1979; Blouin, S.E., Chamberlain, E.J., Sellman, P.V., and others, 1979;

Bottge, R.G., 1975; Boucher, Gary, 1976; Boucher, Gary, Reimnitz, Erk, and Kempema, Edward, 1980; Boucher, Gary, Ruppe1, B.,D., Chiburis, E.F., and Dehlinger, Peter, 1977; Brown, Jerry, Haugen, R.K., and Parrish, Scott, 1975; Buchan, S.H., 1977; Burre11, D.C., Dygas, J.A., and Tucker, R.W., 1974;

Carter, Claire, and Laufeld, Sven, 1975; Carter, R.D., Mull, C.G., Bird, K.J., and Powers, R.B., 1977; Childers, J.M., Nauman, J.W., Kernodle, D. T., and Doyle, P.F., 1978; Childers, J.M., Sloan, C.E., Meckel, J.P., and Nauman, 1977; Chin, H., Niedoroda, A., and Mangarella, P., 1979; Churkin, Michael, Jr., 1975; Clarke, R.H., 1976; Craig, P.C., and McCart, P.J., 1975;

Dames and Moore, 1980; Decker, John, and Karl, Susan, 1977; Detterman, R.L., 1978; Drahn, R.A., 1976; Dygas, J.A., 1975; Dutro, J.T., Jr., 1979; Ecklemann, W.R., DeWitt, R.J., and Fisher, W.L., 1975, 1976, Environmental Services, Ltd., 1978, Everett, K.R., 1979, Feder, H.M., Shaw, D.G., and Naidu, A.S, 1976, Fraser, G.S., and Clarke, R.H., 1976;

Grantz, Arthur, Barnes, P.W., Dinter, D.A., Lynch, M.B., Reimnitz, Erk, and Scott, E.W., 1980; Grantz, Arthur, Barnes, P.W., Eittreim, S.L., Reimnitz, Erk, Scott, E.W., Smith, R.A., Stewart, George, and Toimil, L.J., 1976; Grantz, Arthur, and Mul1, C.G., 1978; Greenberg, Jonathan, Hart, P. E., and Grantz, Arthur, 1979; Grinder, G.W., Robilard, G.A., and Firth, R.W., Jr., 1977; 1978;

Hardin, Deborah, Barnes, Peter, and Reimnitz, Erk, 1977; Hardy Associates,(1978) Ltd., 1980; Hartz, R.W., Holden, K., Hopkins, D.M., and Shearer, G., 1979; Holder, G.D., Katz, D.L., and Hand, J.H., 1976; Hopkins, D.M., and Hartz, R.W., 1978; Hopkins, D.M., and Robinson, S.W., 1979; Huffman, A.C., and Ahlbrandt, T.S., 1979; -15- 
Beechey Point (cont'd) AREA

Jamison, H.C., Brockett, L.D., and McIntosh, R.A., 1979; Jones, H.P., and Speers, R.G., 1976; Kane, D.L., Rice, E.F., and Carlson, R.F., 1975; LaBelle, J.C., 1976; Lachenbruch, A.H., and Marshal1, B.V., 1977; 1978; Levorsen, J.A., Pesse1, G.H., Carter, R.D., and Tailleur, I.L., 1978a; 1978b; 1978c; Luepke, Gretchen, 1975;

Magoon, L.B., and Claypool, G.E., 1979; Maurer, D.K., Barnes, P.W., and Reimnitz, Erk, 1978; McIntosh, Ron, 1977; Meckel, J.P., 1976; Mowatt, T.C., and Naidu, A.S., 1974;

Naidu, A.S., Burre11, D.C., Hood, D.W., and Dygas, J.A., 1975; Naidu, A., and Mowatt, T.C., 1975; Nelson, G.L., 1976; Nilsen, T.H., Moore, T.E., Dutro, J.T., Jr., Brosge, W.P., and Orchard, D.M., 1980; Niedoroda, A., Chin, H., and Mangarella, P., 1979;

Offshore, 1975a; 1975b; 1975c; 1975d; 1977a; 1977b; 1977c; Oil and Gas Journal, 1975a; 1975i; 1976a; 1979a; 1979c; 1980a; 1980c; Osterkamp, T.E., and Harrison, W.D., 1976b;

Page, F.W., and Iskandar, I.K., 1978; Parkinson, R.J., 1978; PBUWTF, 1979; Pessel, G.H., Tailleur, I.L., and Bird, K.J., 1978a; 1978b; 1978c; 1978d; Pesse1, G.H., Tailleur, I.L., and Levorsen, J.A., 1978; Peterson, L.A., 1979; Peterson, Laurence A., 1979; Petroleum Engineer, 1980; Pewe, T.L., 1975; Powel1, T.G.Cook, P.J., and McCurdy, D.M., 1975;

Reinnitz, Erk, 1976; Reimnitz, Erk, Barnes, P.W., and Kempena, Edward, 1979; Reimnitz, Erk, Barnes, P.W., and Maurer, Douglas, 1979; Reimnitz, Erk, Kempema, Edward, Ross, Robin, and Minkler, Peter, 1980; Reimnjtz, Erk, Maurer, D.K., 1978a; 1978b; Reimnitz, Erk, Maurer, D.K., Barnes, P.W., and Toimil, L.D., 1977 ;

Reimnitz, Erk, and Ross, Robin, 1979; Reimnitz, Erk, Ross, Robin, and Barnes, P.W., 1980; Ritchie, W., and Walker, H.V., 1974; Rogers, J.C., 1977b; Rogers, J.C., and Morack, J.L., 1980; Rogers, J.C., and Morack, J.R., 1978; Rodeick, C.A., 1979; Ruppel, B.D., and McHendrie, A.G., 1976;

Schoennage1, F.H., 1977; Schumacher, G.M., 1976; Scott, K.M., 1978; Shaw, D.G., Smith, E.R., and McIntosh, D.J., 1977; Short, A.D., and Wiseman, W.J., Jr., 1975; Short, A.D., and Wright, L.D., 1974; Sloan, C.E., Zenone, Chester, and Mayo, L.R., 1975; 1976; Smith, E.R., 1976; Sti1l, P.J., 1980;

Tailleur, I.L., Bird, K.J., and Engwicht, S.E., 1978; Tailleur, I.L., and Engwicht, S.E., 1978a; 1978b; 1978c; Tailleur, I.L., Pessel, G.H., and Engwicht, S.E., 1978; Tailleur, I.L., Pessel, G.H., Levorsen, J.A., and Engwicht, S.E., 1978 ;

U.S. Army Corps of Engineers, 1980; U.S. Bureau of Land Management, 1974; U.S. Geological Survey, 1975; 1976; 1977; 1978; 1979; U.S. Senate, 1974; Updike, R.G., and Howland, M.D., 1979;

Van Poolen, H.K., and Associates, 1974; Wadham, D.H., Lamprecht, D.E., and Mrosousk! Ivan, 1979; Walker, D.A., and others, 1980; Walker, H.J., 1974; 1976a; 1976b; World 0il, 1975a; World Petroleum Congress, 1975; 
AREA

Chandler Lake

Ahlbrandt, T.S., 1979a; 1979b; Ahlbrandt, T.S., Huffman, A.C., Jr., Fox, J.E., and Pasternack, Ira, 1979; Alpha, T.R., and Gerin, Marybeth, 1980; Armstrong, A.K., 1975c; Armstrong, A.K., and Manet, C.L., 1977a; 1977b;

Barnes, D.F., 1977; Bartsch-Winkler, Susan, 1979; Beikman, H.M., and Lathram, E.H., 1976; Bottge, R.G., 1975; Brosge, W.P., and Armstrong, A.K., 1977;

Brosge, W.P., Reiser, H.N., Dutro, J.R., Jr., and Nilsen, T.H., 1979;

Cobb, E.H., 1975;

Decker, John, and Karl, Susan, 1977; Degenhart, C.E., Griffis, R.J., McOuat, J.F., and Bigelow, C.G., 1978; Detterman, R.L., 1978; Donovan, T.J., and Tailleur, I.L., 1975; Dutro, J.T., Jr., 1979;

Fox, J.E., and Lambert, P.W., Pitman, J.K., and wu, C.H., 1979;

Grybeck, Donald, 1977; Grybeck, Donald, Beikman, H.M., Brosge, W.P., Tailleur I.L., and Mul1, C.G., 1977; Grybeck, Donald, and DeYoung, J.H., Jr., 1978; Glude, W.J., and Sloan, C.E., 1980;

Hamilton, T.D., 1979a; 1979b; 1980; Hardin, Deborah, Barnes, P.W., and Reimnitz, Erk, 1977; Huffman, A.C., and Ahlbrandt, T.S., 1979; Hunter, R.E.., and Fox, J.E., 1976 ;

ImI.ay, R.W., 1976;

Kaiser Engineers, Inc., 1977;

Lawver, L.S., Lachenbruch, A.H., and Moses, T.H., Jr., 1979;

Mu11, C.G., 1979; Mul1, C.G., Tailleur, I.L., Mayfield, C.F., and Pessel, G.H., 1976;

Nilsen, T.H., Moore, T.E., and Brosge, W.P., 1980; Nilsen, T.H., Moore, T.E., Dutro, J.T., Jr., Brosge, W.P., and Orchard, D.M., 1980;

Pewe, T.L., 1975; Platt, J.B., 1975;

Reiser, H.N., Brosge, W.P., Dutro, J.T., Jr., and Detterman, R.L., 1979;

Rowett, C.L., 1975;

Schoennage1, F.H., 1977; Scott, R.A., and Smiley, C.J., 1979; Sloan, C.E., Trabant, Dennis, and Glude, W.G., 1979; Sti11, P.J., 1980;

U.S. Bureau of Mines, Alaska Field Operations Center, 1978; 1979; U.S. Geological Survey, $1976 ; 1977$; 
De Long Mountains

Ahlbrandt, T.S., 1979a; 1979b; Ahlbrandt, T.S., Huffman, A.C., Jr., Fox, J.E., and Pasternack, Ira, 1979; Armstrong, A.K., 1975; Armstrong, A.K., and Mamet, B.L., 1977;

Barnes, D.F., 1977; Bartsch-Winkler, Susan, 1979; Beikman, H.M., and Lathram, E.H.., 1976; Bird, K.J., and Andrews, Jack, 1979;

Callahan, J.E., and Sloan, C.E., 1978; Childers, J.M., Kernodle, D.R., and Loeffler, R.M.,, 1979; Churkin, Michael, Jr., Huie, Car1, Mayfield, C.F., and Nokleberg, W.J., 1978; Churkin, Michael, Jr., Mayfield, C.F., Theobald, P.K., Barton, Harlan, Nokleberg, W.J., Winkler, G.R., and Huie, Car1, 1978; Cobb, E.H., 1975;

Decker, John, and Kar1, Susan, 1977; Degenhart, C.E., Griffis, R.J., McOuat, J.F., and Bigelow, C.G., 1978; Detterrman, R.L., 1978; Donovan, T.J., and Tailleur, I.L., 1975; Dutro, J.T., Jr., 1979;

Ellersieck, Inyo, Curtis, S.M., Gruzensky, A.L., Mayfield, C.F., and Tailleur, I.L., 1980;

Grybeck, Donald, 1977; Grybeck, Donald, Beikman, H.M., Brosge, W.P., Tailleur, I.L., and Mull, C.G., 1977; Grybeck, Donald, and Nokleberg, W.J., 1979;

Huffman, A.C., Jr., 1979; Huffman, A.C., and Ahlbrandt, T.S., 1979;

Kaiser Engineers, Inc., 1977;

Mayfield, C.F., Curtis, S.M., Ellersieck, I.F., and Tailleur, I.L., 1979;

Mul1, C.G., 1979; Mul1, C.G., Tailleur, I.L., Mayfield, C.F., and Pessel, G.H., 1976;

Nilsen, T.H., Moore, T.E., Dutro, J.T., Jr., Brosge, W.P., and Orchard, D.M., 1980; Nokleberg, W.J., and Winkler, G.R., 1978a; 1978b; 1978c;

Oliver, W.A., Jr., Merriam, C.W., and Churkin, Michael, Jr., 1975;

Pesse1, G.H., Levorsen, J.A., and Tailleur, I.L., 1978a; 1978b; 1978c; 1978d; 1978e; Pesse1, G.H., and Tailleur, I.L., 1978; Pewe, T.L., 1975; Plahuta, J.T., 1978; Plahuta, J.T., Lange, I.M., and Jansons, Uldis, 1978; Platt, J.B., 1975 ;

Roeder, Dietrich, and Mull, C.G., 1978;

Schumacher, G.M., 1976; Scott, R.A., and Smiley, C.J., 1979; Sliter, W.V., 1979; Sti11, P.J., 1980;

Tailleur, I.L., Ellersieck, I.F., and Mayfield, C.F., 1977; Theoba1d, P.K., and Barton, H.N., 1978;

U.S. Bureau of Mines, Alaska Field Operations Center, 1978a; 1978b; 1979; U.S. Geological Survey, 1974;

Zimmerman, Jay and Soustek, P.G., 1979; 


\section{Demarcation Point}

Alpha, T.R., and Gerin, Marybeth, 1980; Armstrong, A.K., 1975a; Armstrong, A.K., and Mamet, B.L., 1975; 1977;

Barker, J.C., 1978; Barnes, D.F., 1977; Barnes, D.F., Kososki, B.M., Mayfield, C.F., Ruppel, B.D., Robbins, S.L., and Tailleur, I.L., 1976; Barnes, P.W., and Toimil, L.J., 1979; Beikman, E.M., and Lathram, E.H., 1976; Bottge, R.G., 1975; Boucher, Gary, 1.976; Brosge, W.P., and Reiser,

H.N., 1976;

Childers, J.M., Sloan, C.E., Mecke1, J.P.and Nauman, J.W., 1977; Cobb, E.H., 1975; Craig, P.C., and McCart, P.J., 1975; Wood, G.V., and Armstrong, A.K., 1975;

Decker, John, and Karl, Susan, 1977; Detterman, R.L., 1976; 1978; Detterman, R.L., Reiser, H.N., Brosge, W.P., and Dutro, J.T., Jr., 1975; Donovan, T.J., and Tailleur, I.L., 1975; Dutro, J.T., Jr.1979;

Grantz, Arthur, and Mull, C.G., 1978; Greenberg, Jonathan, Hart, P.E., and Grantz, Arthur, 1979; Grybeck, Donald, 1977a; 1977b; Grybeck, Donald, Beickman, H.M., Brosge, W.P., Tailleur, I.L., and Mull, C.G., 1977; Grybeck, Donald, and Nokleberg, W.J., 1979;

Hardin, Deborah, Barnes, Peter, and Reimnitz, Erk, 1977; Hopkins, D.M, and Hartz, R.Q., 1978;

Imlay, R.W., 1976

Kososki, B.A., Reiser, H.N., Cavit, C.D., and Detterman, R. L., 1978;

Lyle, W.M., Palmer, I.F., Bolm, J.G., and Maxey, L.R., 1980;

Magoon, L.B., and Claypool, G.E., 1979; Mast, R.F., McMullin, R.H., Bird, K.J., and Brosge, W.P., 1980; Meckel, J.P., 1976; MulI, C.G., and Kososki, B.A., 1977;

Nilsen, T.H., Moore, T.E., and Brosge, W.P., 1980; Nilsen, T.H., Moore, T.E., Dutro, J.T., Jr., Brosge, W.P., and Orchard, D.M., 1980;

Palmer, I.F., Jr., Bolm, J.G., Maxey, L.R., and Lyle, W.M., 1979; Pewe, T.L., 1975;

Reiser, H.N., Brosge, W.P., Detterman, R.L., and Dutro, J.T., Jr., 1978; Reiser, H.N., Norris, D.K., Dutro, J.T., Jr., and Brosge, W.P., 1978; Rowett, C.L., 1975; Rupppe1, B.D., and McHendrie, A.G., 1976;

Sable, E.G., 1977; Schumacher, G.M., 1976; Short, A.D., and Wright, L.D., 1974; Sti11, P.J., 1980;

U.S. Geological Survey, 1976; 1979; 
Flaxman Island quadrangle

Albert, N.R.D., 1978; Alpha, T.R., and Gerin, Marybeth, 1980; Armstrong, A.K., 1974;

Barnes, D.F., 1977; Barnes, D.F., Kososki, B.M., Mayfield, C.F., Ruppel, B.D., Robbins, S.L., and Tailleur, I.L., 1976; Barnes, P.W., and Garlow, Richard, 1975; Barnes, P.W., and McDowell, David, 1978; Barnes, P.W., and Reimnitz, Erk, 1976; Barnes, P.W., Reimnitz, Erk, Drake, D.E., and Toimil, L.J., 1977; Barnes, P.W., Reimnitz, Erk, Kempema, Edward, Minkler, Peter, and Ross, Robin, 1980; Barnes, P.W., and Toimil, L.J., 1979;

Beikman, H.M., and Lathram, E.H., 1976; Bird, K.J., 1976; 1978a; 1978b; Bird, K.J., and Jordan, C.F., 1977; Bottge, R.G., 1975; Boucher, Gary, 1976; Boucher, Gary, Ruppel, B.D., Chiburis, E.F., and Dehlinger, Peter, 1977; Brosge, W.P., and Reiser, H.N., 1976;

Carter, R.D., Mull, C.G., Bird, K.J., and Powers, R.B., 1977; Childers, J.M., Sloan, C.E., Meckel, J.P., and Nauman, J.W., 1977; Craig, P.C., and McCart, P.J., 1975;

Decker, John, and Kar1, Susan, 1977; Detterman, K.L., 1978;

Grantz, Arthur, Barnes, P.W., Dinter, D.A., Lynch, M.B., Reimnitz, Erk, and Scott, E.W., 1980; Grantz, Arthur, Barnes, P.W., Eittreim, S.L., Reimnitz, Erk, Scott, E.W., Smith, R.A., Stewart, George, and Toimil, L.J., 1976; Grantz, Arthur, and Mu11, C.G., 1978; Greenberg, Jonathan, Hart, P. E., and Grantz, Arthur, 1979; Grybeck, Donald, Beikman, H.M., Brosge, W.P., Tailleur, I.L., and Mull, C.G., 1977;

Hardin, Deborah, Barnes, P.W., and Reimnitz, Erk, 1977; Hartz, R.W., Holden, K., Hopkins, D.M., and Shearer, G., 1979; Hopkins, D.M., and Hartz, R.W., 1978; Hopkins, D.M., and Robinson, S.W., 1979;

Kososki, B.A., Reiser, H.N., Cavit, C.D., and Detterman, R. L., 1978;

Levorsen, J.A., Pesse1, G.H., Carter, R.D., and Tailleur, E.L., 1978a; 1978b; Luepke, Gretchen, 1975;

Mast, R.F., McMullin, R.h., Bird, K.J., and Brosge, W.P., 1980; Mowatt, T.C., and Naidu, A.S., 1974;

Naidu, A.S., Burre11, D.C., Hood, D.W., and Dygas, J.A., 1975;

Oil and Gas Journal, 1977i;

Pesse1, G.H., Levorsen, J.A., and Tailleur, I.L., 1978a; 1978b; 1978c; 1978d;

1978e; Pessel, G.H., and Tailleur, I.L., 1978; Pessel, G.H., Tailleur, I. L., and Bird, K.J., 1978a; 1978b; 1978c; 1978d; Pesse1, G.H., Tallleur, I. L., and Levorsen, J.A., 1978; Peterson, L.A., 1979, Pewe, T.L., 1975; 
Reimnitz, Erk, 1976; Reimnitz, Erk, Barnes, P.W., and Kempena, Edward, 1979; Reimnitz, Erk, Barnes, P.W., and Maurer, Douglas, 1979; Reimnitz, Erk, and Maurer, D.K., 1978; Reimnitz, Erk, Maurer, Douglas, Barnes, P.W., and Toimil, L.J., 1977; Reimnitz, Erk, and Ross, Robin, 1979; Roedick, C.A., 1979; Ruppe1, B.D., and McHendrie, A.G., 1976;

Schumacher, G.M., 1976; Sti11, P.J., 1980;

Tailleur, I.L., Bird, K.J., and Engwicht, S.E., 1978; Tailleur, I.L., and Engwicht, S.E., 1978a; 1978b; 1978c; Tailleur, I.L., and Pessel, G.H., and Engwicht, S.E., 1978; Tailleur, I.L., Pessel, G.H., Levorsen, J.A., and Engwicht, S.E., 1978;

U.S. Geological Survey, 1979;

\section{Harrison Bay quadrangle}

Ah1brandt, T.S., 1979a; 1979b; Albert, N.R.D., 1978; Alpha, T.R., and Gerin, Marybeth, 1980; Armstrong, A.K., 1974;

Barnes, D.F., 1977; Barnes, P.W., and Garlow, Richard, 1975; Barnes, P.W., and McDowel1, David, 1978; Barnes, P.W., McDowe11, David, and Reimnitz, Erk, Barnes, P.W., and Reimnitz, Erk, 1976; 1979; Barnes, P.W., Reimnitz, Erk, Drake, 1).E., and Toimil, L.J., 1977; Barnes, P.W., Reimnitz, Erk, Kempema, Edward, Minkler, Peter, and Ross, Robin, 1980; Barnes, P.W., Reimnitz, Erk, and Ross, Robin, 1980; Barnes, P.W., Reimitz, Erk, Toimil, L.J., 1977;

Beikman, H.M., and Lathram, E.H., 1976; Bird, K.J., 1976; 1978a; 1978b; 1978c; Bird, K.J., and Andrews, Jack, 1979; Bird, K.J., Connor, C.L.., Tailleur, I.L., Silberman, M.L., and Christie, J.L., 1978; Bird, K.J., and Jordan, C.F., 1976; 1977; Boucher, Gary, 1976; Boucher, Gary, Ruppe1, B.D., Chiburis, E.F., and Dehlinger, Peter, 1977;

Carter, L.D., and Galloway, J.P., 1979a; 1979b; Carter, L.D., Marincovich, Loule, Jr., Brouwers, E.M., and Forester, R.M., 1979; Carter, L.D., Repenning, C.A., Marincovich, L.N., Hazel, J.E., Hopkins, D.M., McDougal1, Kristin, and Naeser, C.W., 1977; Carter, L.D., and Robinson, S.W., 1978; Carter, R.D., Mu11, G.C., Bird, K.J., and Powers, R.B., 1977;

Childers, J.M., Kernodle, I).R., and Loeffler, R.M., 1979; Childers, J.M., Sloan, C.E., Meckel, J.P., and Naunan, J.W., 1977; Claypool, G.E., and Magoon, L.B., 1980a; 1980b; Curtis, S.M., and Rossiter, Richard, 1979; Curtis, S.M., Rossiter, Richard, Ellersieck, I.F., Mayfield, C.F., and Tailleur, I.L., 1979;

Decker, John, and Kar1, Susan, 1977; Detterman, R.L., 1978; Dutro, J.T., Jr., 1979 ;

Galloway, J.P., and Carter, L.D., 1978; Grantz, Arthur, Barnes, P.W., Eittreim, S.L., Reimnitz, Erk, Scott, E.W., Smith, R.A., Stewart, George, and Toimil, J.G., 1976; Grantz, Arthur, Barnes, P.W., Dinter, D.A., Lynch, M.B., Reimnitz, Erk, and Scott, E.W., 1980; Greenberg, Johnathan, Hart, P.E., and Grantz, Arthur, 1979; 
Harrison Bay quadrangle (cont'd.)

Hardin, Deborah, Barnes, Peter, and Reimnitz, Erk, 1977; Hartz, R.W., 1978; Hopkins, D.M., and Hartz, R.W., 1978; Hopkins, D.M., and Robinson, S.W., 1979; Huffman, A.C., and Ahlbrandt., T.S., 1979;

Johnson, K.M., 1978;

Kachadoorian, Reuben, Crory, F.E., and Berg, R.L., 1979; Kaiser Engineers, Inc., 1977; Kososki, B.A., and Anderson, R.C., 1977;

LaBelle, J.C., 1976; Levorsen, J.A., Pessel, G.H., Carter, R.D., and Tailleur, I.L., 1978a; 1978b; Luepke, Gretchen, 1975;

Magoon, L.B., and Claypool, G.E., 1979; 1980a; 1980b; 1980c; 1980d; Martin, G.C., and Callahan, J.E., 1978; Maurer, D.K., Barnes, P.W., and Reimnitz, Erk, 1978; Mowatt, T.C., Naidu, A.S., and Veach, Namok, 1974;

Naidu, A.S., Burrel1, D.C., Hood, D.W., and Dygas, J.A., 1975; Naidu, A.S., and Mowatt, T.C., 1974; Nemeth, D.F., 1977;

011 and Gas Journal, 1979c;

Pessel, G.H., Levorsen, J.A., and Tailleur, I.L., 1978a; 1978b; 1978c; 1978d; 1978e; Pesse1, G.H., and Tailleur, I.L., 1978; Pesse1, G.H., Tailleur, I.L., and Bird, K.J., 1978a; 1978b; 1978c; 1978d; 1978e; Peterson, L.A., 1979; Pewe, T.L., 1975;

Reimnitz, Erk, Barnes, P.W., and Kempema, Edward, 1979; Reimnitz, Erk, Barnes, P.W., and Maurer, Douglas, 1979; Reimnitz, Erk, Barnes, P.W., Toimil, L.J., and Melchior, John, 1977; Reimnitz, Erk, Kempema, Edward, Ross, Robin, and Minkler, Peter, 1980; Reimnitz, Erk and Maurer, D.K., 1978a; 1978b; Reimnitz, Erk, Maurer, Doug, Barnes, Peter, and Toimil, L.J., 1977; Reimnitz, Erk, and Ross, Robin, 1979;

Repenning, C.A., 1978; Ritchie, W., and Walker, H.V., 1974; Rodeick, C.A., 1979; Ruppe1, B.D., and Mcllendrie, A.G., 1976;

Schumacher, G.M., 1976; Short, A.D., and Wiseman, W.J., Jr., 1975; Sloan, Charles, Trabant, Dennis, and Glude, William, 1979; Still, P.J., 1980;

Tailleur, I.L., Bird, K.J., and Engwicht, S.E., 1978; Tailleur, I.L., and Engwicht S.E., 1978a; 1978b; 1978c; Tailleur, I.L., Pessel, G.H., and Engwicht, S.E., 1978; Tailleur, I.L., Pessel, G.H., Levorsen, J.A., and Engwicht, S.E., 1978;

U.S. Geological Survey, 1975; 1976; 1977; 1978; 1979;

Walker, H.J., 1974, 1976a, 1976b, Williams, J.R., Carter, L.D., and Yeend, W. E., 1978; Williams, J.R., Yeend, W.E., Carter L.D., and Hamilton, T.D., 1977; Witmer, R.J., 1980; 
AREA

Howard Pass

Alpha, T.R., and Gerin, Marybeth, 1980; Armstrong, A.K., 1975;

Barnes, D.F., 1977; Beikman, H.M., and Lathram, E.H., 1976;

Carter, R.D., Mul1, C.G., Bird, K.J., and Powers, R.B., 1977; Childers, J.M., and Kernodle, D.R., 1979; Churkin, Michael, Jr., Huie, Car1, Mayfield, C.F., and Nokleberg, W. J., 1978; Churkin, Michael, Jr., Mayfield, C.F., Theobald, P.K., Barton, Harlan, and others, 1978; Cobb, E.H., 1975; Curtis, S.M., Rossiter, Richard, Ellersieck, I.F., Mayfield, C.F., and Tailleur, I.L., $1979 \mathrm{a} ; 1.979 \mathrm{~b}$;

Decker, John, and Kar1, Susan, 1977; Degenhart, C.E., Griffis, R.J., McOuat, J.F., and Bigelow, C.G., 1978; Detterman, R. L., 1978; Donovan, T.J., and Tailleur, I.L., 1975; Dutro, J.T., Jr., 1979;

Galloway, J.P., and Carter, L.D., 1978; Gibson, H.A., and Tailleur, I.L., 1980; Grybeck, Donald, 1977; Grybeck, Donald, Beikman, H.M., Brosge, W.P., Tailleur, I.L., and Mul1, C.G., 1977; Grybeck, Donald, and DeYoung, J.H., Jr., 1978; Grybeck, Donald, and Nokleberg, W.J., 1979;

Hamilton, T.D., 1979; Hamilton, T.D., and Trexler, J.H., 1979; Hunter, R.E., and Fox, J.E., 1976;

Jansons, Uldis, and Baggs, D.W., 1980; Johnson, K.M., 1978;

Kachadoorian, Reuben, Crory, F.E., and Berg, R.L., 1979; Lange, I.M., and others, 1980;

Martin, G.C., and Callahan, J.E., 1978; Mayfield, C.F., Curtis, S.M., Ellersieck, I.F., and Tallleur, I.L., 1979; Mayfield, C.F., Tailleur, I.L., Mu11, C.G., and Silberman, M.L., 1978; Mu11, C.G., 1979;

Nelson, S.W., Nokleberg, W.J., Miller-Hoare, Martha, and Mullen, M.W., 1979; Nilsen, T.H., Moore, T.E., and Brosge, W.P., 1980; Nilsen, T.H., Moore, T.E., Dutro, J.T., Jr., Brosge, W.P., and Orchard, D.M., 1980; Nokleberg, W.J., and Winkler, G.R., 1978a; 1978b; 1978c;

Roeder, Dietrich, and Mu11, C.G., 1978;

Still, P.J., 1980a; 1980b;

Tailleur, I.L., Pessel, G.H., Brosge, W.P., and Mayfield, C.F., 1976; Tailleur, I.L., Ellersieck, I.F., and Mayfield, C.F., 1977; Theobald, P.K., and Barton, H.N., 1978; Theobald, P.K., Barton, H.N., Billings, T.,M., Frisken, J.G., and others, 1978;

U.S. Bureau of Mines, Alaska Field Operations Center, 1978a; 1978b; 1978c; 1979a; 1979b; 1980; U.S. Geological Survey, 1976;

Williams, J.R., Yeend, W.E., Carter, L.D., and Hamilton, T.D., 1977; 
Ikpikpuk River quadrangle

Alpha, T.R., and Gerin, Marybeth, 1980; Ahlbrandt, T.S., 1979a; 1979b; Ahlbrandt, T.S., Huffman, A.C., Jr., Fox, J.E., and Pasternack, Ira, 1979;

Barnes, D.F., 1977; Bartsch-Winkler, Susan, 1979; Beikman, H.M., and Lathram, E.H., 1976; Bird, K.J., and Andrews, Jack, 1979;

Carter, L.D., and Galloway, J.P., 1979; Carter, L.D., and Robinson, S.W., 1978; Carter, R.D., Mull, C.G., Bird, K. J., and Powers, R.B., 1977;

Childers, J.M., Kernodle, D. R., and Loeffler, R.M., 1979;

Decker, John and Kar1, Susan, 1977; Detterman, R.L., 1978;

Fox, J.E., 1979; Fox, J.E., Lambert, P.W., Pitman, J.K., and Wu, C.H., 1979;

Galloway, J.P., and Carter, L.D., 1978; Gibson, H.A., and Tailleur, I.L.., 1980; Grybeck, Donald, Beikman, H.M., Brosge, W.P., Tailleur, I.L., and Mull, C. G., 1977; Grybeck, Donald, and DeYoung, J.H., Jr., 1978;

Huffman, A.C., and Ah1brandt, T.S., 1979;

Johnson, K.M., 1978;

Kachadoorian, Reuben, Crory, F.E., and Berg, R.L., 1978; Kaiser Engineers, Inc.1977;

Magoon, L.B., and Claypool, G.E., 1978; 1979; Martin, G.C., and Callahan, J.E., 1978; Mayfield, C.F., Tailleur, I.L., Mull, C.G., and Sable, E.G., 1978; Mu11, C.G., 1979;

Nilsen, T.H., Moore, T.E., Dutro, J.T., Jr., Brosge, W.P, and Orchard, D.M., 1980 ;

Pewe, T.L., 1975;

Scott, R.A., and Smiley, C.J., 1979; S1iter, W.V., 1979; Sloan, Charles, Trabant; Dennis, and Glude, William, 1979; St111, P.J., 1980;

U.S. Bureau of Mines, Alaska Field Operations Center, 1980; U.S. Geologica1. Survey, 1979;

Williams, J.R., Carter, L.D., and Yeend, W.E., 1978; Williams, J.R., Yeend, W.D., Carter, L.D., and Hamilton, T. D., 1977; Witmer, R.J., 1980;

Yeend, W.E., 1978; 
AREA

Killik River quadrangle

Alpha, T.R., and Gerin, Marybeth, 1980; Ahlbrandt, T.S., 1979a; 1979b;

Ahlbrandt, T.S., Huffinan, A.C., Jr., Fox, J.E., and Pasternack, Ira, 1979;

Armstrong, A.K., 1975;

Barnes, D.F., 1977; Beikman, H.M., and Lathram, E.H., 1976; Bird, K.J., and Andrews, Jack, 1979; Bottge, R.G., 1975; Brosge, W.P., Reiser, H.N., Dutro, J.T., Jr., and Nilsen, T.H., 1979;

Carter, R.D., Mul1, C.G., Bird, K.J., and Powers, R.B., 1977; Childers, J.M., Kernodle, D.R., and Loeffler, R.M., 1979; Churkin, Michael, Jr., Mayfield, C.G., Theobald, P.K., Barton, Harlan, and others, 1978;

Decker, John, and Kar1, Susan, 1977; Degenhart, C.E., Griffis, R.J., McOuat, J.F., and Bigelow, C.G., 1978; Detterman, R.L., 1978; Donovan, T.J.and Tailleur, I.L., 1975; Dutro, J.T., Jr., 1979;

Gibson, H.A., and Tailleur, I.L., 1980; Grybeck, Donald, Beikman, H.M., Brosge, W.P., Tailleur, I.L. and Mull, C.G., 1977; Grybeck, Donald, and DeYoung, J.H., Jr., 1978;

Hamilton, T.D., and Trexler, J.H., Jr., 1979; Huffman, A.C., and Ahlbrandt, T.S., 1979; Hunter, R.E., and Fox, J.E., 1976;

Johnson, K.M., 1978;

Kaiser Engineers, Inc. 1977;

Martin, G.C., and Callahan, J.E., 1978; Mayfield, C.G., Tailleur, I.L., Mull, C.G., and Sable, E.G., 1978; Mayfield, C.G., Tailleur, I.L., Mull, C.G., and Silberman, M.L., 1978; Mu11, C.G., 1979; Mu11, C.G., Tailleur, I.L., Mayfield, C.F., and Pessel, G.H., 1976;

Nilsen, T.H., Moore, T.E., and Brosge, W.P., 1980; Nilsen, T.H., Moore, T.E., Dutro, J.T., Jr., Brosge, W.P., and Orchard, D.M., 1980;

Pewe, T.L., 1975; Platt, J.B., 1975;

Reiser, H.N., Brosge, W.P., DeYoung, J.H., Jr., Marsh, S.P., and others, 1979 ;

Scott, R.A., and Smiley, C.G., 1979; Sloan, Charles, Trabant, Dennis, and Glude, William, 1979; Still, P.J., 1980;

U.S. Bureau of Mines, Alaska Field Operations Center, 1978; 1979; 1980; U.S. Geological Survey, 1976;

Williams, J.R., Yeend, W.E., Carter, L.D., and Hamilton, T. D., 1977;

Yeend, W.E., 1978; 


\section{AREA}

Lookout Ridge quadrangle

Alpha, T.R., and Gerin, Marybeth, 1980; Ah1brandt, T.S., 1979a; 1979b;

Barnes, D.F., 1977; Beikman, H.M., and Lathram, E.H., 1976; Bird, K.J., and Andrews, Jack, 1979;

Carter, R.D., Mull, C.G., Bird, K.J., and Powers, R.B., 1977;

Decker, John, and Kar1, Susan, 1977; Detterman, R.J., 1978;

Galloway, J.P., and Carter, L.D., 1978; Gibson, H.A., and Tailleur, I.L., 1980; Glude, W.J., and Sloan, C.E., 1980; Grybeck, Donald, Beikman, H.M., Brosge, W.P., Tailleur, I.L., and Mul1, C.G., 1977; Grybeck, Donald, and DeYoung, J.H., Jr., 1978;

Huffman, A.C., and Ah1brandt, T.S., 1979;

Johnson, K.M., 1978;

Kaiser Engineers, Inc., 1977;

Mart1n, G.C., and Callahan, J.E., 1978; Mayfield, C.F., Tailleur, I.L., Mull, C.G., and Sable, E.G., 1978; Mull, C.G., 1979;

Pewe, T.L., 1975;

Sloan, Charles, Trabant, Dennis, and Glude, William, 1979; Still, P.J., 1980;

Williams, J.R., Carter, L.D., and Yeend, W.E., 1978; Williams, J.R., Yeend, W.D., Carter, L.D., and Hamilton, T.D., 1977;

Yeend, W.E., 1978;

Meade River quadrangle

Alpha, T.R., and Gerin, Marybeth, 1980; Ahlbrandt, T.S., 1979a; 1979b;

Barnes, D.G., 1977; Bartsch-Winkler, Susan, 1979; Beikman, H.M., and Lathram, E.H., 1976; Bird, K.J., and Andrews, Jack, 1979; Boucher, Gary, 1976;

Carter, L.D., and Galloway, J.P., 1979; Carter, L.D., Marinkovich, Louie, Jr., Brouwers, E.M., and Forester, R.M., 1979; Carter, R.D., Mull, C.G., Bird, K.J., and Powers, R. B., 1977; Childers, J.M., Kernodle, D.R., and Loeffler, R.M., 1979; Claypool, G.E., and Magoon, L.B., 1980;

Decker, John, and Karl, Susan, 1977; Detterman, R.L., 1978;

Galloway, J.P., and Carter, L.D., 1978; Greenberg, Jonathan, Hart, P.E., and Grantz, Arthur, 1979;

Hartz, R.W., 1978; Hopkins, D.M., and Hartz, R.W., 1978; Huffman, A.C., and Ahlbrandt, T.S., 1979; 
AREA

Meade River quadrangle ( $\operatorname{cont}^{\prime} \mathrm{d} \cdot$ )

Johnson, K.M., 1978;

Kaiser Engineers, Inc., 1.977;

Magoon, L.B., and Claypoo1, C.E., 1979; Mann, D.M., 1977; Martin, G.C., and Callahan, J.E., 1978;

Pewe, T.L., 1975;

Ruppe1, B.D., and McHendrie, A.G., 1975; 1976;

Schumacher, G.M., 1976; Sloan, Charles, Trabant, Dennis, and Glude, William, 1979; Still, P.J., 1980;

Toimil, L.J., 1978;

U.S. Geological Survey, 1975; 1976;

Williams, J.R., Yeend, W.E., Carter, L.D., and Hamilton, T. D., 1977;

Williams, J.R., Carter, L.D., and Yeend, W.E., 1978; Williams, J.R., and Yeend, W.E., 1979; Witmer, R.J., 1980;

Misheguk Mountain quadrangle

Ahlbrandt, T.S., 1979a; 1979b; Ahlbrandt, T.S., Huffman, A.C., Jr, Fox, J.E., and Pasternack, Ira, 1979; Alpha, T. R., and Gerin, Marybeth, 1980; Armstrong, A.K., 1974; 1975; Armstrong, A.K., and Mamet, B.L., 1977;

Barnes, D.F., 1977; Beikman, H.M., and Lathram, E.H., 1976; Bird, K.J., and Andrews, Jack, 1979;

Carter, R.D., Mul1, C.G., Bird, K.J., and Powers, R.B., 1977; Childers, J.M., and Kernodle, D.R., 1979; Childers, J.M., Kernodle, D.R., and Loeffler, R.M., 1979; Churkin, Michael, Jr., Huie, Carl, Mayfield, C.F., and Nokleberg, W.J., 1978; Churkin, Michael, Jr., Mayfield, C.F., Theobald, P.K., Barton, Harlan, and others, 1978;

Cobb, E.H., 1975; Curtis, S.M., Ellersieck, I.F., Mayfield, C.F., and Tailleur, I.L., 1980; Curtis, S.M., Kossiter, Richard, Ellersieck, I.F., Mayfield, C.F., and Tailleur, I.L., 1979a; 1979b;

Decker, John and Karl, Susan, 1977; Degenhart, C.E., Griffis, R.J., McOuat, J.F., and Bigelow, C.G., 1978; Detterman, R.L., 1978; Donovan, T.J., and Tailleur, I. L., 1975;

Ellersieck, I.F., Mayfield, C.F., Tailleur, I.L., and Curtis. S.M., 1979;

Gibson, H.A., and Tailleur, I.L., 1980; Grybeck, Donald, 1977; Grybeck, Donald, Beikman, H.M., Brosge, W.P., Tailleur, I.L., and Mu11, C.G., 1977; Grybeck, Donald, and DeYoung, J.H., Jr., 1978;

Huffman, A.C., and Ahlbrandt, T.S., 1979; 
AREA

Misheguk Mountain quadrangle (cont'd.)

Jansons, Uldis, and Baggs, D.W., 1980; Johnson, K.M., 1978; Jones, D.L., and Grantz, Arthur, 1964;

Kaiser Engineers, Inc., 1977;

Martin, G.C., and Callahan, J.E., 1978; Mayfield, C.F., Curtis, S.M., Ellersieck, I.F., and Tailleur, I.L., 1979a; 1979b; Mayfield, C.F., Tailleur, I.L., Mull, C.G., and Sable, E.G., 1978; Mu11, C.G., 1979; Mul1, C.G, Tailleur, I.L., Mayfield, C.F., and Pessel, G.H., 1976;

Nilsen, T.H., Moore, T.E., Dutro, J.T., Jr., Brosge, W.P., and Orchard, D.M., 1980 ;

Oliver, W.A., Jr., Merriam, C.W., and Churkin, Michael, Jr., 1975;

Roeder, Dietrich, and Mu11, C.G., 1978; Rowett, C.L., 1975;

Sliter, W.V., 1979; Sloan, Charles, Trabant, Dennis, and Glude, William, 1979; Sti11, P.J., 1980a; 1980b;

Theobald, P.K., and Barton, H.N., 1978; Theobald, P.K., Barton, H.N., Billings, T.M., Frisken, J.G., and others, 1978;

U.S. Bureau of Mines, Alaska Field Operations Center, 1978a; 1978b; 1979; 1980; U.S. Geological Survey, 1976;

Williams, J.R., Yeend, W.E., Carter, L.D., and Hamilton, T.D., 1977;

Yeend, W.E., 1978

Mount Michelson quadrangle

Albert, N.R.D., 1978; Alpha, T.R., and Gerin, Marybeth, 1980; Armstrong, A.K., 1975; Armstrong, A.K., and Mamet, B.L., 1975; 1977;

Barker, J.C., 1978; Barnes, D.F., 1977; Barnes, D.F., Kososki, B.M., Mayfield, C.F., Ruppel, B.D., and others, 1976; Beikman, H.M., and Lathram, E.H., 1976; Bird, K.J., 1976; 1978a; 1978b; Bird, K.J., Connor, C.L., Tailleur, I.L., Silberman, M.L., and Christie, J.L., 1978; Bird, K.J., and Jordan, C.G., 1976; 1977; Bottge, R.G., 1975; Brosge, W.P., and Reiser, H.N., 1976;

Carter, R.D., Mu11, C.G., Bird, K.J., and Powers, R.B., 1977; Childers, J.M., Sloan, C.E., Mecke1, J.P., and Nauman, J.W., 1977; Churkin, Michael, Jr., 1975; Cobb, E.H., 1975; Craig, P.C., and McCart, P.J., 1975;

Decker, John, and Karl, Susan, 1977; Detterman, R.I., 1976; 1978; Detterman, R.L., Reiser, H.N., Brosge, W.P., and Dutro, J.T., Jr., 1975; Donovan, T.J., and Tailleur, I.L., 1975; Dutro, J.T., Jr., 1979; 
AREA

Mount Michelson quadrangle (cont'd.)

Grantz, Arthur, and Mu11, C.G., 1978; Grybeck, Donald, 1977a; 1977b; Grybeck, Donald, Beikman, H.M., Brosge, W.P., Tailleur, I.L., and Mull, C.G., 1977; Grybeck, Donald, and DeYoung, J.H., Jr., 1978; Grybeck, Donald, and Nokleberg, W.J., 1979;

Hardin, Deborah, Barnes, P.W., and Reimnitz, Erk, 1977; Hartman, D.C., 1973;

Imlay, R.W., 1976;

Kososki, B.A., Reiser, H.N., Cavit, C.D., and Detterman, R.L., 1978;

Levorsen, J.A., Pessel, G.H., Carter, R.D., and Tailleur, I.L., 1978; Levorsen, J.A., Pessel, G.H., and Tallleur, I.L., 1978; Lyle, W.M., Palmer, I.F., Bolm, J.G., and Maxey, L.R., 1980;

Meckel, J.P., 1976; Mull, C.G., and Kososki, B.A., 1977;

Nilsen, T.H., Moore, T.E., and Brosge, W.P., 1980; Nilsen, T.H., Moore, T.E., Dutro, J.T., Jr., Brosge, W.P., and Orchard, D.M., 1980;

Oliver, W.A., Jr., Merriam, C.Q., and Churkin, Michael, Jr., 1975; Overstreet, W.C., Crenshaw, G.l., Hubert, A.E., Rosenblum, Sam, and Smith, R.J., 1975; Overstreet, W.C., Hamilton, J.C., Boerngen, J.G., Rosenblum, Sam, Marsh, W. R., and Sainsbury, C.L., 1975;

Pessel, G.H., Levorsen, J.A., and Tailleur, I.L., 1978a; 1978b; 1978c; 1978d; 1978e; Pesse1, G.H., and Tailleur, I.L., 1978; Pessel, G.H., Tallleur, I.L., and Bird, K.J., 1978a; 1978b; 1978c; 1978d; Pessel, G.H., Tailleur, I.L., and Levorsen, J.A., 1978; Peterson, L.A., 1979, Pewe, T.L., 1975; Post, Austin, and Meier, M.F., 1979;

Reiser, H.N., Brosge, W.P., Dutro, J.T., Jr., and Detterman, R.L., 1979; Repenning, C.A., 1978;

Sable, E.G., 1977; Shawe, D.R., ed., 1976; Sloan, C.E., 1976; Sti1l, P.J., 1980 ;

Tailleur, I.L., Bird, K.J., and Engwicht, S.E., 1978; Tailleur, I.L., and Engwicht, S.E., 1978a; 1978b; 1978c; Tailleur I.L., Pessel, G.H., and Engwicht, S.E., 1978; Tailleur, I.L., Pesse1, G.H., Levorsen, J.A., and Engwicht, S.E., 1978; Turner, D.L., Grybeck, Donald, and Wilson F.H., 1975;

U.S. Geological Survey, 1976; 1977;

Wilson, F.H., and Turner, D.L., 1975; Wood, G.V., and Armstrong, A.K., 1975b; 
AREA

Philip Sinith Mts. quadrangle

Ahlbrandt, T.S., 1979a; 1979b; Alpha, T.R., and Gerin, Marybeth, 1980; Armstrong, A.K., 1975; Armstrong, A.K., and Mamet, B.L., 1977;

Barker, J.C., 1978; Barnes, D.F., 1977; Beikman, H.M., and Lathram, E.H., 1976; Bottge, R.G., 1975; Brosge, W. P., Reiser, H.N., Dutro, J.T., Jr., and Detterman, R.L., 1977; 1979;

Cady, J.W., 1978; Calkin, P.E., and Ellis, J.M., 1978; Cathral1, J.B., Cooley, E.F., Detra, D.E., and Billings, T. M., 1977; Cathrall, J.B., Cooley, E.F., Detra, D.E., and O'Leary, R.M., 1977; Cathrall, J.B., Detra, D.E., and Cooley, E.F., 1978a; 1978b; 1978c; 1978d; 1978e; Cathra11, J.B., Detra, D.E., and O'Leary, R.M., 1978;

Childers, J.M., 1976; Childers, J.M., S1oan, C.E., Meckel, J.P., and Mauman, J.W., 1977; Craig, P.C., and McCart, P.J., 1975;

Decker, John, and Kar1, Susan, 1977; Degenhart, C.E., Griffis, R.J., McOuat, J.F., and Bigelow, C.G., 1978; Detra, D.E., 1977; Detterman, R.L., 1976; 1978; Donovan, T.J., and Tailleur, I.1., 1975;

Dutro, J.T., Jr., 1978; 1979; Dutro, J.T., Jr., Brosge, W.P., Lanphere, M.A., and Reiser, H.N., 1976; Dutro, J.T., Jr., Brosge, W.P., and Reiser, H.N., 1977; Dutro, J.T., Jr., Brosge, W.P., Reiser, H.N., and Detterman, R.L., 1979; Dutro, J.T., Jr., and Detra, D.E., 1978;

Ellis, J.M., and Calkin, Y.E., 1978;

Grantz, Arthur, and Mull, C.G., 1978; Grybeck, Donald, 1977; Grybeck, Donald, Beikman, H.M., Brosge, W.P., Tailleur, I. L., and Mu11, C.G., 1977; Grybeck, Donald, and DeYoung, J. H., Jr., 1978;

Halbouty, M.T., 1976; Hamilton, T.D., 1977; 1978a; 1978b; 1979a; 1979b; 1979c; Hamilton, T.D., and Thorson, R.M., 1976; Hardin, Deborah, Barnes, P.W., and Reimnitz, Erk, 1977; Huffman, A.C., and Ahlbrandt, T.S., 1979;

Lamke, R.D., and Jones, S.H., 1980; Le Compte, J.R., 1979; Mul1, C.G., 1979;

Nauman, J.W., and Kernodle, D.R., 1977; Nauman, J.W., and Sloan, C.E., and Kernodle, D.R., 1977; Nilsen, T.H., Moore, T.E., and Brosge, W.P., 1980; Nilsen, T.H., Moore, T.E., Dutro, J.T., Jr., Brosge, W.P., and Orchard, D.M., 1980;

Oliver, W.A., Jr., Merriam, C.W., and Churkin, Michael, Jr., 1975; Reiser, H.N., Brosge, W.P., DeYoung, J.H., Jr., Marsh, S. P., and others, 1979; Reiser, H.N., Brosge, W.P., Dutro, J.T., Jr., and Detterman, R.L., 1979;

Schoennagel, F.H., 1977; Scott, K.M., 1978; Slack, K.V., Nauman, J.W., and Tilley, L.J., 1977; Sloan, C.E., Zenone, Chester, and Mayo, L.R., 1975; 1976; Steele, W.C., Le Compte, J.R., and Albert, N.R.D., 1979; Still, P.J., 1980a; 1980b;

U.S. Geological Survey, 1974; 1976; 1977; 1978; 
Point Hope Quadrangle

Ahlbrandt, T.S., 1979a; 1979b; Ahlbrandt, T.S., Huffman, A.C., Jr., Fox, J.E., and Pasternack, Ira, 1979; Alaska Division of Geological and Geophysical Surveys, 1976; Armstrong, A.K., 1975; Armstrong, A.K., and Mamet, B.L., 1977;

Barnes, D.F., 1977; Bartsch-Winkler, Susan, 1979; Beikman, H.M., and Lathram, E.H., 1976; Bird, K.J., and Andrews, Jack, 1979;

Callahan, J.E., and Sloan, E.G., 1978; Childers, J.M, Kernodle, D.R., and Loeffler, R.M., 1979; Conwell, C.N., and Triplehorn, D.M., 1976;

Decker, John, and Kar1, Susan, 1977; Detterman, R.L., 1978; Donovan, T.J., and Tailleur, I.L., 1975; Dutro, J.T., Jr., 1979;

Eittreim, Stephen, Grantz, Arthur, and Whitney, O.T., 1978;

Grybeck, Donald, Beikman, H.M., Brosge, W.P., Tailleur, I. L., and Mull, C.G., 1977; Grybeck, Donald, and DeYoung, J. H.Jr., 1978;

Hopkins, D.M., 1977; Huffman, A.C., Jr., 1979; Huffman, A. C., and Ahlbrandt, T.S., 1979;

Kaiser Engineers, Inc., 1977;

Madison, R.J., 1976; Mann, D.M., 1977; Mul1, C.G., 1979;

Offshore, 1978a, 1978b, O11 and Gas Journal, 1977f, Owens, E.H., 1977;

Pewe, T.L., 1975; Platt, J.B., 1975;

Rowett, C.L., 1975; Ruppe1, B.D., and McHendrie, A.G., 1975; 1976;

Schumacher, G.M., 1976; Scott, R.A., and Smiley, C.J., 1979; Sti11, P.J., 1980;

Toimi.1, L.J., 1978;

U.S. Ceological Survey, 1975;

Point Lay quadrangle

Ahlbrandt, T.S., 1979a; 1979b; Ahlbrandt, T.S., Huftman, A.C., Jr., Fox, J.E., and Pasternack, Ira, 1979;

Barnes, D.F., 1977; Bartsch-Winkler, Susan, 1979; Beikman, H.M., and Lathram, E.H., 1976; Bird, K.J., and Andrews, Jack, 1979;

Callahan, J.E., and Sloan, C.E., 1978; Childers, J.M., Kernodle, D.R., and Loeffler, R.M., 1979;

Decker, John, and Kar1, Susan, 1977; Detterman, R.L., 1978;

Huffman, A.C., Jr., 1979; Huffman, A.C., and Ahlbrandt, T.S., 1979; 
Point Lay quadrangle (cont'd.)

Kaiser Engineers, Inc., 1977;

Magoon, L.B., and Claypoo1, G.E., 1979; Mann, D.M., 1977; Mul1, C.G., 1979;

Pewe, T.L., 1975; Platt, J.B., 1975;

Ruppe1, B.D., and McHendrie, A.G., 1975; 1976;

Schunacher, G.M., 1976; Short, A.D., and Wiseman, W.J., Jr., 1975; Sliter, W.V., 1979; Sloan, Charles, Trabant, Dennis, and Glude, William, 1979; Still, P.J., 1980;

Toimil, L.J., 1978;

Yeend, W.E., 1978;

\section{Sagavanirktok quadrangle}

Ahlbrandt, T.S., 1979a; 1979b; Albert, N.R.D., 1978; Alpha, T.K., and Gerin, Marybeth, 1980; Armstrong, A.K., and Mamet, B.L., 1977;

Barker, J.C., 1978; Barnes, D.F'., 1977; Beikman, H.M., and Lathram, E.H., 1976; Bird, K.J., 1978a; 1978b; 1976; Bird, K.J., and Jordan, C.F., 1976; 1977; Bottge, R.G., 1975;

Carter, R.D., Mu11, C.G., Bird, K.J., and Powers, R.B., 1977; Childers, J.M., Sloan, C.E., Meckel, J.P., and Nauman, J.W., 1977; Childers, J.M., Nauman, J.W., Kernodle, D.R., and Doyle, P.F., 1978; Craig, P.C., and McCart, P.J., 1975

Decker, John, and Kar1, Susan, 1977; Detterman, R.L., 1976a; 1976b; 1978; Detterman R.L., and Dutro, J.T., Jr., 1977; Detterman, R.l., Reiser, H.N., Brosge, W.P., and Dutro, J.T., Jr., 1975; Donovan, T.J., and Tallleur, I.L., 1975; Dutro, J.T., Jr., 1979;

Giovannetti, D.M., and Bird, K.J., 1978; 1979; Grantz, Arthur, and Mull, C.G., 1978; Brybeck, Donald, Beikman, H.M., Brosge, W.P., Tailleur, I.L., and Mull, C.G., 1977; Grybeck Donald, and DeYoung, J.H., Jr., 1978;

Halbouty, M.T., 1976; Hamilton, T.D., 1979; Hardin, Drborah, Barnes, P.W., and Reimnitz, Erk, 1977; Huffman, A.C., and Ahlbrandt, T.S., 1979; Imlay, R.W., 1976;

Levorsen, J.A., Pesse1, G.H., Carter, R.D., and Tailleur, I.L., 1978a; 1978b; Loeffler, R.M., and Childers, J.M., 1978; Mull, C.G., 1979;

Nauman, J.W., and Kernodle, D.R., 1975; 1977; Nauman, Sloan, C.E., and Kernodle, D.R., 1977; Nilsen, T.H., Moore, T.E., and Brosge, W.P., 1980; Nilsen, T.H., Moore, T.E., Dutro, J.T., Jr., Brosge, W.P., and Orchard, D.M., 1980; 
Sagavanirktok quadrangle (cont'd.)

Pesse1, G.H., Levorsen, J.A., and Tailleur, I.L., 1978a; 1978b; 1978c; 1978d; $1978 \mathrm{e}$; Pesse1, G.H., and Tailleur, I.L., 1978; Pesse1, G.H., Tailleur, I.L., and Bird, K.J., 1978a; 1978b; 1978c; 1978d; Pessel, G.H., Tailleur, I.L., and Levorsen, J.A., 1978a; Peterson, Laurence A. 1979; Pewe, T.L., 1975;

Reiser, H.N., Brosge, W.P., Dutro, J.T., Jr., and Detterman, R.L., 1979; Rowett, C.L., 1975;

Scott, K.M., 1978; Shallock, E.W., 1975; Sloan, C.E., Zenone, Chester, and Mayo, L.R., 1975; 1976; Sti11, P.J., 1980;

Tailleur, I.L., Bird, K.J., and Engwicht, S.E., 1978; Tailleur, I.L., and Engwicht, S.E., 1978a; 1978b; Tallleur, I.L., Pesse1, and Engwicht, S.E., 1978; Tailleur, I.L., Pessel, G.H., Levorsen, J.A., and Engwicht, S.E., 1978;

U.S. Geological Survey, 1974; 1977;

Table Mountain quadrangle

Alpha, T.R., and Gerin, Marybeth, 1980; Armstrong, A.K., 1975; Armstrong, A.K., and Mamet, B.L., 1975;

Barker, J.C., 1978; Barnes, D.F., 1977; Beikman, H.M., and Lathram, E.H., 1976; Bottge, R.G., 1975; Brosge, W.P., and Reiser, H.N., 1976; 1977a; 1977b; Brosge, W.P., Reiser, H.N., Dutro, J.T., Jr., and Detterman, R.L., 1976;

Cobb, E.H., 1975; Craig, P.C., and McCart, P.J., 1975;

Decker, John, and Kar1, Susan, 1977; Detterman, R.L., 1976; Detterman, R.L., Reiser, H.N., Brosge, W.P., and Dutro, J.T., Jr., 1975; 1979; Donovan, T.J., and Tailleur, I.L., 1975;

Grantz, Arthur, and Mu11, C.G., 1978; Grybeck, Donald, 1977a; 1977b; Grybeck, Donald, Beikman, H.M., Brosge, W.P., Tailleur, I.L., and Mul1, C.G., 1977; Grybeck, Donald, and DeYoung, J.H., Jr., 1978;

Hardin, Deborah, Barnes, Peter, and Reimnitz, Erk, 1977;

Ni.lsen, T.H., Moore, T.E., and Brosge, W.P., 1980; Nilsen, T.H., Moore, T.E., Dutro, J.T., Jr., Brosge, W.P., and Orchard, D.M., 1980;

U.S. Geological Survey, 1977; 
AREA

Teshekpuk quadrangle

Ah1brandt, T.S., 1979a; 1979b; Alpha, T.R., and Gerin, Marybeth, 1980;

Barnes, D.F., 1977; Barnes, P.W., and Garlow, Richard, 1975; Barnes, P.W., and McDowe11, David, 1978; Barnes, P.W., and Reimnitz, Erk, 1976; Barnes, P.W., Reimnitz, Erk, Drake, D.E., and Toimil, L.J., 1977; Barnes, P.W., and Toimil, L.J., 1979; Bartsch-Winkler, Susan, 1979; Beikman, H.M., and Lathram, E.H., 1976; Bird, K.J., 1978; Bird, K.J., and Andrews, Jack, 1979;

Carter, L.D., and Galloway, J.P., 1979a; 1979b; Carter, L.D., Marincovich, Louie, Jr., Brouwers, E.M., and Forester, R.M., 1979; Carter, L.D., and Robinson S.W., 1978; Carter, R.D., Mull, C.G., Bird, K.J., and Powers, R.B., 1977;

Childers, J.M., Kernodle, D.R., and Loeffler, R.M., 1979; Churkin, Michael, Jr., 1975; Claypoo1, G.E., and Magoon, L.B., 1980; Curtis, S.M., and Rossiter, Richard, 1979; Curtis, S.M., Rossiter, Richard, Ellersieck, I.F., Mayfield, C.F., and Tailleur, I.L., 1979;

Decker, John, and Kar1, Susan, 1977; Detterman, R.L., 1978;

Galloway, J.P., and Carter, L.D., 1978; Glude, W.J., and Sloan, C.E., 1980; Grantz, Arthur, Barnes, P.W., Dinter, D.A., Lynch, M.B., Reimnitz, Erk, and Scott, E.W., 1980; Grantz, Arthur, Barnes, P.W., Eittreim, S.L., Reimnitz, Erk, Scott, E.W., and others, 1976; Greenberg, Jonathan, Hart, P.E., and Grantz, Arthur, 1979;

Hartz, R.W., 1978; Hopkins, D.M., and Hartz, R.W., 1978; Huffman, A.C., and Ahlbrandt, T.S., 1979;

Imlay, R.W., 1976; Johnson, K.M., 1978; Jones, S.H., 1978; Kaiser Engineers, Inc., 1977; LaBelle, J.C., 1976,

Magoon, L.B., and Claypoo1, G.E., 1978; 1979a; 1979b; 1980; Martin, G.C., and Callahan, J.E., 1978; Maurer, D.K., Barnes, P.W., and Reimnitz, Erk, 1978; May, F.E., and Stein, J.A., 1979;

Nilsen, T.H., Moore, T.E., Dutro, J.T., Jr., Brosge, W.P., and Orchard, D.M., 1980; Pewe, T.L., 1975;

Reimnitz, Erk, Barnes, P.W., and Kempema, Edward, 1979; Rodeick, C.A., 1979; Schumacher, G.M., 1976; Shaw, D.G., Smith, E.R., and McIntosh, D.J., 1977; Sloan, Charles, Trabant, Dennis, and Glude, William, 1979; Still, P.J., 1980;

Turner, D.L., Grybeck, Donald, and Wilson, F.H., 1975; U.S.Geological Survey, $1975 ; 1977 ; 1978 ; 1979$;

Williams, J.R., Carter, L.D., and Yeend, W.E., 1978; Williams, J.R., Yeend, W.E., Carter, L.D., and Hamilton, T.D., 1977; Wilson, F.H., and Turner D.L., 1975; Witmer, R.J., 1980; 
Umiat quadrangle

Ahlbrandt, T.S., 1979a; 1979b; Albert, N.R.D., 1978; Alpha, T.R., and Gerin, Marybeth, 1980;

Barnes, D.F., 1977; Bartsch-Winkler, Susan, 1979; Beikman, H.M., and Lathram, E.H., 1976; Bird, K.J., 1976; 1978a; 1978b; Bird, K.J., and Andrews, Jack, 1979; Bird, K.J., and Jordan, C.F., 1976; Bottge, R.G., 1975;

Carter, L.D., and Galloway, J.P., 1979a; 1979b; Carter, L.D., Repenning, C.A., Marincovich, L.M., Hazel, J.E., Hopkins, D.M., McDougall, Kristin, and Naeser, C.W., 1977; Carter, L.D., and Robinson, S.W., 1978; Carter R.D., Mull, C.G., Bird, K.J., and Powers, R.B., 1977; Childers, J.M., Kernodle, D.R., and Loeffler, R.M., 1979; Childers, J.M., Sloan, C.E., Meckel, J.P., and Mauman, J.W., 1977; Cobb, E.H., 1975;

Decker, John, and Kar1, Susan, 1977; Detterman, R.L., 1978;

Fox, J.E., 1979; Fox, J.E., Lambert, P.W., Pitman, J.K., and Wu, C.H., 1979;

Galloway, J.P., and Carter, L.D., 1978; Glude, W.J., and Sloan, C.E., 1980; Grybeck, Donald, Beikman, H.H., Brosge, W.P., Tailleur, I.L., and Mul1, C.G., 1977; Grybeck, Donald, and DeYoung, J.H., Jr., 1978;

Halbouty, M.T., 1976; Huffman, A.C., and Ahlbrandt, T.S., 1979; Johnson, K.M. , 1978;

Kachadoorian, Reuben, Crory, F.E., and Berg, D.L., 1978; 1979; Kaiser Engineers, Inc., 1977; Kososki, B.A., and Anderson, R.C., 1977;

Lathram, E.H, 1976, Lathram, E.H., and Albert, N.R., 1976; Levorsen, J.A., Pessel, G.H., Carter, R.D., and Tailleur, I.L., 1978; Levorsen, J.A., Pessel, G.H., and Tailleur, I.L., 1978;

Magoon, L.B., and Claypool, G.E., 1979a; 1979b; Martin, G.C., and Callahan, J.E., 1978; May, F.E., 1979; Mayfield, C.F., Tailleur, I.L., Mull, C.G., and Sable, E. G., 1978; Morgan, A.V., Morgan, Anne, and Carter, L.D., 1979; Mowatt, T.C., Naidu, A.S., and Veach, Namok, 1974; Mull, C.G., 1979;

Pesse1, G.H., Levorsen, J.A., and Ta1lleur, I.L., 1978a; 1978b; 1978c; 1978d; 1978e; Pesel, G.H., and Tailleur, I.L., 1978; Pessel, G.H., Tailleur, I.L., and Bird, K.J., 1978a; 1978b; 1978c; 1978d; Pessel, G.H., Tailleur, I.I.., and Levorsen, J.A., 1978; Peterson, Laurence A., 1979, Pewe, T.L., 1975;

Reiser, H.N., Brosge, W.P., Dutro, J.T.,Jr., and Detterman, R.L., 1979; Scott, R.A., and Sniley, C.J., 1979; Sliter, W.V., 1979; Sloan, Charles, Trabant, Dennis, and Glude, Willliam, 1979; Still, P.J., 1980;

Tailleur, I.L., and Engwicht, S.E., 1978a; 1978b; 1978c; Tailleur, I.L., Pessel, G.H., and Engwicht, S.E., 1978; Tailleur, I.L., Pessel, G.H., Levorsen, J.A., and Engwicht, S.E., 1978; 
Umiat quadrangle (cont'd.)

U.S. Bureau of Mines, Alaska Field Operations Center, 1980; U.S. Geological Survey, $1974 ; 1977$;

Williams, J.R., Carter, L.D., and Yeend, W.E., 1978; Williams, J.R., Yeend, W.E., Carter, L.D., and Hamilton, T. D., 1977;

Yeend, W.E., 1978;

Utukok River quadrangle

Ah1brandt, T.S., 1979a; 1979b; Ah1brandt, T.S., Huffman, A.C., Jr., Fox, J.E., and Pasternack, Ira, 1979; Alpha, T.R., and Gerin, Marybeth, 1980;

Barnes, D.F., 1977; Bartsch-Winkler, Susan, 1979; Beikman, H.M., and Lathram, E.H., 1976; Bird, K.J., and Andrews, Jack, 1979;

Callahan, J.E., 1976; Callahan, J.E., and Sloan, C.E., 1978; Carter, R.D., Mull, C.G., Bird, K.J., and Powers, R.B., 1977; Childers, J.M., Kernodle, D.R., and Loeffler, R.M., 1979;

Decker, John, and Kar1, Susan, 1977; Detterman, K.L., 1978;

Gibson, H.A., and Tailleur, I.L., 1980;

Hluffman, A.C., and Ahlbrandt, T.S., 1980;

Johnson, K.M., 1978;

Kaiser Engineers, Inc., 1977;

Magoon, L.B., and Claypool, G.E., 1979; Martin, G.C., and Callahan, J.E., 1978; Mayfield, C.F., Tailleur, I.L., Mull, C.G., and Sable, E.G., 1978; Mull, C.G., 1979;

Pewe, T.L., 1975;

Roehler, H.W., and Stickler, G.D., 1979;

Scott, R.A., and Smiley, C.J., 1979; Sliter, W.v., 1979; Sloan, Charles, Trabant Dennis, and Glude, William, 1979; Stil1, P.J., 1980;

Williams, J.R., Carter, L.D., and Yeend, W.E., 1978; Williams, J.R., Yeend, W.E., Carter, L.D., and Hamilton, T.D., 1977;

U.S. Bureau of Mines, Alaska Field Operations Center, 1980;

Yeend, W.E., 1978; 
Wainwright quadrangle

Ahlbrandt, T.S., 1979a; 1979b; Alpha, T.R., and Gerin, Marybeth, 1980;

Barnes, D.F., 1977; Beikman, H.M., and Lathram, E.H., 1976; Bird, K.J., and Andrews, Jack, 1979; Boucher, Gary, 1976;

Callahan, J.E., and Sloan, C.E., 1978; Carter, R.D., Mull, C.G., Bird, K.J., and Powers, R.B., 1977; Childers, J.M., Kernodle, D.R., and Loeffler, R.M., 1979;

Decker, John, and Karl, Susan, 1977; Detterman, R.L., 1978; Donovan, T.J., and Tailleur, I.L., 1975;

Hartz, R.W., 1978; Hopkins, D.M., Hartz, R.W., and Robinson, S.W., 1979; Hopkins, D.M., and Robinson, S.W., 1979; Huffman, A.C., and Ahlbrandt, T.S., 1979;

Kachadoorian, Reuben, Crory, F.E., and Berg, D.L., 1978; 1979; Kaiser Engineers, Inc., 1977;

Martin, G.C., and Callahan, J.E., 1978; Mann, D.M., 1977;

Pewe, T.L., 1975;

Ruppe1, B.D., and McHendrie, A.G., 1975; 1976;

Schumacher, G.M., 1976; Scott, R.A., and Smiley, C.J., 1979; Short, A.D., and Wiseinan, W.J., Jr., 1975; Sloan, Charles, Trabant, Dennis, and Glude, William, 1979; Still, P.J., 1.980;

Toimil, L.J., 1978;

U.S. Geological Survey, 1979;

Williams, J.R., Carter, L.D., and Yeend, W.E., 1978; Williams, J.R., Yeend, W.E., Carter, L.D., and Hamilton, T.D., 1977; Witmer, R.J., 1980; 


\section{BIBLIOGRAPHY}

General: AEIDC, 1979a; 1979b; AINA, 1974; Blean, K.M., 1976; Carter, R.D., and Denman, J.M., and Pierpoint, J.G., 1975; Cobb, E.H., 1975a; 1975b; 1976; 1977; 1978; 1979a; 1979b; 1979c; 1980; Coury, A.B., Hendricks, T.A., and Tyler, T.F., 1978;

Coal: Walker, F.K., 1975;

Ice: Ficke, E.R., and Ficke, J.F., 1977;

Water Resources: Feulner, A.J., and Reed, K.M., 1977;

EARTHQUAKES: Simon, R.B., Stover, C.W., Peterson, W.J., and Minsch, J.H., 1978;

\section{ECONOMIC GEOLOGY}

Coal: Bottge, R.G., 1975a; Callahan, J.E., 1975; 1976; Callahan, J.E., and Sloan, C.E., 1978; Coleman, J.M., 1976; Conwel1, C.N., and Triplehorn, D.M., 1976; Kaiser Engineers, Inc., 1977; Lynch, D.F., Johanson, N.L., and Lambert, C., Jr., and others, 1976; Martin, G.C., and Callahan, J.E., 1978; McGee, D.L., and O'Connor, K.M., 1975; Tailleur, I.L., and Brosge, W.P., 1975; 1976; Triplehorn, D.M., 1976; Wanek, A.A., 1974;

Construction Materials: LaBelle, J.C., 1976; Molnia, B.F., 1979;

Energy: Bottge, R.G., 1975; Siefert, R., 1977; U.S. Bureau of Land Management, 1974; Witten, Wesley, 1978;

Fluoride: Shawe, D.R., ed., 1976; Metallic Minerals: Clark, A.L., Berg, H.C., Cobb, E.H., Eberlein, G.D., MacKevett E.M., and Miller, T.P., 1974 ;

Mineral Appraisal: U.S. Bureau of Mines, 1978a; 1978b; 1978c; 1979a; 1979b; 1980 ;

Mineral Deposits: Barker, J.C., 1978; Brosge, W.P., and Reiser, H.N., 1977b; Carnes, David, 1980; Dutro, J.T., 1978; Engineering and Mining Journal, 1977; Grybeck, Donald, 1977a; Grybeck, Donald, and Nokleberg, W.J., 1979; Holden, G.D., Katz, D.L., and Hand, J.H., 1976;

Mayfield, C.F., Curtis, S.M., Ellersieck, I.F., and Tailleur, I.L., 1979a; Nockleberg, W.J., and Winkler, G.R., 1978a; 1978b; 1978c; Plahuta, J.T., Lange, I.M., and Jansons, Uldis, 1978; Tailleur, I.L., Mayfield, C.F., and Ellersieck, Inyo, 1980; U.S. Bureau of Mines, 1975 ;

Mineral Investigations: Jansons, Uldis, and Baggs, D.W., 1980;

Mineral Resources: Churkin, Michael, Jr., Hule, Car1, Mayfield,C.F., and Nokleberg, W.J., 1978; Churkin, Michae1, Jr., Mayfield, C.F., Theobald, P.K., Barton, Harlan, Nokleberg, W.J., Winkler, G.R., and Huie, Carl, 1978; Degenhart, C.E., Griffis, R.J., McOuat, J.F., and Bigelow, C.G., 1978; 
Mineral Resources (cont'd.): Mulligan, J.C.H., and others, 1978; National Petroleum Reserve in Alaska Task Force, 1978b; 1978e; 1979a; 1979b; National Petroleum Reserve in Alaska Work Group 5, 1979; Tailleur, I.L., Ellersieck, I.F., and Mayfield, C.F., 1977; U.S. Bureau of Mines, 1977;

Minerals: U.S. Bureau of Mines, 1977; 1978d; 1978e; U.S. Senate, 1974a;

Petroleum and Natural Gas Analyses: Moore, B.J., 1976;

Basin Maturity: Magoon, L.B., and Claypool, G.E., 1980a; 1980b; 1980c; 1980d; 1980e; 1980f;

Developments

Beaufort shelf: Grantz, Arthur, Barnes, P.W., Dinter, D.A., Lynch, M.B., Reimnitz, Erk, and Scott, E.W., 1980; Grantz, Arthur, Barnes, P.W., Eittreim, S.L., Reimnitz, Erk, Scott, E.W., Smith, R.A., Stewart, George, and Toimil, L.J., 1976; Grantz, Arthur, and others, 1980; Petroleum Information, 1978;

general: World Petroleum Congress, 1975a;

Kuparuk: 011 and Gas Journal, 1979c;

problems: Grantz, Arthur, and Dinter, D.A., 1980;

Prudhoe Bay: Offshore, 1979b; World 01.1, 1975a;

regional: McIvor, D.K., and Gryc, George, 1975;

scenarios: Dames and Moore, 1978b;

Drilling: McCaslin, J.C., 1977; $0 i 1$ and Gas Journal, 1980q; Wilson, H.M., 1980; Pratt, R.M., Andrews, J.K., and Simonson, R.R., 1977;

Exploration: Gryc, George, Mul1, C.G., and Tailleur, I.L., 1978; Hartz, R.W., Holden, K., Hopkins, D.M., and Shearer, C., 1979; Offshore, 1975a 1975c; 1975d; 1977a; 1977b; 1977c; 1978b; 0i1 and Gas Journal, 1975a; 1975c; 1975d; 1975e; 0il and Gas Journal, 1975f ; $1975 \mathrm{~g} ; 1975 \mathrm{~h} ; 1976 \mathrm{~b} ; 1977 \mathrm{~b} ; 1977 \mathrm{f} ; 1977 \mathrm{~g} ; 1977 \mathrm{~h} ; 1977 \mathrm{i} ; 1977 \mathrm{j}$; $1979 \mathrm{~b} ; 1979 \mathrm{~d} ; 1979 \mathrm{e} ; 1 \mathrm{1.979f} ; 1979 \mathrm{~g} ; 1979 \mathrm{~h} ; 1979 \mathrm{i} ; 1980 \mathrm{~b} ; 1980 \mathrm{c}$; $1980 \mathrm{j} ; 1980 \mathrm{p}$;

Patterson, S.0., and Harris, K.R., 1978; Petroleum Engineeer, 1974; 1980; Porterfield, Bob, 1974; Roy, K.J., Proctor, R.N., and McCrossan, R.G., 1975; Siefert, W.K., Moldowan, J.M., and Jones, R.W., 1.979; Sheils, M., and others, 1979; Tailleur, I.L., and Engwicht, S.E., 1978c; Time Magazine, 1979; World 0il, 1975b; Yorath, C.J., Parker, E.R., and Class, D.J., 1975;

General: Carter, R.D., and Lantz, R.J., 1978; 1979; Enzer, H., 1976; Grantz, Arthur, Boucher, Gary and Whitney, 0.T., 1976; Kent, Alan, 1977; Oil and Gas Journal, 1976a; 1977a; 1977d; 1979a; 1980d; 1980f; $1980 \mathrm{~g}$;

Shaw, D.G., Smith, E.R., and McIntosh, D.J., 1977; Shaw, D.G., 1976; Smith, E.R., 1976; U.S. Department of Energy, 1978; Weller, G., and Norton, D.W., 1977; Young, Allen, Monaghan, P.H., and Schweissberger, R.T., 1977; 


\section{SUBJECT}

Petroleum and Natural gas (cont'd.):

Leasing: Alaska Department of Natural Resources, 1979; 011 and Gas Journal, 1980e; 1980h; 1980i; 1980m; 1980o; Wilson, Howard, 1979; Wilson, H.M., 1979 ;

Oil types: Magoon, L.B., and Claypool, G.E., 1979b;

Oil and Gas Fields: Bowerman, J.N., and Coffman, R.C., 1975; Jamison, H.C, Brockett, L.D., and MicIntosh, R.A., 1979; Larminie, F.G., 1977; Wilson, H.M. , 1977;

Potential: Bird, K.J., 1976b; Bird, K.J., and Jordan, C.F., 1976a; 1976b; 1977a; 1977b; Carter, R.D., Mul.1, C.G., and Bird, K.J., 1977; Carter, R.D., Mul1, C.G., Bird, K.J., and Powers, R.B., 1977; Grantz, Arthur, and Eittreim, S.L., 1977; Grantz, Arthur, and Mul1, C.G., 1978; Mull, G.E., and Kososki, B.A., undated; 011 and Gas Journal, 1977c; Snowdon, L.R., 1980;

Production: Harrison, G.R., 1980; 011 and Gas Journal, 1980a;

Reserves: Lowel1, J.D., 1976; Oil and Gas Journal, 19751; Van Dyke, W.P., 1980

Reservoirs: AAPG, 1979; Alaska 0i.1 and Gas Conservation Commission, 1978; 1980; American Petroleum Institute, American Gas Association and Canadian Petroleum Association, 1974; Eckelmann, W.R., DeWitt, R.J., and Fisher, W.L., 1975; Eckelmann, W.R., Fisher, W.L., and DeWitt, R.J., 1976; Fox, J.E., 1979; Fox, J.E, Lambert, P.W., Pitman, J.K., and Wu, C.H., 1979; Fraser, G.S., 1977;

Jones, H.P., and Speers, R.G., 1976; Lyle, W.M., Palmer, I.F., Jr., Bolm, J.G., and Maxey, L.R., 1980; Magoon, L.B., and Claypoo1, G.E., 1979; McIntosh, Ron, 1977; 011 and Gas Journal, 1975b; 1978; 1980k; Palmer, I.F., Jr., Boln, J.G., Maxey, L.R., and Lyle, W.M., 1979;

U.S. Senate, 1974b; Wadham, D.H., Lamprecht, C.E., and Mrosousky, Ivan, 1979; World Petroleum Congress, 1975a; Van Poolen, H.K., and Assoc., 1974 ; 1976;

Resources and Possibilities: Collins, R.J., 1974; Mast, R.F., McMullin, R.H., Bird, K.J., and Brosge, W.P., 1980; Miller, B.M., and others, 1975; Mu11, C.G., and Kososki, B.A., 1977; Offshore, 1978a; 0il and Gas Journal, 1977e; She11, 1978; White, L.P., 1979;

Status Reports: Singletary, M.K., 1978;

We11 Records: Brosge, W.P., and Armstrong, A.K., 1977; Claypool, G.E., and Magoon, L.B., 1980a; 1980b; 1980c; U.S. Geological Survey, 1978c; $1979 \mathrm{e} ; 1980 \mathrm{~g}$; 


\section{SUBJECT}

ENGINEFRING GEOLOGY

Airfields: Kachadoorian, Reuben, Crory, F.E., and Berg, R.L., 1979;

Arctic: Wellman, J.H., Clarke, E.S., and Condo, A.C., 1976;

General: Muggeridge, D.B., ed., and Peters, G.R., Chm., 1977; Northern Engineering Services, Co., Ltd., 1975; Norwegian Institute of Technology, 1979; PBUWTF, 1979; Shearer, G.B., and Miller, D.L., 1979;

Gravel Islands: Hopkins, D.H., ed., 1978; Jahns, Hans 0., 1979;

Haul Road: Everett, K.R., 1980;

Harbors and Rivers: U.S. Army Corps of Engineers, 1975;

Permafrost Problems: Committee on Permafrost, 1975;

Port and Ocean: Burre1l, 1. C., chm., 1975;

Soil Studies: Harding-Lawson Associates, 1975; Harding-Lawson Associates and $\mathrm{Ch}_{2} \mathrm{M}$ Hil1, 1979; Moening-Grey Associates, 1976; undated;

Trans-Alaska Pipeline: Baker, J. Behlke, C.E., Brooks, C.R., eds., and others, 1976; Donovan, N.C., and Singh, S., 1976; Kreig, R.A., and Reger, R.D., 1976; Mollard, J.D., 1978; U.S. National Research Counci1, 1975;

\section{ENVIROIJMENT}

Development: AEIDC, 1980; West, G.C., 1976;

Genera1: Dames and Moore, 1978; Nauman, J.W., and Kernodle, D.R., 1977; 011 and Gas Journal, 1980i;

Impact Statements: Federal Energy Regulatory Comission, 1980; U.S. Army Corps of Engineers, 1980; U.S. Bureau of Land Management, 1978; 1979; U.S. Departinent of the Interior, 1978; U.S. Department of the Navy, $1.975 ; 1977$;

Marine: Barnes, P.W., Reimnitz, Erk, and Drake, D.E., 1976b; Grider, G.W., Robilard G.A., and Firth, R.W., Jr., 1977; 1978; Niedoroda, A., Chin, H., and Mangare11a P., 1979; NOAA/BLM, 1978; Reimnitz, Erk, and Toimil, L.J., 1977 ;

Oil Spills: Arctec, Inc., 1978; Barnes, P.W., Reimnitz, Erk, Toimil, L.J., and Hill, H.R., 1979; Johnson, L.A., Sparrow, E.B., Jenkins, T.F., and others, 1980; Nauman, J.W., and Kernodle, D.R., 1975; Nauman, J.W., Sloan, C.E., and Kernodle, D.R., 1977; Numendal, Dag, Fisher, J.A., and Knoth, J.S., 1978;

Kesource Development: Belon, A.E., Miller, J.M., and Stringer, W.J., 1975; Schallock, E.W., 1975; U.S. Geological Survey, 1979a; 
Trans-Alaska Pipeline: Meckel, J.P., 1976; Schmidt, R.A.M., and Champion, C.A., 1976; Burger, C., and Swenson, L., 1977;

GENERAL: Jamison, H.C., Brockett, L.D., and McIntosh, R.A., 1979; U.S. News, 1979; World 0i1, 1975;

Annual Reports: Alaska Division of Geological and Geophysical Surveys, 1976; Anchorage Oil Scouts Association, 1976;

Atlas: Walker, D.A., and others, 1980;

Developments: Herrera, R.C., 1977; 1978; Hiles, K.M., Gryc, George, Dobey, P.L., and Erwin, M.I., 1975; Jones, B.C., 1979; 1980a; Williams, P.J., 1979; Work, P.L., 1980;

Gas Pipeline: Alaska Information Service, 1980;

Gazeteer: Gerin, Marybeth, and Alpha, T.R., 1979;

Land Resources: National Petroleum Reserve in Alaska Task Force, 1978c; 1978d;

Management: Alaska Consultants, Inc., 1978; Hickock, D.M., 1976; U.S. Bureau of Land Management, 1978; U.S. Department of the Interior, 1979; 1980 ;

Programs: Blean, K.M., 1977; Johnson, K.M., ed, 1978;

Research: AEIDC, 1976; 1977; 1978; 1979; 1980; 0il and Gas Journal, 1980n; U.S. Geological Survey, 1974a; 1975a; 1976a; 1977; 1978a; 1979d; Yount, M.E., ed., 1975;

Statistical Reports: State of Alaska, 1978;

Summary Reports: Namtvedt, Thomas, Parrish, Scott, Freise, Nancy, 1974; Selkregg, L.L., 1975; Tetra Tech, 1978; 1980; Weller, G., Norton, D.W., and Johnson, T., eds., 1977; Energy Interface Associates, 1979;

GEOCHEMISTRY: Brosge, W.P., and Reiser, H.N., 1977a; Detra, D.E., 1977; Ellerse1ck, Inyo, Curtis, S.M., Gruzensky, A.L., Mayfield, C.F., and Tailleur, I.L., 1980; Lange, I.M., and others, 1980a; 1980b; Magoon, L.B., and Claypool, G.E., 1978;

Overstreet, W.C., Crenshaw, G.L., Jubert, A.E., Rosenblum, Sam and Smith, R.J., 1975; Overstreet, W.C., Hamilton, J.C., Boerngen, J.G., Rosenblum, Sam, Marsh, W.R., and Sainsbury, C.L., 1975; Powe11, T.G., Cook, P.J., and McCurdy, D.M., 1975; Theobald, P.K., and Barton, H.N., 1978; Theobald P.K., Barton, H.N., Billings, T.M., Frisken, J.G., Turner, R.L., and Van Trump, George, Jr., 1978; Weiss, H.V., and others, 1974;

\section{GEOLOGY}

Alaska Continental Terrace: Grantz, Arthur, Hanna, W.F., and Ruppel, B.D., 1974; 
GEOLOGY (cont'd.)

Barrow Arch: Bird, K.J., Connor, C.L., Tailleur, I.L., Silberman, M.L., and Christie, J.L., 1978; Churkin, Michael, Jr., 1975;

Beaufort-Mackenzie Basin: Jones, P.B., Brache, J., and Lentin, J.K., 1980; Young, F.G., Myhr, D.W., and Yorath, C.J., 1976;

Brooks Range, eastern: Reiser, H.N., Brosge, W.P., Dutro, J.T., Jr., and Detterman, R.L., 1979 ;

Cenozoic: Carter, L.D., Repenning, C.A., Marincovich, L.N., Hazel, J.E., Hopkins, D.M., McDowel1, Kristin, and Naeser, C.W., 1977;

Chukchi Sea: Grantz, Arthur, Wolf, S.C., Breslau, Lloyd, Johnson, T.C., and Hanna, W.F., 1975;

Continental Margin: Grantz, Arthur, Eittreim, S.L., and Dinter, D.A., 1979;

Doonerak Structural High: Dutro, J.T., Jr., Brosge, W.P., Lanphere, M.A., and Reiser, H.N., 1976;

General: Buchan, S.H., 1977; Drumunond, K.J., 1974; Dutro, J.T., Jr, 1979; Grantz, Arthur, May, S.D., Rupert, J.P., and Whitney, 0.T., 1977a; 1977b; Gramberg, I.S., and Kulakov, Yu N., 1975; Olsen, E.W., Carlson, P.W., and Molnia, B.F., 1980; Tailleur, I.L., and Pessel, G.H., 1976; U.S. Geological Survey, 1978b; 1980a;

Haul Road: Hamilton, T.D., 1979b;

Historical: Calkin, P.E., and Ellis, J.M., 1978; Clark, D.L., 1975; Sweeney, J.F., 1980;

NPRA: National Petroleum Reserve in Alaska Task Force, 1978a; U.S. Geological Survey, 1977a;

Nanushuk Group: Ahlbrandt, T.S., 1979a; 1979b; Bird, K.J., and Andrews, Jack, 1979;

Ophiolites: Nelson, S.W., Nokleberg, W.J., Miller-Hoare, Martha, and Mullen, M.W., 1979;

Quaternary: Pewe, T.L., 1975;

Romanzof Mts.: Sable, E.G., 1977;

U1tramafic complex, Avan Hills: Zimmerman, Jay, and Soustek, P.G., 1979;

Yukon, northern, and NW McKenzie: Norris, D.K., 1980;

GEOMORPHOLOGY (see also; areas, marine geology)

Barrier Islands: Reimnitz, Erk, Barnes, P.W., and Melchoir, J., 1977; Reimnitz, Erk, and Maurer, D.K., 1979a; Reimnitz, Erk, Ross, Robin, and Barnes, P.W., 1980; Short, A.D., 1976; 19791; 


\section{SUBJEC'T}

GEOMORPHOLOGY, (Cont'd.)

Bars: Short, A.D., 1975;

Beaches: Burre11, D.C., Dygas, J.A., and Tucker, R.W., 1974; Harper, J.R., Owens, E.H., and Wiseman, W.J., Jr., 1978; Short, A.D.,

1974; Short, A.D., Coleman, J.M., and Wright, L.D., 1974;

Benthos Effects: Hoskin, C.M., 1976;

Coastal: Barnes, P.W., and Ross, Robin, 1980; Harper, J.R., 1978a; 1978b;

Hopkins, D.M., 1977; Hopkins, D.M., and Hartz, R.W., 1978a; 1978b;

Hopkins, D.M., Hartz, R.W., and Robinson, S.W., 1979; Lewellen, R., $1976 ; 1977$;

Naidu, A.S., 1978; Numendal, Dag, Knoth, J.S., Fisher, I.A., and Fahnestock, R.K., 1978; Owens, E.H., 1977; Reed, J.C., and Slater, J.E., eds., 1974; Short, A.D., and Wiseman, W.J., Jr., 1975;

Skladel, G.W., 1974; Walker, H.J., 1978; Williams, J.R., Carter, L.D., and Yeend, W.E., 1978;

Deltas: Naidu, A., and Mowatt, T.C., 1974; Ritchie, W., and Walker, H.V., 1974; Walker, H.J., 1974; 1976a;

Eolian: Carter, L.D., and Galloway, J.P., 1979a; Carter, L.D., and Robinson, S.W., 1978a;

Fluvial: Boothroyd, J., and Timson, B.S., 1980; Nemeth, E.F., 1977;

General: Detterman, R.L., 1978; Drage, B.T., 1977;

Glaciation: Ellis, J.M., and Calkin, P.E., 1978; French, H.M., 1976; Hamilton, T.D., 1979a; Post, Austin, and Meier, M.F., 1979;

Ice

General: Hardy Associates, (1978) Ltd., 1980;

Sea: Kane, D.L., Carlson, R.F, and Seifert, R.D., 1975; Kovacs, A., and Mellor, M., 1974; Reimnitz, Erk, and Barnes, P.W., 1974; Reimnitz, Erk, Dunton, K., and Barnes, P.W., 1979; Toimi1, L.J., and Grantz, Arthur, 1976; Toimil, L.J., Reimnitz, Erk, and Grantz, Arthur, 1978; Weller, G., 1976;

Lakes: Sellmann, P.V., and others, 1975; Walker, H.J., 1976b; Weller, M.W., and Derksen, D.V., 1979;

Lineaments: Short, A.D., and Wright, L.D., 1974;

Nearshore: Cannon, P.J., 1977; Cannon, P.J., and Rawlinson, S.E., 1978; 1979; Matthews, J.B., 1978; Reimnitz, Erk, Barnes, P.W., Toimil, L.J., and Harden, D., 1976;

Patterned ground: Goldthwait, R.P., 1974; 
GEOMORPHOLOGY (cont'd.)

Periglacial: Washburn, A.L., 1980;

Pingos: Carter, L.D., and Galloway, J.P., 1979a; Galloway, J.P., and Carter, L.D., 1978;

Soils: Alaska Geological Consultants, 1974; Everett, K.R., 1975; 1979;

Goodwin, C.W., 1976; McGaw, R.Q., Outcalt, S.I., and Ng., E., 1978;

Parkinson, R.J., 1978; Reiger, Samuel, Soephoerster, Dale, and Furbish, C.E., 1978; Tedrow, J.C.F'., 1977;

GEOPHYSICAL INVESTIGATIONS (see also Structural Geology)

Gamma Ray Studies: Curtis, S.M., and Rossiter, Richard, 1979; Curtis, S.M., Rossiter, Richard, Ellersieck, I.F., Mayfield, C.F., and Tailleur, I.L., 1979a; 1979b;

General: Bruggers, D.E., and England, J.M., 1979; England, J.M., and Bruggers, D.E., 1979; Giovannetti, D.M., and Bird, K.J., 1978; Gropp, Dora L., 1977; Sweeney, F.J., 1978; Sweeney, F.J., Coles, R.L., DeLaurier, J., Forsyth, D.A., Irving, E., and others, 1978; Tetra Tech, 1980; U.S. Geological Survey, 1980i;

Gravity Surveys: Barnes, D.F., 1976a; 1977b; 1977a; 1977b; Barnes, D.F., Kososki, B.M, Mayfield, C.F., Ruppel, B.D., Robbins, S.L.., and Tailleur, I.L., 1976; Boucher, Gary, 1976; 1977b; Boucher, Gary, Reimnitz, Erk, and Kempema, Ed., 1980; Boucher, Gary, Ruppe1, B.D., Chiburis, E.F., and Dehlinger, Peter, 1974; 1977;

Geyer, H.A., and Tailleur, I.L., 1980; Giovannetti, D.M., and Bird, K.J., 1979; Gutman, S.I., 1980; Scott, W.R., 1979; Kososki, B.A., and Anderson, R.C., 1977; Kososki, B.A., Reiser, H.N., Cavit, C.D., and Detterman, R.L., 1978; Ruppel, B.D., and McHendrie, Graig, 1975; 1976; Sobczak, L.W., 1978;

Heat-flow Studies: Lawver, L.A., Lachenbruch, A.H., and Moses, T.H., Jr., 1979;

Magnetic Surveys: Cady, J.W., 1978; Coles, R.L. Hannaford, W., and Hanes, G.V., 1978; Decker, John and Kar1, Susan, 1977; Gibson, H.A., and Tailleur, I.L., 1980; Hackett, S.W., and Laird, G.M., 1977; Townsend, J.B., 1978; U.S. Geological Survey, 1977c;

Seismic Surveys: Barnes, Peter, Reimnitz, Erk, Toimil, Larry, Maurer, Douglas, and McDowe11, David, 1979; Eittreim, S., and Grantz, A. 1979a; Mertz, R.W., Brooks, L.D., and Lansley, R.M., 1979; Reimnitz, Erk, 1976; Tailleur, I.L., Engwicht, S.E., 1978b; Tetra Tech, 1979; U.S. Geological Survey, 1978c; 1979c; 1980d; 1980e; 1980f; 1980h; Woodward-Clyde Consultants, 1978;

GEOTHERMAL: Kinney, D.M., and Shelton, J.W., eds., 1976; 
HEAVY MINERALS: Luepke, Gretchen, 1975;

\section{HYDROGEOLOGY}

General: Childers, J.M., Kernodle, D.R., and Loeffler, R.M., 1978a, 1979;

Childers, J.M., Sloan, C.E., Meckel, J.P., and Nauman, J.W., 1977;

Dingman, S.L., Barry, R.G., and others, in press; Madison, R.J., 1976;

Oceanographic Institute of Washington, 1979; Peterson, L.A., 1979;

Sloan, C.E., 1977; Walker, H.J., and Harris, M.K., 1976; Woodward-Clyde, Consultants, 1976 ; 1980a; 1980b;

Ground Water: Drahn, R.A., 1976; March, G.D., 1980;

Icings: Hardin, Deborah, Barnes, Peter, and Reinmitz, Erk, 1977; Sloan, C.E., Zenone, Chester, and Mayo, L.R., 1975; 1976;

Kuparuk River: Kane, D.L., Rice, E.F., and Carlson, R.F., 1975;

Lakes: Alexander, V.C., and Miller, M.C., 1976; 1977; Sloan, C.E., and Snyder, R.F., 1978; Williams, J.R., and Yeend, W.E., 1979;

Snow Surveys: Sloan, C.E., Trabant, Dennis, and Glude, William, 1978; 1979;

Stream Studies: Loeffler, R.M., and Childers, J.M., 1978; Scott, K.M., 1979; Craig, P.C., and McCart, P.J., 1975;

Surface Water

Floods: Childers, J.M., 1974; Lamke, R.D., and Jones, S.H., 1980;

Snowmelt studies: Glude, W.E., and Sloan, C.E., 1980;

Streamflow data: Carlson, R.F., 1977; Carlson, R.F, Norton, W.R., and McDougal1, J.C., 1974; Childers, J.M., 1976; Childers, J.M. , Kernodle, D.R., and Loeffler, R.M., 1978a; Jones, S.H., 1978; Still, P.J., 1980a; 1980b; 1980c;

Water Resources: Alaska Division of Lands, 1976; Childers, J.M., and Kernodle, D.R., 1979; Childers, J.M., Nauman, J.W., Kernodle, D.R., and Doyle, P.F., 1978; Environmental Services, Ltd., 1978; Furniss, R.A., and Ward, D.L., 1976; Hartman, C.W., and Finch, S.G., 1977 ;

National Petroleum Reserve in Alaska Task Force, 1978c; Nelson, G.L., 1977; Reger, R.D., 1976; U.S. Geological Survey, $1974 \mathrm{~b} ; 1975 \mathrm{a} ; 1976 \mathrm{~b} ; 1977 \mathrm{~d} ; 1978 \mathrm{e}$;

Water Supply: Puchtler, Bertold, Reid, Barry, and Christianson, Conrad, 1976; Ward, D.L., and Peterson, L.A., 1976;

Water Quality: ADEC, 1979; Nauman, J.W., and Kernodle, D.R., 1977; Slack, K.V., Nauman, J.W., and Tilley, L.J., 1977; Sti11, P.J., 1976;

Waste Water Disposal: $\mathrm{CH}_{2} \mathrm{M}$ Hi11, 1976; Dames and Moore, 1977;

$$
-46-
$$


Bathymetric: Greenberg, Johnathan, Hart, P.E., and Grantz, Arthur, 1979; 1980; Schumacher, G.M., 1976;

Beaufort Sea-Brooks Range: Alpha, T.R., and Gerin, Marybeth, 1.980;

Depth to Basement: Tallleur, I.L., Bird, K.J., and Engwicht, S.E., 1978;

Erosional Hazards: Hartz, R.W., 1978;

General: Alpha, T.R., and Swenson, Phyl1is, 1978; Heezen, B.C., and Tharp, M., 1975;

Geologic: Beikman, H.M., 1978; 1980; Beikman, H.M., and Lathram, E.H., 1976; Brosge, W.P., and Reiser, H.N., 1976; Brosge, W.P., Reiser, H.N., Dutro, J.T., Jr., and Detterman, R.L., 1976; 1977; 1979; Brosge, W.P., Reiser, H.N., Dutro, J.T., Jr., and Nilsen, T.H., 1979; Everett, K.R., Webber, P.J., and Walker, D.A., and others, 1978;

Grybeck, Donald, Beikman, H.M., Brosge, W.P., Tailleur, I.L., and Mul1, C.G., 1977; Mayfield, C.F., Tailleur, I.L., Mu11, C.G., and Sable, E.G., 1978; Norris, D.K., 1978; Plahuta, J.T., 1978; Reiser, H.N., Brosge, W.P., Detterman, R.L., and Dutro, J.T., Jr., 1978;

Geochemical: Cathra1.1, J.B., Detra, D.E., and Cooley, E.F., 1978a; 1978b; 1978c; 1978d; 1978e; Cathra11, J.B., Detra, D.E., and O'Leary, R.M., 1978; Curtis, S.M., Ellersieck, I.F., Mayfield, C.F., and Tailleur, I.L., 1980; Grybeck, Donald, 1977b;

Gravity: Barnes, D.F., 1976c;

Hydrocarbon: Coury, A.B., Hendricks, T.A., and Tyler, T.F., 1978;

Index: Bartsch-Winkler, Susan, 1978a; 1978b; McIntosh, W.L., and Eister, M.F., 1978; Reiser, H.N., Brosge, W.P., DeYoung, J.H., Jr., Marsh S.P., and others, 1979;

Land Status: Tailleur, I.L., Pessel, G.H., Levorsen, J.A., and Engwicht, S.E., 1978;

Mineral: Grybeck, Donald, and DeYoung, J.H., Jr., 1978;

NPRA: Johnson, K.M., 1978;

Paleocurrent: Nilsen, T.H., Moore, T.E., and Brosge, W.P., 1980;

Radiometric age: Wilson, F.H., and Turner, D.L., 1975;

Structural Geology: Pesse1, G.H., Levorsen, J.A., and Tailleur, I.L., 1978a; Pessel, G.H., Tallleur, I.L., and Levorsen, J.A., 1978; Tailleur, I.L., Engwicht, S.E., 1978a;

Subcrop: Tal1leur, I.L., Pesse1, G.H. ${ }_{47-}$ and Engwicht, S.E., 1978; 


\section{SUBJECT}

METEOROLOGY: Brower, W.A., and others, 1977; Brown, Jerry, Haugen, R.K., and Parrish, Scott, 1975; Holmgren, B., Benson, C., and Weller, G., 1975; Moritz, R., 1977; 1979; Oceanographic Services, Inc., 1979b; Rogers, J.C., 1978;

MINERALOGY: Mowatt, T.C., Naidu, A.s., and Veach, Namok, 1974; Naidu, A.S., 1974;

OCEANOGRAPHY and MARINE GEOLOGY (see also geomorphology)

Alaska Continental Margin: Burk, C.A., and Jrake, C.L., eds., 1974; Grantz, Arthur, and Eittreim, S.L., 1977; Grantz, Arthur, Holmes, M.L., and Kososki, B.A., 1975;

Arctic Ocean: Clark, D.L., 1974; Herman, Yvonne, 1977; Vogt, P.R., and Avery, O.E., 1974;

Bathymetry: Parsons, Barry, and Sclater, J.G., 1977;

Beaufort Sea: Aagaard, K., 1976; Aagaard, K., and Haugen, D., 1977; Barnes, Peter, and Garlow, Richard, 1975; Barnes, Peter, Reimnitz, Erk, Drake, D.E., and Toimil, L.J., 1977; Barnes, Peter, Reimnitz, Erk, Kempema, Edward, Minkler, Peter and Ross, Robin, 1980; Barnes, Peter, Reimnitz, Erk, and Ross, Robin, 1980; Barnes, P.W., and Toimil, L.J., 1979;

Chin, H., 1980; Chin, H., Niedoroda, A., and Mangarella, P., 1979; Chin, H., and others, 1979; Dygas, J.A., 1975; Eittreim, S. Grantz, A., and Whitney, O.T., 1979; Henry, R.F., 1975; Henry, R.F., and Heaps, N.S., 1976; Journal of Geophysical Research, 1975;

Mangarella, P. Chin, H., and Niedoroda, A., 1979; Maurer, D.K., Barnes, P.W., and Reimnitz, Erk, 1978; Mountain, D.G., 1974; Mungal1, J.C.H., Whitaker, R.E., and Pace, S.D., 1979; Mungall, J.C.H., and others, 1978;

Reimnitz, Erk, Barnes, P.W., and Kempema, Edward, 1979; Reimitz, Erk, Barnes, Peter, and Maurer, Douglas, 1979; Reimnitz, Erk, Kempema, Edward, koss, Robin, and Minkler, Peter, 1980; Reimnitz, Erk, Maurer, D.K., Barnes, P.W., and Toimil, L.J., 1977; Reimnitz, Erk, and Ross, Robin, 1979;

Roedick, C.A., 1974; U.S. Geological Survey, 1979b;

Beaufort/Chukchi Sea: Aagaard, K., ed., 1978;

Chukchi Sea: Eittreim, S., Grantz, A., and Whitney, O.T., 1977; Garrison, G.R., and Becker, P., 1976; Johnson, R.A., and Dwyer, L.D., 1977;

Continental Shelf: Barnes, P.W., and McDowe11, David, 1978; McManus, D.A., and Creager, J.S., 1975;

General: Barnes, Peter, Leong, Kam, and Gustafson, Charles, 1974; Herman, Yvonne, ed., 1974; Naidu, A.S., Burrell, D.C., Hood,, D.W., and Dygas, J.A., 1975; Oceanographic Services, Inc., 1980d; Oceanweather, Inc., and Sea Ice Consultants, Inc., 1979; 
OCEANOGRAPHY and MARINE GEOLOGY (cont'd.)

Ice: Ahlnas, K., and Wendler, G., 1979; Arctec, Inc., 1980; Barnes, P.W., McDowe11, David, and Reimnitz, Erk, 1978; Barnes, P.W., and Reinnitz, Erk, 1976; 1979; Barnes, Peter, Reimnitz, Erk, Melchior, John, and Toimi.1, Lawrence, 1977;

Barnett, D.G., 1976; Barry, R.G., 1977; Barry, R.G., Montz, R.E., and Rogers, J.C., 1979; Brooks, L.D., 1974; Bruce, H.E., 1976; Campbe11, W.J., and Ramseier, R.O., 1978;

Environmental Research and Technology, 1976; 1979; Gulf Research and Development Co., 1980; Kovacs, A., 1978; Kovacs, A., and Sodhi, D.S., 1979 ;

Oceanographic Services, Inc., 1976; 1978a; 1979a; 1980a; 1980b; 1980c; 1980e; Pelletier, B., 1974;

Reimnitz, Erk, Barnes, P.W., Toimil, L.J., and Melchoir, John, 1977; Reimnitz, Erk, and Dunton, K., 1979; Reimnitz, Erk, and Maurer, D.K., 1979a; Reimnitz, Erk, Toimil, L.J., and Barnes, P.W., 1977; Rogers, J.C., 1977 ;

Sea Ice Consultants, 1976, 1979; Stringer, W.J., 1976; 1979; Stringer, W.J., Barrett, S.A., and Balvin, N., 1977; Wadham, P., 1979; Weeks, W.F., and Kovacs, A., 1979; University of Alaska, 1975b;

Nearshore: Barnes, Peter, Reimnitz, Erk, Smith, Greg, and Melchior, John, 1977; Dames and Moore, 1978; Feder, H.M., Shaw, D.G., and Naidu, A.S., 1976; Matthews, J.B., 1978; Schindler, J., and Walker, H.J., 1975; Truett, J.C., 1978; Tucker, R.W., and Burre11, D.C., 1977;

Sea Floor: Reimnitz, Erk, Rodeick, C.A., and Wolf, S.C., 1974; Reimnitz, Erk, Toimil, L.J., and Barnes, P.W., 1978; Toimil, L.J., 1978; Toimil, L.J., and Grantz, Arthur, 1976;

Sediment Transport: Barnes, D.F., Kososki, B.M., Mayfir1d, C.F., Ruppel, B.D., and others, 1976; Burrell, D.C., 1976; Burre11, D.C., Gosnik, T., and Naidu, A.S, and others, 1976;

Dygas, J.A., and Burrel1, D.C., 1975; Mowatt, T.C., and Naidu, A.S., 1974; Naidu, A.S., 1979; Nelson, Hans, and Creager, J.S., 1977; Roedick, C.A., 1979;

Weather: Reimnitz, Erk, and Maurer, D.A., 1979a;

OROGENY: Bel1, J.S., 1974;

PALEOCLIMATE: Herman, Yvonne, and Hopkins, D.M., 1980;

PALEOGEOGRAPHY: Carter, L.D., Marincovich, Louie, Jr., Brouwers, E.M., and Forester, R.M., 1979; 
PALEONTOLOGY

Ages

Paleozoic: Sando, W.J., 1974;

Ordovician: Carter, Claire, and Laufeld, Sven, 1975; Oliver, W.A., Jr., Merriam, C.W., and Churkin, Michael, Jr., 1975;

Carboniferous: Armstrong, A.K., 1975a; Armstrong, A.K., and Mamet, B.L., 1975; 1977a; Dutro, J.T., Jr., 1979;

Permian: Detterman, R.L., 1978; Rowett, C.L., 1975;

Jurassic: Imlay, R.W., 1976;

Cretaceous: May, F.E., 1979; May, F.E., and Stein, J.A., 1979; Scott, R.A., and Smiley, C.J., 1979; Sliter, W.V., 1979;

Cenozoic: Herman, Yvonne, 1978;

Foraminifera: Echols, R.J., 1974; Lagoe, M.B., 1976a; 1976b; 1978; 1980;

General: Mann, D.M., 1977; Repenning, C.A., 1978; Tasch, P., 1979; Witmer, R.J., 1980;

Lisburne Group: Bird, K.J., 1976;

Sadlerochit Group: Detterman, R.A., and Dutro, J.T., Jr., 1977;

Paleoenvironment: Morgan, A.V., Morgan, Anne, and Carter, L.D., 1979;

PALYNOLOGY: U.S. Geological Survey, 1980b; 1980c;

PERMAFROST

Coastal: Rogers, J.C., 1976; Rogers, J.C., and Morack, J.L., 1978;

Offshore: Barnes, P.W., Reimnitz, Erk, and Drake, D.E., 1976a; Blouin, S.E., Chamberlain, E.J., Sellmann, P.V., and Garfield, D.E., 1979; Blouin, S.E., Chamberlain, E.J., Sellman, P.V., and others, 1979; Brewer, M.C., 1975;

Harrison, W.D., and Osterkamp, T.E., 1977; Hopkins, D.M., 1977; 1979a; Hopkins, D.M., and Hartz, R.W., 1978c; 1978d; Hunter, J.A., and others, 1978; Osterkamp, T.E., and Harrison, W.D., 1976a; 1976b; 1978a; 1978b;

Page, F.W., and Iskandar, I.K., 1978;

Lachenbruch, A.H., and Marsha11, B.V., 1977; 1978; Lewe11en, R., 1974; 1976; 1977; Miller, D.L., and Bruggers, D.E., 1980; Rogers, J.C., 1977; Rogers, J.C., Harrison, W.D., and Shapiro, L., and others, 1975; Rogers, J.C., and Morack, J.L., 1976; 1978; 1980; 
PERMAFROST (Cont'd.)

Offshore: Sellman, P.V., 1977; Sellmann, P.V., and Chamberlain, E.J., 1979; Sellmann, P.V., Chamberlain, E.J., Veda, H.T., and others, 1977;

Sellmann, P.V., Lewellen, R.I., Ueda, H.T., and others, 1976;

University of Alaska, 1975; Vigdorchik, M.E., 1980;

Onshore: Berg, R.L., Brown, Jerry, and Haugen, R.K., 1978; Lawson, D.E., 1979; Scott, K.M., 1978;

PLATE TECTONICS: Boucher, Gary, 1977a; 1978; 1979; Churkin, Michae1, Jr., and Trexler, J.H., Jr., 1980; Geology, 1980; Herron, E.M., Dewey, J.F., and Pitman, W.C., III, 1974; Jones, B.C., 1980b; Newman, G.E., Mu11, C.G., and Watkins, N.D., 1977; Patton, W.W., Jr., and Tailleur, I.L., 1977; Sainsbury, C.L., and Bloomstein, Edward, 1977; Tectonophysics, 1975b;

PETROGRAPHY: Platt, J.B., 1975; Wood, G.V., and Amrstrong, A.K., 1975a;

PE'TROLOGY

General: Nokleberg, W.J., and others, 1979a; 1979b;

Flaxman Fm.: Hopkins, D.M., McDouga11, K., and lielson, R.E., 1978;

Lisburne Group: Armstrong, A.K., and Manet, B.L., 1977b; 1978;

Nanushak Group: Bartsch-Winlkler, Susan, 1979; Mul1, C.G., 1979;

Ophiolites: Patton, W.W., Jr., Tailleur, I.L., Brosge, W.P., and others, 1977.

Sadlerochit Fm.: Detterman, R.L., 1974;

Shublik Fm.: Fraser, G.S., and Clarke, R.t., 1976;

Sedimentary Rocks

Conglomerates: Mayfield, C.F., Tailleur, I.L., Mull, C.G., and Sable, E.G., 1978;

RADIOCARBON DATING: Carter, L.D., and Robinson, S.W., 1978a; Hamilton, T.D., 1979c; Hopkins, D.M., and Robinson, S.W., 1979;

RADIOMETRIC DATING: Turner, D.L., Grybeck, Donald, and Wilson, F.H., 1975; 1978 ;

REMOTE SENSING: Albert, N.R.D., 1978; Albert, N.R.D., Steele, W.C., and Le Compte, J.R., 1978; Amoco Production Co., 1975; Elachi, C., and Bryan, M.L., 1976; Halbouty, M.T., 1976; Hall, D.K., and Bryan, M.L., 1977;

Kovacs, A., and Morey, R.M., 1978; 1979; Lathram, E.H., 1976; Lathram, E.H., and Albert, N.R., 1976; Le Compte, J.R., 1979; Oceanographic Services, Inc., 1978b; Skibitzke, G.W., 1974; Steele, W.C., Le Compte, J.R., and Albert, iv.R.D., 1979i- 
SEDIMENTARY PETROLOGY: Armstrong, A.K., 1975b; Chamberlain, Edwin, 1978; Guldrnzoph, E.C., 1978;

SEDIMENTOLOGY: Armstrong, A.K., and Bird, K.J., 1976a; 1976b; Nilsen, T.H., Moore, T.E., Dutro, J.T., Jr., Brosge, W.P., and Orchard, D.M., 1980;

SEDIMENTATION

Cenozoic: Eittreim, S. Grantz, A., and Whitney, O.T., 1979;

Devonian: Dutro, J.T., Jr., Brosge, W.P., and Reiser, H.N., 1977;

Endicott Group: Donovan, T.J., and Tailleur, I.L., 1975;

Fortress Mountain Fm.: Hunter, R.E., and Fox, J.E., 1976;

General: Armstrong, A.K., 1974; Barnes, P.W., and Reimnitz, Erk, 1974; Clarke, R.H., 1976; Naidu, A.S., and Howatt, T.C., 1974; 1976;

Nanushak Group: Ahlbrandt, T.S., Huffman, A.C., Jr., Fox, J.E., and Pasternack, Ira; 1979;

SEISMICITY: Biswas, N.N., Gedney, L.D., and Huang, P., 1977; Eittreim, S., and Grantz, A., 1977; Gedney, L.D., Biswas, N.N., and Huang, P., and others, 1977; Meyers, H., 1977; Westmiller, R.J., and Forsyth, D.A., 1978;

SPECTROGRAPHY: Cathrall, J.B., Cooley, E.F., Detra, D.E., and Billings, T.M., 1977; Cathrall, J.B., Cooley, E.F., Detra, D.E., and O'Leary, R.M., 1977;

STRATIGRAPHY (see also structural geology)

Barbara Syncline: Huffman, A.C., Jr., 1979;

Beaucoup Formation: Dutro, J.T., JR., Brosge, W.P., Reiser, H.N., and Detterman, R.L., 1979;

Carboniferous: Armstrong, A.K., and Mamet, B.L., 1975; Armstrong, A.K., Mamet, B.L., Brosge, W.P., and Reiser, H.N., 1976;

Carboniferous and Permian: Bird, K.J., 1978c;

Cretaceous: Roehler, H.W., and Stickler, G.D., 1979; Young, F.G., 1975;

Devonian: Nilsen, T.H., Brosge, W.P., Dutro, J.T., and Moore, T.E., 1980;

General: Van de Kamp, P.C., 1979;

Gubik Formation: Williams, J.R., 1979;

Ipewick Formation: Crane, R.C., and Wiggins, V.D., 1976; 
STRATIGRAPHY, (COnt'd.)

Isopach: Bird, K.J., 1978a; 1978b; Eittreim, S., Grantz, A., and Whitney, 0.T., 1978; Pessel, G.H., Levorsen, J.A., and Tailleur, I.L., 1978b; 1978c; 1978d; 1978e; Pesse1, G.H., and Tailleur, I.L., 1978; Pessel, G.H., Tailleur, I.L., and Bird, K.J., 1978a; 1978b; 1978c; 1978d;

Ivishak Formation: Levorsen, J.A., Pessel, G.H., Carter, R.D., and Tailleur, I.L., 1978a; 1978b;

Hope Basin: Eittreim, S., and Grantz, A., 1979b;

Lisburne Group: Armstrong, A.K., 1977; 1975c; Wood, G.V., and Armstrong, A.K., 1975b;

Nanushak Group: Ahlbrandt, T.S., and Huffman, A.C., 1978; Huffman, A.C., and Ahlbrandt, T.S., 1979;

Nomenclature: Alaska Geological Society Newsletter, 1978; Reiser, H.N., Norris, D.K., Dutro, J.T., Jr., and Brosge, W.P., 1978;

Quaternary: Hamilton, T.D., 1980;

Regional: Alaska Geological Society, 1977; Detterman, R.J., Reiser, H.N., Brosge, W.P., and Dutro, J.T., Jr., 1975; Hamilton, T.D., 1978a; Mul1, C.G., Tailleur, I.L., Mayfield, C.F., and Pessel, G.H., 1976;

Sadlerochit Group: Detterman, R.L., 1976b; Mull, C.G., and Tailleur, I.L., 1977 ;

STRUCTURAL GEOLOGY

Arctic Basin: Grantz, Arthur, and Dinter, D.A., 1980b;

Regional Structure: Grantz, Arthur, and Eittreim, S.L., 1979a; Schoennagel, F.H., 1977;

Tectonics: Metz, P.A., 1979; Roeder, Deitrich, and Mul1, C.G., 1978; Watts, A.B., and Ryan, W.B.F., 1976; Yorath, C.J., and Norris, C.K., 1975 ;

Thrust Faulting: Ellerseick, Inyo, Mayfield, C.F., Tailleur, I.L, and Curtis, S.M., 1979;

SURFICIAL GEOLOGY:

General: Hamilton, T.D., 1977; 1978b; 1979d; Hamilton, T.D., and Thorson, R.M., 1976; Hamilton, T.D., and Trexler, J.H., Jr., 1979; Williams, J.R., Yeend, W.E., Carter, L.D., and Hamilton, T.D., 1977; Yeend, Warren, 1978;

Grave1 Removal: Joyce, M.R., 1979; U.S. Dept. of the Interior, Fish and Wildlife Service, 1980; 
TECTONICS: Churkin, Michael, Jr., Nokleberg, W.J., and Huie, Carl, 1979; Grantz, Arthur, and Kirschner, C.E., 1976; Hasegawa, H.S., Cho, C.W., and Bashan, P.W., 1979; Mul1, C.G., and Roeder, D., 1978; 


\section{REFERENCES}

Aagaard, K, 1976, STD mapping of the Beaufort Sea Shelf; in Environmental Assessment of the Alaskan Continental Shelf, v. 1l, Physical oceanography and meteorology: Principal investigator's reports for the year ending March 1976, OCSEAP NOAA/BLM, p. 249-267.

, ed., 1978, Physical Oceanography and meteorology; in Interim synthesis report, Beaufort/Chukchi: OCSEAP, NOAA/BLM p. 56-100.

Aagaard, K. and llaugen U., 1976, Current measurements in the Beaufort Sea, in Annual reports of the Principal investigators, v. 11, Physical Dceanography \& Meteorology: OCSEAP, NOAA/BLM, p. 11-22.

, 1977, Current measurements in possible dispersal regions of the Beaufort Sea; in Principal investigator's reports for the year ending March, 1977; v. 14, Transport: OCSEAP, NOAA/BLM, p. 40-60.

AAPG, 1976, Permo-Triassic reservoirs of Prudhoe Bay field, North Slope, Alaska; in North American oil and gas fields: AAPG Memoir 24, p. 23-50.

ADEC, 1979, Water quality standards: Alaska Deyartment of Environnental Conservation, Feb. 1979, 34 p.

AEIDC, 1977, Bibliography of the environmental and engineering srudies on the Arctic coast and Beaufort and Chukchi Seas, Anchorage, Univ. Alaska, 11 p.

, 1979a, Bibliography and index of inventory and analysis information on the North Slope Borough coastal resource district - Canning River - Kuparuk River: AEIDC, Anchorage, Univ. Alaska, Prepared for the North Slope Borough Borough, Barrow, Ak., 60 p.

, 1976, Bibliography of Naval Petroleum Reserve io. 4, Supplement, Anchorage, Univ. Alaska, AEIDC, 68 p.

, 1979b, Bibliography of products Alaska coastal management program: Office of Coastal Management AEIDC, Univ. Alaska, Anchorage, unpaged, (472 p.)

, 1980, Current research profile for Alaska, 1979: AEIDC, Univ. Alaska, Anchorage, $420 \mathrm{p}$.

, 1979c, Current research profile for Alaska, 1978: AEIDC, Univ. Alaska, Anchorage, computer printout, not published.

, 1978, Current research profile for Alaska, Fifth edition: AEIDC, Univ. Alaska, Anchorage, $523 \mathrm{p}$.

, 1977, Current research profile for Alaska, Fourth edition: AEIDC, Univ. Alaska, Anchorage, $325 \mathrm{p}$.

, 1976, Current Research profile for Alaska, Third edition, AEIDC, Univ. Alaska, Anchorage, $192 \mathrm{p}$.

,1980b, Environmental review of summer construction of gravel islands; Sag Delta No. 7 and No. 8 Stefansson Sound, Alaska: Prepared for Sohio Petroleum Co., Anchorage, Univ. Alaska, 242 p., variously paginated. 


\section{REFERENCES}

Ah1brandt, T.S., 1979a, Introduction to geologic studies of the Nanushuk Group, North Slope, Alaska, in Ahlbrandt, T.S., ed., Preliminary geologic, petrologic and paleontologic results of the study of Nanushuk Group rocks, North Slope, Alaska: U.S. Geological Survey Circular 794, p. 1-4.

, ed., 1979b, Preliminary geologic, petrologic and paleontologic results of the study of Nanushuk Group rocks, North Slope, Alaska: U.S. Geological Survey Circular 794, 163p.

Ahlbrandt, T.S., and Huffman, A.C., 1978; Cretaceous Nanushuk Group, North Slope Alaska in Johnson, K.M., ed., The United States Geological Survey in Alaska; -Accomplishments during 1977: U.S. Geological Survey Circular $772-B$, p. B13-B15.

Ahlbrandt, T.S., Huffman, A.C., Jr., Fox, J.E., and Pasternack, Ira, 1979, Depositional framework and reservoir-quality studies of selected Nanushuk Group outcrops, North Slope, Alaska, in Ahlbrandt, T.S., ed., Preliminary geologic, petrologic and paleontologic results of the study of Nanushuk Group rocks, North Slope, Alaska: U.S. Geological Survey Circular 794, p. 14-31.

Ahlnas, K. and Wendler, G., 1979, Sea ice observations by satellite in the Bering, Chukchi, and Beaufort Sea, in International Conference on Port and Ocean Engineering under Arctic Conditions, Fifth, Trondheim, Norway: v. 1, p. 313-330.

AINA, 1974, The Alaska arctic coast; a background study of available literature: U.S. Army Corps of Engineers, Alaska District, Arctic Institute of North America $551 \mathrm{p}$.

Alaska Consultants, Inc., 1978, North Slope Borough coastal management program, Prudhoe Bay area Draft: Anchorage, Report for the North Slope Borough, $118 \mathrm{p}$.

Alaska Department of Natural Resources, 1979, Finding and decision of the commissioner pursuant to AS.83.05.035.(a)(14) concerning the proposed Beaufort Sea oil and gas lease sale.

Alaska Division of Geological and Geophysical Surveys, 1976, Biennial report, 1974-1975: College, Alaska, 53 p.

Alaska Division of Lands, 1976, Water resources summary: Dept. Natural Resources, Computer printout dated 8/26/76, Fairbanks, Webster Reservoir, ADL File number 67781 .

Alaska Geological Consultants, Inc, 1974, Alaska terrain and soils reconnaissance program; proposed arctic gas pipeline routes Prudhoe Bay to Alaska/Yukon border: for Northern Engineering Services Company, Ltd.

Alaska Geological Society, 1977, North to south stratigraphic correlation section, Beaufort Sea - Prudhoe Bay - Nora no. 1, Arctic slope, Alaska, Alaska Geological Society, Anchorage. 


\section{REFERENCES}

Alaska Geological Society Newsletter, 1978, North Slope stratigraphic nomenclature: Anchorage, Alaska, May issue.

Alaska Information Service, 1980, Gas pipeline 1980 update: Alaska Series, Special reports for management, no. 4, 22 p.

Alaska Oil and Gas Conservation Commission, 1978, In place hydrocarbons determination Kuparuk River formation, Prudhoe Bay area, Alaska: H.K. Van Poollen and Associates, Inc., Littleton, Colorado, 13 p.

, 1980, Three dimensional reservoir study Sadlerochit formation, Prudhoe Bay field: H.K. Van Poollen and Associates, Inc., Littleton, Colorado, $12 \mathrm{p}$.

Albert, N.R.D., 1978, Landsat mosaics of eastern North Slope petroleum province, Alaska, with preliminary interpretation of observed features: U.S. Geological Survey Miscellaneous Field Studies Map, MF-928V, scale 1:500,000.

Albert, N.R.D., Steele, W.C., and LeCompte, J.R., 1978, Landsat color mosaic of Alaska, in Johnson, K.M., ed., The United States Geological Survey in Alaska; Accomplishments during 1977: U.S. Geological Survey Circular $772-B, p . B 1-B 4$.

Alexander, V.C., and Miller, M.C., 1976, Effects of road construction on nearby lakes on Alaska's north slope; Annual progress report May 1, 1975 - Jan 31, 1976: U.S. Energy Research and Development Administration, Fairbanks, Institute of Marine Science, Univ. Alaska, Fairbanks.

, 1977, Effects of the pipeline haul road on nearby ponds and lakes across Alaska's North Slope, Annual progress report to U.S. Energy Research and Development Administration, Univ. Cincinnati, Ohio.

Alpha, T.R., and Gerin, Marybeth, 1980, Oblique map of the Beaufort Sea and the Brooks Range of Alaska: U.S. Geological Survey Open-file Report 80-455.

Alpha, T.R., and Swenson, Phyllis, 1978, Equal-area base map of Alaska and northeast Siberia: U.S. Geological Survey Open-file Report 78-82, 1 sheet, scale 1:5,000,000.

American Petroleum Institute, American Gas Association, and Canadian Petroleum Association, 1974, Reports on proved reserves of crude oil, natural gas liquids, and natural gas in the United States and Canada: New York, American Petroleum Institute.

Amoco Production Co., 1975, Aerial Reconnaissance - Prudhoe Bay-Harrison Bay Point Lay and Kotzebue Sound and ice movement - Prudhoe Bay-Harrison Bay: Anoco Production Co., Security Life Bldg., Denver, Colorado 80202.

Anchorage 0il Scouts Association, 1976, Alaska International 0il Scouts Association yearbook, v.46, part 1. p. 14-19.

Arctec, Inc., 1978, 011 spill response in the nearshore Beaufort Sea: for Arco, Exxon, Shell, and others, Confidential thru May 1, 1982. Cost to next participant $\$ 3,636$. 


\section{REFERENCES}

Arctec, Inc., 1980, Level ice and pressure ridge characteristics during USCGC Polar Star deployment in Bering and Chukchi Seas: for Amoco and others, confidentiality indefinite, Cost to next participant $\$ 21,875$.

Armstrong, A.K., 1974, Carboniferous carbonate depositional models, preliminary 1ithofacies and paleotectonic maps, Arctic Alaska: AAPG Bulletin, v. 58, no. 4., p. $621-645$.

, 1975a, Carboniferous corals of Alaska, a preliminary report: U.S. Geological Survey Professional Paper 823-C, p. 45-57.

, 1975b, Carboniferous tida1-flat deposits of North Flank, northeastern Brooks Range, Arctic Alaska; in Ginsberg, R.N., ed., Tidal deposits; a casebook of recent examples and fossil counterparts: p. 381-386, SpringerVerlag, New York, N.Y.

, 1975c, Stratigraphy and paleocology of Carboniferous corals, Lisburne Group Brooks Range, Arctic Alaska: Bulletin American Paleontology, v. 67, no. 287, p. 17-31.

, 1976b, Carboniferous environments of deposition and facies, Arctic Alaska, in Symposium on recent and ancient sedinentary environments in Alaska: Anchorage, Alaska Geological Society Symposium Proceedings, p. Al-A16.

, 1977, Mississippian microfacies of the Lisburne group, Endicott Mts., Arctic Alaska: U.S. Geological Survey Circular 751-B. p. 18-19.

Armstrong, A.K., and Mamet, B.L., 1974, Carboniferous stratigraphy, Prudhoe Bay State 1 to northeastern Brooks Range, arctic Alaska: AAPG Bulletin, v. 58, P. 646-660

, 1975, Carboniferous biostratigraphy, northeastern Brooks Range, arctic Alaska: U.S. Geological Survey Professional Paper 884, 29 p.

, 1977a, Carboniferous microfacies, microfossils, and corals, Lisburne Group, Arctic Alaska: U.S. Geological Survey Professional Paper 849, 144 p.

, 1977b, Mississippian microfacies of the Lisburne Group, Endicott Moutains, Arctic Alaska, in Blean, K.M., ed., The United States Geological Survey in Alaska: accomplishments during 1976: U.S. Geological Survey Circular 751-B, p. B18-B19.

, 1978, Microfacies of the Carboniferous Lisburne Group, Endicott Mountains, Arctic Alaska, in Stelck, C.R., and Chatterton, B.D., eds., Western and Arctic Canadian biostratigraphy: Geological Association Canada Special Paper 18, p. 333-394.

Armstrong, A.K., Mamet, B.L., Brosge, W.P., and Reiser, H.N., 1976, Carboniferous section and unconformity at Mount Doonerak, Brooks Range, Alaska: AAPG Bulletin v. 60, no. 6, p. 962-972.

Baker, J.,_Behlke, C.E., Brooks, C.R., eds., and others, 1976, Geotechnic evaluation of the proposed Alcan pipeline system in Alaska: U.S. Federal Power Commission, Report 1455-1, 292 p. 


\section{REFERENCES}

Barker, J.C., 1978, Mineral jnvestigations of certain lands in the eastern Brooks Range - A summary report: U.S. Bureau of Mires Open-file Report 63-78, 25 p.

Barnes, D.F., 1976a, Bouguer gravity nap of Alaska: U.S. Geological Survey Openfile Map 76-70, scale 1:2,500,000.

, 1976b, Gravitational evidence for more Alaskan sedimentary basins [abs.]: AAPG Bulletin v. 60 , no. 12 , p. 2174-2175.

, 1976c, New gravity nap of Alaska, in Cobb, E.H., ed., The United States Geological Survey in Alaska; Accomplishments during 1975: U.S. Geological Survey Circular 733, p. 2, 5-6.

, 1977a, Bouguer gravity map of Alaska: U.S. Geological Survey Geophysical Investigations Map GP-913, 1 sheet, scale 1:2,500,000.

, 1977b, Bouguer gravity map of northern Alaska: U.S. Geological Survey Openfile Report 77-166A, 1 sheet, scale 1:1,000,000.

Barnes, D.F., Kososki, B.M., Mayfield, C.F., Ruppel, B.D., Robbins, S.L., and Tailleur, I.L., 1976, Gravity data from Mt. Michelson, Flaxman Island, Demarcation Point, and Barter Island quadrangles, Alaska: U.S. Geological. Survey Open-file Report 76-258, 4 sheets, scale 1:250,000.

Barnes, P.W., Fox, D., and Reimnitz, Erk, 1979, Sediment load carried by seasonal ice off northern Alaska, 1978 [abs.]: GSA Programs with Abstracts, v. 11, no. 7, p. 384 .

Barnes, Peter, and Garlow, Richard, 1975, Surface current observations - Beaufort Sea, 1972; U.S. Geological Survey Open-file Report 75-619 7 p.

Barnes, Peter, Leong, Kam, and Gustafson, Charles, 1974, Map showing distribution of copper, lead, zinc, nercury, and arsenic in the sediments off the coast of northern Alaska: U.S. Geological Survey Miscellaneous Field Studies Map MF-614, 1:3,375,000.

Barnes, P.W., and McDowe11, David, 1978, Inner shelf morphology, Beaufort Sea, Alaska; U.S. Geological Survey Open-file Report 78-785, 4p., map, scale $1: 700,000$.

Barnes, P.W., McDowe11, David, and Reimnitz, Erk, 1978, Ice gouging characteristics; Their changing patterns from 1975-1977, Beaufort Sea, Alaska: U.S. Geological Survey Open-file Report 78-730, 42 p.

Barnes, P.W., and Reimnitz, Erk, 1974, Sedimentary processes on arctic shelves off the northern coast of Alaska; in Reed, J.C., and Slater, J.E., eds., The coast and shelf of the Beaufort Sea: Arlington, Va., The Arctic Institute of North America, Washington, D.C., p. 439-476.

1976, Sediment-ice interaction in the Beaufort Sea, in Cobb, E.H., ed., The United States Geological Survey in Alaska; Accomplishments during 1975; U.S. Geological Survey Circular 733, p. 17-21. 


\section{REFEREINCES}

Barnes, P.W., and Reimitz, Erk, 1979a, Ice gouge obliteration and sediment redistribution event, 1977-1978, Beaufort Sea, Alaska: U.S. Geological Survey Open-file Report 79-848.

, 1979b, Marine environmental problems in the ice covered Beaufort Sea shelf and coastal regions; in Annual report of the principal investigators, $v$. 9, Hazards: OCSEAP, NOAA/BLM, p. 164-267.

, 1980, Geologic processes and hazards on the Beaufort Sea shelf and coastal regions, in Annual reports of the Principal investigators, v. 4, Hazards: OCSEAP NOAA/BLM, p. 257-356.

Barnes, P.W., Carter, D., Drake, D., Hopkins, D., Reimnitz, Erk, and others, 1976, Offshore permafrost studies, Beaufort Sea; in Environmental assessment of the Alaska Continental Shelf: Annual reports of principal investigators for the year ending March, 1976, v. 12, Geology: OCSEAP, NOAA/BLM, p. 485-511.

Barnes, P.W., Reimnitz, Erk, and Drake, D.E., 1977, Geologic processes and hazards of the Beaufort Sea shelf and coastal regions; Quarterly report of the principal investigators: OCSEAP, NOAA/BLM.

, 1976, Marine environmental problems in the ice covered Beaufort Sea shelf and coastal regions; in Environmental assessment of the Alaskan continental shelf, Annual reports of the principal investigators for the year ending March, 1976, v. 12, Geology: OCSEAP, NOAA/BLM, p. 512-676. (Also in 1977 OCSEAP, v. 17, Hazards, p. 1-229.)

Barnes, P.W., Reimnitz, Erk, Drake, D.E., and Toimil, L.J., 1977, Miscellaneous hydrologic and geologic observations on the inner Beaufort Sea shelf, Alaska: U.S. Geological Survey Open-file Report 77-477, 95 p.

Barnes, P.W., Reimnitz, Erk, Kempema, Edward, Minkler, Peter, and Ross, Robin, 1980, USGS Marine geologic studies in the Beaufort Sea, Alaska, 1979; data type, location, and records obtained: U.S. Geological Survey Open-file Report 80-603, 4 p. +3 p1.

Barnes, P.W., Reimnitz, Erk, Melchior, John, and Toimil, Lawrence, 1977, Rates of ice gouging and sediment reworking, Beaufort Sea, Alaska [abs.]: AAPG Bulletin, v. 71 , no. 5, p. 764 .

Barnes, P.W., Reimnitz, Erk, and Ross, Robin, 1980, Nearshore surficial sediment textures - Beaufort Sea, Alaska: U.S. Geological Survey Open-file Report $80-196,41 \mathrm{p}$.

Barnes, P.W., Reimnitz, Erk, Smith, Greg, and Melchior, John, 1977, Bathymetric and shoreline changes, northwestern Prudhoe Bay, Alaska: U.S. Geological Survey Open-file Report 77-161, 15 p. (Also in Northern Engineer, Fairbanks, Univ. Alaska, v. 9, no. 2, p. 7-13.)

Barnes, P.W., Reinnitz, Erk, and Toimil, L.J., 1977, Preliminary results and observations on vibracoring taken on the Beaufort Sea inner shelf, in

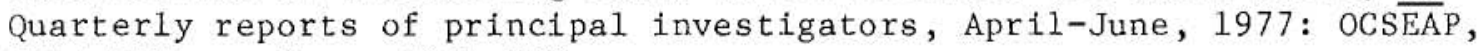
NOAA/BLM, v. 2, p. 5391-569. 


\section{REFERENCES}

Barnes, P.W., Reimnitz, Erk, Toimil, L.J., and Hill, H.R., 1979, Fast-ice thickness and snow depth in relation to oil entrapment potential, Prudhoe Bay, Alaska: U.S. Geological Survey Open-file Report 79-539, 30 p.

Barnes, P.W., Reimnitz, Erk, Toimil, Larry, Maurer, Douglas, and McDowell, David, 1979, Core descriptions and preliminary observations of vibracores from the Alaska Beaufort Sea shelf: U.S. Geological Survey Open-file Report $79-351,12 \mathrm{p}$.

Barnes, P.W., Reimnitz, Erk, Toimil, L.J., and others, 1979, Fast ice thickness and snow depth relationships related to oil entrapment potential, Prudhoe Bay Alaska, in International Conference on Port and Ocean Engineering under Arctic Conditions, Fifth, Trondheim, Norway, Proceedings: v. 3, p. 1205-1226.

Barnes, P.W., and Ross, Robin, 1980, Fall storm, 1979 - A major modifying coastal event, in Barnes, P.W., and Reimnitz, Erk, eds., Geologic processes and hazards of the Beaufort sea shelf and coastal regions: Quarterly reports of the principal investigators, OCSEAP, NOAA/BLM.

Barnes, P.W., and Toimil, L.J., 1979, Maps showing inner shelf circulation patterns, Beaufort Sea, Alaska: U.S. Geological Survey Miscellaneous Field Studies Map MF-1125, 1 sheet.

Barnett, D.G., 1976, A practical method of long-range ice forecasting for the north coast of Alaska: U.S. Navy Fleet Weather Facility, Suitland, Md., Technical Report 1.

Barry, R.G., 1977, Study of climatic effects on fast ice extent and its seasonal decay along the Beaufort-Chukchi coasts, in Enviromnental assessment of the Alaskan continental shelf, v. 14, Transport: OCSEAP, NOAA/BLM, p. 574-743.

Barry, R.G., Montz, R.E., and Rogers, J.C., 1979, The fast ice regions of the Beaufort and Chukchi Sea coasts, Alaska: Cold Regions Science and Technology, v. 1, p. 129-152.

Bartsch-Winkler, Susan, 1978a, Geologic mapping in Alaska, U.S. Geological Survey, post-1930, scales $1: 96,000$ to $1: 250,000$ : U.S. Geological Survey Open-file Report 78-676, 1 sheet, $6 \mathrm{p}$.

, 1978b, Geologic mapping in Alaska, U.S. Geological Survey, post-1930, scales $1: 20,000$ to $1: 63,360$ : U.S. Geological Survey Open-file Report 78-677, 1 sheet, 7 p.

, 1979, Textural and mineralogical study of some surface and subsurface sandstones from the Nanushuk Group, western North Slope, Alaska, in Ahlbrandt, T.S., ed., Preliminary geologic, petrologic, and paleontologic results of the study of Nanushuk Group rocks, North Slope, Alaska: U.S. Geological Survey Circular 794, p. 61-76.

Beikman, H.M., 1978, Preliminary geologic map of Alaska: U.S. Geological Survey, 2 sheets, scale $1: 2,500,000$.

, 1980, Geologic map of Alaska: U.S. Geological Survey, 1:2,500,000. 


\section{REFERENCES}

Beikman, H.M., and Lathram, E.H., 1976, Preliminary geologic map of northern Alaska: U.S. Geological Survey Miscellaneous Field Studies Map MF-789, 2 sheets, scale $1: 1,000,000$.

Bel1, J.S., 1974, Late Paleozoic orogeny in the northern Yukon, in Aitken, J.D., and Glass, D. J., eds., Symposium of the geology of the Canadian arctic, Proceedings: Canada Socjety of Petroleum Geologists and Geological As sociation of Canada, p. 25-38.

Belon, A.E., Miller, J.M., and Stringer, W.J., 1975, Environmental assessment of resource development in the Alaskan coastal zone based on Landsat imagery: NASA Technical memo, $x-58168$ (v. II-B, Coastal zone management: State and local users: user services), p. 242-260.

Berg, R.L., Brown, Jerry, and Haugen, K.K., 1978, Thaw penetration and permafrost conditions associated with the Livengood to Prudhoe Bay road, Alaska: Third International Conference on Permafrost, Proceedings, Edmonton, Alberta, v. 1 , no.3, p. 615-621.

Bird, K.J., 1976a, Environment and time significance of local guide fossils, Lisburne Group, northeast Alaska [abs.]: AAPG Bulletin, v. 60, no. 12, p. 2175 .

1976b, Petroleum potential of the Lisburne Group, in Cobb, E.H., ed., The United States Geological Survey in Alaska; Accomplishments during 1975: U.S. Geological Survey Circular 733, p. 26.

, 1978a, Generalized isopach map of the Endicott Group, eastern North Slope petroleum province, Alaska: U.S. Geological Survey Miscellaneous Field Studies Map MF-928T, I sheet, scale 1:500,000.

,1978b, Generalized isopach map of the Lisburne Group, eastern North Slope petroleum province, Alaska; U.S. Geological Survey Miscellaneous Field Studies Map MF-828S, 1 sheet, scale 1:500,000.

, 1978c, New information on Lisburne Group (Carboniferous and Permian) in Naval Petroleum Reserve Alaska [abs.]: AAPG Bu11, v. 62, no. 5, p. 880.

Bird, K.J., and Andrews, Jack, 1979, Subsurface studies of the Nanushuk Group, North Slope, Alaska, in Ahlbrandt, T.S., ed., Preliminary geologic, petrologic, and paleontologic results of the study of Nanushuk Group rocks, North Slope, Alaska: U.S. Geological Survey Circular 794, p. 32-41.

Bird, K.J., Connor, C.L., Tailleur, I.L., Silbernman, M.L., and Christie, J.L., 1978, Granite on the Barrow arch, northeast NPRA, in Johnson, K.M., ed., The United States Geological Survey in Alaska; Accomplishments during 1977: U.S. Geological Survey Circular 772-B, P. B24-B25.

Bird, K.J., and Jordan, C.F., 1976a, Lisburne Group - Potential major objective of eastern Arctic Slope, Alaska [abs.]: AAPG Bulletin, v. 60, no. 4, p. 649-650.

, 1976b, The Lisburne Group, A potential major hydrocarbon objective of the Arctic Slope, Alaska: U.S. Geological Survey Open-file Report 76-786, $59 \mathrm{p}$. 


\section{REFERENCES}

Bird, K.J., and Jordan, C.F., 1977a, Lisburne Group (Mississippian and Pennsylvanian), Potential major hydrocarbon objective of Arctic Slope, Alaska: AAPG Bulletin, v. 61, no. 9, p. 1493-1512.

, 1977b, Petroleum potential of the Lisburne Group, eastern arctic slope, Alaska: Oil and Gas Journal, v. 75, no.16, p. 90-94.

Biswas, N.N., Gedney, L.D., and Huang, P., 1977, Seismicity studies; (A) Northeast Alaska and (B) Norton and Kotzebue Sounds; Hazards, data management: OCSEAP/ NOAA, v. 18, p. 269-315.

Blean, K. M., 1976, Reports pertaining to Naval Petroleum Reserve №.4 and adjacent areas of northern A.laska prepared by members of the U.S. Geological Survey: U.S. Geological Survey Open-file Report 76-654, 90 p. , ed., 1977, The United States Geological Survey in Alaska; Organization and status of programs in 1977: U.S. Geological Survey Circular 751-A, 66 p.

Blouin, S. E., Chamberlin, E.J., Sellmann, P.V., and Garfield, D.E., 1979, Determining sub-sea permafrost characteristics with a cone penetrometer Prudhoe Bay, Alaska: Cold Regions Science and Technology v. 1, no. 1.

Blouin, S.E., Chamberlain, E.J., Sellman, P.V., and others, 1979, Penetration tests in subsea permafrost, Prudhoe Bay, Alaska: CRREL Report no. 79-7, 45p.

Boothroyd, J., and Timson, B.S., 1980, Fluvial and glacial processes, central Arctic Slope, Alaska [abs.]; in Wirth, P., and others, compiler, Reports of planetary geology program, 1979-1980: NASA Tech. memo, no 81776, p. 277 .

Bottge, R. G., 1975a, Changing economics of Alaska's coals; Paper presented at Alaska Conference on coals, Univ. Alaska, Fairbanks, Oct. 15-17, 1975: in MIRL Report 38, p. 139-149.

1975b, Impact of a natural gas pipeline on mineral and energy development in Alaska: U.S. Bureau Mines Open-file Report 20-75, 177 p., 101 maps. (Also available as National Technical Information Service PB 240 638/AS.).

Boucher, Gary, 1976, Study of the gravity field of the Beaufort Shelf, north coast of Alaska, in Cobb, E.H., ed., The United States Geological Survey in Alaska; Accomplishments during 1975: U.S. Geological Survey Circular 733 , p. 21-23.

, 1977a, Evidence for the rotation of northern Alaska obtained from gravity anomalies [abs.]: EOS American Geophysical Union Transactions, v. 58, no. $12, \mathrm{p} \cdot 1242$.

, 1977b, Gravity measurements on summer sea ice in the Beaufort and Chukchi Seas, 1976: U.S. Geological Survey Open-file Report 77-705, 7 p. , 1979,

, 1978, Rotation of Alaska and the opening of the Canada Basin: U.S. Geological Survey Open-file Report 78-96, 12 p.+ 7 figs. 


\section{REFERENCES}

Boucher, Gary, 1979, Restoration of the Beaufort Sea rifted margin on the basis of gravity anomalies [abs.]: EOS American Geophysical Union Transactions, v. 60 , no. 18. p. 373.

Boucher, Gary, Reimnitz, Erk, and Kempema, E., 1980, Seismic evidence for an extensive gas-bearing layer at shallow depth, offshore from Prudhoe Bay, Alaska: U.S. Geological Survey Open-file Report 80-809, 20 p.

Boucher, Gary, Ruppe1, B.D., Chiburis, E.F., and Dehlinger, Peter, 1977, Map showing free-air gravity anomalies in the southern Beaufort Sea: U.S. Geological Survey Miscellaneous Field Studies Map MF-851, 1 sheet, scale $1: 1,000,000$.

Bowerman, J.N., and Coffman, R.C., 1975, The geology of the Taglu gas field in the Beaufort basin, NWT, in Canada's continental margins and offshore petroleum exploration: Canadian Society of Petroleum Geologists Memoir 4, p. 649-662.

Brewer, M.C., 1975, The seaward extension of permafrost off the northern Alaska coast [abs.]: International Conference on Port and Ocean Engineering under Arctic Conditions, Second, Reykjavik, Iceland, Proceedings, v. 2, no. 3, p. 987-988.

Brooks, L.D., 1974, Ice Scour on northern continental shelf of Alaska, in Reed, J.E., and Slater, J.S., eds., The coast and shelf of the Beaufort Sea: Arlington, Va., The Arctic Institute of North America, p. 355-366.

Brosge, W.P., and Armstrong, A.K., 1977, Lithologic logs of Lisburne Group in Lawrence Livermore Laboratory Drill Holes 1 and 2, Confusion Creek, Chandler Lake quadrangle, northern Alaska; U.S. Geological Survey Open-file Report $77-26,12 \mathrm{p}$.

Brosge, W.P., and Reiser, H.N., 1976, Preliminary geologic and mineral resources maps (excluding petroleum), Arctic National Wildlife Range, Alaska: U.S. Geological Survey Open-file Report 76-539, 4 p., 4 maps, scale 1:500,000.

, 1977a, Chemical analyses of stream-sediment samples from the Table Mountain and Arctic quadrangles, northern Alaska: U.S. Geological Survey Open-file Report 77-29, 5 sheets.

, 1977b, Lead-zinc mineralization at Bear Mountain, southeastern Brooks Range, in Blean, K.M., ed., The United States Geological Survey in Alaska; Accomplishments during 1976: U.S. Geological Survey Circular 751-B, p. B8-B10.

Brosge, W.P., Reiser, H.N., Dutro, J.T., Jr., and Detterrman, R.L., 1976, Reconnaissance geologic map of the Table Mountain quadrangle, Alaska, U.S. Geological Survey Open-file Report 76-546, 2 sheets, scale 1:200,000.

, 1977, Generalized geologic map of the Philip Smith Mountains quadrangle, Alaska: U.S. Geological Survey Open-file Report 77-430, 1 sheet, scale $1: 200,000$. 


\section{REFERENCES}

Brosge, W.P., Reiser, H.N., Dutro, J.T., Jr., and Detterman, R.L., 1979, Bedrock geologic map of the Philip Snith Mountains quadrangle, Alaska: U.S. Geological. Survey Miscellaneous Field Studies Map MF-879B, 2 sheets, scale $1: 250,000$.

Brosge, W.P., Reiser, H.N., Dutro, J.T., Jr., and Nilsen, T.H., 1979, Geologic map of Devonian rocks in parts of the Chandler Lake and Killik River quadrangles, Alaska: U.S. Geological Survey Open-file Report 79-1224, 1 sheet, scale $1: 200,000$.

Brown, Jerry, Haugen, R.K., and Parrish, Scott, 1975, Selected climatic and soil thermal characteristics of the Prudhoe Bay region; in Brown, Jerry, ed., Ecological investigations of the tundra biome in the Prudhoe Bay region, Alaska: Biological papers of the University of Alaska, Fairbanks, Special Report 2, p. 3-11.

Bruce, H.E., 1976, A study plan for the Alaskan continental shelf: Third international conference on port and ocean engineering under arctic conditions: Eairbanks, Univ. Alaska, Institute of Marine Science, Occasional pub. 4, p. $61-80$.

Bruggers, D.E., and England, J.M., 1979, U.S. Geological Survey geotechnical investigation Beaufort Sea, Alaska - 1979: Prepared for the U.S. Geological Survey by Harding-Lawson Associates, Anchorage, v. 1, 2, and 3 .

Buchan, S.H., 1977, Permian-Triassic of Prudhoe Bay Field [abs.]: AAPG Bulletin, v. 61 , no. $3, \mathrm{p} .465$.

Burger, C. and Swenson, L., 1977, Environmental surveillance of gravel removal on the trans-Alaskan pipeline system with recommendations for future gravel mining; Joint State/Federal Fish and Wildlife Advisory team Special Report $13,35 \mathrm{p}$.

Burk, C.A., and Drake, C.L., eds., 1974, The geology of continental margins, Springer-Verlag, New York, 1009 p. (contains the following articles) Structure of the Bering Sea Basins, p. 661-668.

Arctic Ocean margins, p. 753-766.

The ancient continental margin of Alaska, p. 811-816.

Burre11, D.C., 1976, Natural distribution of trace heavy metals and environmental background in three Alaska shelf areas: OCSEAP, NOAA/BLM/BLM, p. 164-201.

, chm., 1975, Proceedings of the third international conference on port and ocean engineering under arctic conditions; Aug. 11-15, 1975, Fairbanks, Alaska, v. 1, no. 3, 686 p.

Burre11, D.C., Dygas, J.A., and Tucker, R.W., eds., 1974, Beach morphology and sedimentology of Simpson Lagoon; in Alexander, V., and others, 1974, Environmental studies of an arctic estuarine system: Fairbanks, Univ. Alaska, Institute of Marine Science, Report R74-1. 


\section{REFERENCES}

Burrell, D.C., Gosink, T., and Naidu, A.S., and others, 1976, Natural distribution of trace heavy metals and enviromnental background in three Alaskan shelf areas; in Principal investigators reports from the year ending March, 1976, Chemistry and microbiology: OCSEAP/ NOAA, v. 10, p. 1-145.

$\mathrm{CH}_{2} \mathrm{M}$ Hill, 1976, Water and wastewater feasibility study for Nuiqsut, Alaska, North Slope Borough, Barrow, Alaska, 83 p.

Cady, J.W., 1978, Aeromagnetic map and interpretation of the Philip Smith Mountains quadrangle, Alaska, U.S. Geological. Survey Miscellaneous Field Studies Map MF879-E, 1 sheet, scale 1:250,000.

Callahan, J.E., 1975, Coal investigations in western Arctic Alaska, in Rao, P.D., ed., Focus on Alaska's coal 175; Alaska coal conference, Fairbanks, Univ. Alaska, Proceedings: MIRL Report no. 37, p. 48-53.

, 1976, Northern Alaska coal investigations, western Naval Petroleum Reserve, No. 4, in Cobb, E.H., ed., The United States Geological Survey in Alaska; Accomplishments during 1975: U.S. Geological Survey Circular $733, \mathrm{p} .30$.

Callahan, J.E., and Sloan, C.E., 1978, Preliminary report on analyses of Cretaceous coals from northwestern Alaska: U.S. Geological Survey Open-file Report 78-319, 29 p.

Calkin, P.E., and Ellis, J.M., 1978, A Neoglacial chronology for the central Brooks Range, Alaska [abs.]: GSA Abstracts with programs, v. 10, no. 7., p. 376 .

Campbell, W.J., and Ramseier, R.o., 1978, Structure and motion of Bering and Okhotsk Sea ice covers by microwave satellite imagery [abs.]: AAPG Bulletin, v. 62 , no. 7 , p. 1211 .

Cannon, P.J., 1979, The environnental geology and geomorphology of the Barrier island lagoon system along the Beaufort Sea coastal plain, in Annual Reports of the principal investigators: v. 16, Hazards, OCS $\overline{E A P} /$ NOAA/BLM, p. 209-248.

Cannon, P.J., and Rawlinson, S.E., 1978, The environmental geology and geomorphology of the barrier island-lagoon system along the Beaufort Sea coastal plain from Prudhoe Bay to the Colville River: Annual reports of the principal investigators, v. 10 Transport, OCSEAP, NOAA/BLM, p. 687-731.

, 1979, The environmental geology and geomorphology of the barrier island-lagoon system along the Beaufort Sea coastal plain from Prudhoe Bay to the Colville River; in Metleff, B.R., ed., Alaska fisheries; 200 years and 200 miles of change: Alaska Science Conference Proceedings, no 29, p. 335-345. (also in 1980 Annual reports of the principal investigators, v.5, Hazards: OCSEAP, NOAA/BLM, p. 619-634.)

Carlson, R.F., 1977, Effects of seasonability and variability of streamflow on nearshore coastal areas; in Annual reports of principal investigators for the year ending March, 1977, v. 14, Transport: OCSEAP, NOAA/BLM/BLM, p. 96-250. 
Carlson, R.F., and Fox, P.M., 1976, A northern snownelt-flood frequency model, Water Resources Research, American Geophysical Union, Washington, D.C. v. 12 , no. 4 , p. 786-794.

Carlson, R.F., Norton, W.R., and McDougall, J.C., 1974, Modeling snowmelt runoff in an arctic coastal plain: Faribanks, Univ. Alaska, Institute of Water Resources, Report 43, 72 p.

Carnes, David, 1980, Alaska's minerals; A look at 2979: Alaska Construction and 0i1, v. 20, no. 1, p. 40-43.

Carter, Claire, and Laufeld, Sven, 1975, Ordovician and Silurian fossils in well cores from North Slope of Alaska: AAPG Bulletin, v. 59, no. 3, p. 457-464.

Carter, L.D., and Galloway, J.P., 1979a, Arctic coastal plain pingos in National Petroleum Reserve in Alaska, in Johnson, K.M., and Williams, J.R., eds., The United States Geological Survey in Nlaska; Accomplishments during 1978; U.S. Geological Survey Circular 804-B, p. B33-B35.

, 1979b, Southward-progressing stabilization of Holocene eolian sand on the western Arctic Coastal Plain, in Johnson, K.M., and Williams, J.R., eds., The United States Geological. Survey in Alaska; Accomplishments during 1978: U.S. Geological Survey Circular 804-B, p. B37-B39.

Carter, L.D., Marincovich, Louie, Jr., Brouwers, E.M., and Forester, R.M., 1979, Paleogeography of a Pleistocene coastline, Alaskan Arctic Coastal Plain, in Johnson, K.M., and Williams, J.R., eds., The United States Geological Survey in Alaska; Accomplishments during 1.978: U.S. Geological Survey Circular $804-B$, p. B39-B41.

Carter, L.D., Repenning, C.A., Marincovich, L.N., Hazel, J.E., Hopkins, D.M., McDougall, Kristin, and Naeser, C.W., 1977, Gubik and pre-Gubik Cenozoic deposits along the Colville River near Ocean Point, North Slope, Alaska, in Blean, K.M., ed., The United States Geological Survey in Alaska;

Accomplishments during 1976: U.S. Geological Survey Circular 751-B, p. B1.2-B14.

Carter, L.D., and Robinson, S.W., 1978a, Eolian Sand and interbedded organic horizons at Kealok Creek on the arctic coastal plain of Alaska; possible regional implications: U.S. Geological Survey Open-file Report 78-320, 26 p.

, 1978b, Radiocarbon-dated episodes of activity and stabilization of large dunes, Arctic coastal plain, Alaska [abs.]: American Quaternary Association, National Conference Abstracts, no. 5, p. 192.

Carter, R.D., Denman, J.M., and Pierpoint, J.G., 1975, Geologic 1iterature on the North Slope of Alaska, 1969-1974: U.S. Geological Survey Open-file Report 75-384, 81 p.

Carter, R.D., and Lantz, R.J., 1978, Development and operation of gas fields in the South Barrow area, in Johnson, K.M., ed., The United States Geological Survey in Alaska; Accomplishments during 1977: U.S. Geological Survey Circular 772-B, p. B29-B30. 
Carter R.D., and Lantz, R.J., 1979, Development and operation of gas fields in the Barrow area, in Johnson, K.M., and Williams, J.R., eds., The United States Geological Survey in Alaska; Accomplishments during 1978: U.S. Geological Survey Circular 804-B, p., B52-B53.

Carter, R.D., Mull, C.G., and Bird, K.J., 1977, Any Prudhoe Bays in Naval Petroleum Reserve no. 4 ?, in Blean, K.M., ed., The United States Geological Survey in Alaska, Accomplishments during 1976: U.S. Geological Survey Circular 751-B, p. B14-B15.

Carter, R.D., Mul1, C.G., Bird, K.J., and Powers, R.B., 1977, The petroleum geology and hydrocarbon potential of Naval Petroleum Reserve No. 4, North Slope, Alaska: U.S. Geological Survey Open-file Report, 77-475, 61 p.

Cathrall, J.B., Cooley, E.F., Detra, D.E., and Billings, T.M., 1977, A listing and statistical summary of spectrographic analyses of heavy mineral concentrate samples for the Philip Smith Mountains quadrangle, Alaska: U.S. Geological Survey Open-file Report 77-426, 70 p.

Cathra11, J.B., Cooley, E.F, Detra, D.E., and O'Leary, R.M., 1977, A listing and statistical summary of spectrographic and chemical analysis of streamsediment and rock samples from the Philip Smith Mountains quadrangle, Alaska: U.S. Geological Survey Open-file Report 77-244, 79 p.

Cathral1, J.B., Detra, D.E., and Cooley, E.F., 1978a, Geochemical maps showing the distribution and abundance of copper in the Philip Smith Mountains quadrangle, Alaska: U.S. Geological Survey Miscellaneous Field Studies Map MF-879G, 1 sheet, scale 1:250,000

, 1978b, Geochemical maps showing the distribution and abundance of lead in the Philip Smith Mountains quadrangle, Alaska: U.S. Geological Survey Miscellaneous Field Studies Map MF-879H, 1 sheet, scale 1:250,000.

, 1978c, Geochemical maps showing the distribution and abundance of silver in the Philip Smith Mountains quadrangle, Alaska: U.S. Goological Survey Miscellaneous Field Studies Map MF-879-J, 1 sheet, scale 1:250,000.

, 1978d, Geochemical maps showing the distribution and abundance of barium in the Philip Smith Mountains quadrangle, Alaska: U.S. Geological Survey Miscellaneous Field Studies Map MF-879K, 1 sheet, scale 1:250,000.

, 1978e, Geochemical maps showing the distribution and abundance of antimony, arsenic, bismuth, cadmium, molybdenum, and tin in the Philip Smith Mountains quadrange, Alaska: U.S. Geological Survey Miscellaneous Field Studies Map MF-879L, 1 sheet, scale 1:250,000.

Cathra11, J.B., Detra, D.E, and O'Leary, R.M., 1978, Geochemical maps showing the distribution and abundance of zinc in the Philip Smith Mountains quadrangle, Alaska: U.S. Geological Survey Miscellaneous Field Investigations Map MF-879I, 1 sheet, scale 1:250,000.

Chamberlain, Edwin, 1978, Overconsolidated sediments in the Beaufort Sea: The Northern Engineer, Univ. Alaska, Fairbanks, v. 10, no. 3, p. 24-29. 


\section{REFERENCES}

Chiburis, E.F., and Dehlinger, Peter, 1974, Free-air gravity anomalies in the Beaufort Sea [abs.]: GSA Abstracts with Programs, v. 6, no. 3, p. 154.

Childers, J.M., 1974, Flood surveys along TAPS route, Alaska: U.S. Geological Survey Water Resources Division Basic Data Report 2-74., 16 p.

Childers, J.M., 1976, Streamflow, channel erosion, and icings along TAPS route, in Cobb, E.H., ed., The United States Geological Survey in Alaska; Accomplishments during 1975: U.S. Geological Survey Circular 733, p. 8.

Childers, J.M., and Kernoldle, D.R., 1979, Water resources of the Noatak River basin, in Johnson, K.M., and Williams, J.R., eds., The United States Geological Survey Circular 804-B, p. B53-B54.

Childers, J.M., Kernodle, D.R., and Loeffler, R.M., 1978a, Hydrogeology of arctic Alaska, in Johnson, K.M., The United States Geological Survey in Alaska; Accomplishments during 1977: U.S. Geological Survey Circular $772-\mathrm{B}, \mathrm{p} . \mathrm{B} 33-\mathrm{B} 34$.

, 1978b, Stream flow and channel erosion investigations along the TAPS route, in Johnson, K.M., ed., The United States Geological Survey in Alaska; Accomplishments during 1977: U.S. Geological Survey Circular $772-B, \mathrm{p} . \mathrm{B} 6-\mathrm{B} 7$.

, 1979, Hydrologic reconnaissance of western Arctic Alaska, 1976, 1977: U.S. Geological. Survey Openfile Report 79-699, 70 p.

Childers, J.M., Sloan, C.E., Meckel, J.P., and Nauman, J.W., 1977, Hydrogeologic reconnaissance of the eastern North Slope, Alaska, 1975: U.S. Geological. Survey Open-file Report 77-492, $65 \mathrm{p}$.

Childers, J.M., Nauman, J.W., Kernodle, D.R., and Doyle, P.F., 1978, Water resources along the TAPS route, Alaska, 1970-74: U.S. Geological Survey Open-file Report 78-137, 136 p.

Chin, H., 1980, Physical/chemical measurements taken in the Beaufort Sea, July/August 1979, in Environmental assessment of the Beaufort Sea, summer 1979: Woodward-Clyde Associates, Anchorage.

Chin, H., Niedoroda, A. and Mangarella, P., 1979, Addendum to 1978 summer environment studies associated with the Prudhoe Bay Dock; physical oceanography and benthic ecology: Draft report to Atlantic Richfield Co. by Woodward-Clyde Associates, Anchorage.

Chin, H., and others, 1979, Environmental studies associated with Prudhoe Bay dock; physical oceanography and benthic ecology: Final report prepared for the Atlantic Richfield Co. by Woodward-Clyde Associates, Anchorage.

Churkin, Michael, Jr., 1975, Basement rocks of Barrow Arch, Alaska, and circumArctic Paleozoic mobile belt: AAPG Bulletin, v. 59, no.3, p. 451-456. 


\section{REFERENCES}

Churkin, Michael, Jr., Huie, Carl, Mayfield, C.F., and Nokleberg, W.J., 1978, Geologic investigations of metallic mineral resources of southern NPRA, in Johnson, K.M., ed., The United States Geological Survey in Alaska; Accomplishments during 1977: U.S. Geological Survey Circular 772-B, p. B15-B17.

Churkin, Michael, Jr., Mayfield, C.F., Theobald, P.K., Barton, Harlan, Nokleberg, w.J., Winkler, G.R., and Huie, Carl, 1978, Geological and geochemical appraisal of metallic mineral resources, southern National Petroleum Reserve in Alaska, U.S. Geological Survey Open-file Report 78-70A, 82 p.

Churkin, Michael, Jr., Nokleberg, W.J., and Huie, Car1, 1979, Collision deformed Paloezoic continental margin, western Brooks Range, Alaska: Geology, v. 7, p. 379-383.

Churkin, Michael, Jr., and Trexler, J.H., Jr., 1980, Circum-Arctic plate accretion-isolating part of a Pacific plate to form the nucleus of the Arctic basin: Earth and Planetary Science Letters, 48(2):356-362.

Clark, A.L., Berg, H.C., Cobb, E.H., Eberlein, G.D., Mackevett, E.M., and Miller, T.P., 1974, Nietal provinces of Alaska: U.S. Geological Survey Miscellaneous Investigations Map I-834, scale 1:5,000,000.

Clark, D.L., 1974, Late Mesozoic and early Cenozoic sediment cores from the Arctic Ocean: Geology, v. 2, no. 1, p. 41-44.

, 1975, Geological history of the Arctic Ocean Basin; in Canada's continental margins, and offshore petroleum explorations: Canadian Society of Petroleum Geologists Memoir 4., p. 501-524.

Clark, D.L., Whitman, R.R., Horgan, K.A., and Mackey, S.D., 1980, Stratigraphy and glacial-marine sediments of the Amerasian Basin, central Arctic Ocean: Boulder, Colorado, Geological Society of Anerican Special Paper 181, 57 p., 8 pls.

Clarke, R.H., 1976, Climatic control of deposition at Prudhoe Bay, Alaska during the late Cenozoioc [abs.]: AAPG Bulletin, v. 60, no. 4, p. 657

Claypool, G.E., and Magoon, L.B., 1980a, Vitrinite reflectance and $\mathrm{C}_{1}-\mathrm{C}_{7}$ hydrocarbon data for Cape Halkett No. 1 well, North Slope, Alaska: U.S. Geological Survey Oil and Gas Investigations Chart OC-97, 1 sheet.

, 1980b, Vitrinite reflectance and $\mathrm{C}_{1}-\mathrm{C}_{7}$ hydrocarbon data for Drew Point No. 1 well, North Slope, Alaska: U.S. Geological Survey Oil and Gas Investigations Chart $0 \mathrm{C}-100,1$ sheet.

, 1980c, Vitrinite reflectance and $\mathrm{C}_{1}-\mathrm{C}_{7}$ hydrocarbon data for North Kalilpik No. I well, North Slope, Alaska: U.S. Geological Survey Oil and Gas Investigations Chart OC-96, 1 sheet.

Cobb, E.H., 1975a, Geological Survey and selected U.S. Bureau of Mines and Alaska Division of Geological and Geophysical Surveys reports and maps on Alaska released during 1974, indexed by quadrangle: U.S. Geological Survey Openfile Report 75-128, 46 p. 
Cobb, E.H., 1975b, Summary of references to mineral occurrences (other than mineral fuels and construction materials) in northern Alaska: U.S. Geological Survey Survey Open-file Report 75-628, 106 p.

, 1976, Geological Survey and selected U.S. Bureau of Mines, and Alaska Division of Geological and Geophysical Surveys reports and maps on Alaska released during 1975, indexed by quadrangle: U.S. Geological Survey Openfile Report 76-332, 95 p.

, 1977, Selected Geological Survey, U.S. Bureau of Mines, and Alaska Division of Geological and Geophysical Surveys reports and maps of Alaska released during 1977, indexed by quadrange,: U.S. Geological Survey Openfile Report 78-171, 115 p.

, 1978, Selected Geological Survey, U.S. Bureau of Mines, and Alaska Division of Geological and Geophysical Surveys reports and maps of Alaska released during 1977, indexed by quadrangle: U.S. Geological Survey Openfile Report 78-283, 96 p.

, 1979a, Alaskan papers and abstracts published in AAPG Bulletin, 19501978, indexed by quadrangle: U.S. Geological Survey Open-file Report 79-1.475, $78 \mathrm{p}$.

1979b, Alaskan papers and abstracts published by the GSA, 1890-1978, indexed by quadrangle: U.S. Ceological Survey Open-file Report 79-1640, $206 \mathrm{p}$.

, 1979c, Selected Geological Survey, U.S. Bureau of Mines, and Alaska Division of Geological and Ceophysical Surveys reports and maps of Alaska released during 1977, indexed by quadrangle: U.S. Geological Survey Openfile Report 79-706, $191 \mathrm{p}$.

, 1980, Selected Geological Survey, U.S. Bureau of Mines, and Alaska Division of Geological and Geophysical Surveys reports and maps of Alaska released during 1979 , indexed by quadrangle: U.S. Geological Survey Openfile Report 81-442, 164 p.

Coleman, J.M., 1976, Coal environments [abs.]: AAPG Bulletin, v. 60, no. 4, p. 658-659.

Coles, R.L., Hannaford, W., and Hanes, G.V., 1978, Magnetic anomalies and the evolution of the Arctic, in Sweeney, J.F., ed., Arctic Geophysical Review Publication: Earth Sciences Branch, Dept. Energy, Mines Resources Canada v. 45, no. 4, p. 54-66.

Collins, R.J., 1974, Petroleum resources and econonics of the Alaskan Arctic: Colorado School of Mines, M.S. Thesis.

Committee on Permafrost, 1975, Opportunities for permafrost-related research associated with the Trans-Alaska Pipeline system: National Academy Science, Washington, D.C., $37 \mathrm{p}$. 
Conwel1, C.N., and Triplehorn, J.M., 1976, High-quality coal near Point Hope, northwestern Alaska: in Short notes on Alaskan Geology, 1976: Alaska Division of Geological and Geophysical Surveys Geological Report 51, p. $31-35$.

Coury, A.B., Hendricks, T.A., and Tyler, T.F., 1978, Map of prospective hydrocarbon provinces of the world, North and South America: U.S. Geological Survey Miscellaneous Field Studies Map MF-1044A, I sheet, scale 1:20,000,000.

, 1979, Bibliography for map of prospective hydrocarbon provinces of the worlc: U.S. Geological Survey Open-file Report 79-201, 88 p.

Craig, P.C., and McCart, P.J., 1975, Classification of stream types in Beaufort Sea drainages between Prudhoe Bay and McKenzie Delta, NWT, Canada: Arctic and Alpine Research, v. 7, no. 2, p. 183-199.

Crane, R.C., and Wiggins, V.D., 1976, Ipewick Formation, significant JurassicNeocomian map unit in northern Brooks Range fold belt [abs.]: AAPG Bulletin, v. 60 , no. 12 , p. 2177 .

Curtis, S.M., Ellersieck, I.F., Mayfield, C.F., and Tailleur, I.L., 1980, Map showing silver, copper, lead, and zinc stream-sediment geochemical anomalies in Misheguk Mountain quadrangle, Alaska: U.S. Geological Survey Open-file Report 80-315, 1 sheet, scale 1:150,000.

Curtis, S.M., and Rossiter, Richard, 1979, Gatnma-ray values in Barrow, Teshekpuk, and Harrison Bay quadrangles, Alaska: U.S. Geological Survey Open-file Report 79-1146, 1 sheet.

Curtis, S.M., Rossiter, Richard, Ellersieck, I.F., Mayfield, C.F., and Tailleur, I.L., 1979a, Gamma-ray values in the Misheguk Mountain region and in parts of Barrow, Teshekpuk, and Harrison Bay quadrangles, Alaska, in Johnson, K.M., and Williams, J.R., eds., The United States Geological Survey in Alaska; Accomplishments during 1978: U.S. Geological Survey Circular $804-B$, p. B14.

, 1979b, Gamma-ray values in the Misheguk Mountain region, northwestern Alaska: U.S. Geological Survey Open-file Report 79-1086, 2 sheets.

Decker, John and Karl, Susan, 1977, Prelininary aeromagnetic map of the Brooks Range and Arctic Slope, Alaska: U.S. Geological Survey Open-file Report 77-166E, 1 sheet, scale 1:1,000,000.

Degenhart, C.E., Griffis, R.J., McOuat, J.F., and Bigelow, C.G., 1978, Mineral studies of the western Brooks Range performed under contract to the U.S. Bureau of Mines, Contract J0155089: U.S. Bureau of Mines Open-file Report $103-78,529$ p. + pl.

Detterman, R.L., 1974, Fence diagram showing lithologic facies of the Sadlerochit Formation, northeastern Alaska: U.S. Geol. Survey Misc. Field Studies Map MF-584. 


\section{REFERENCES}

Detterman, R.L., 1976a, Biostratigraphy of the Permian and Lower Triassic rocks in the Philip Smith Mountains quadrangle, in Cobb, E.H., ed., The United States Geological Survey in Alaska; Accomplishments during 1975: U.S. Geological Survey Circ. 733, p. 32-33.

, 1976b, Lithofacies fence diagram of Sadlerochit Group for Philip Smith Mts. quadrangle and adjacent areas, northeastern Alaska: U.S. Geological Survey Misc. Field Studies Map MF-744.

1978, The Arctic Lowland region potential landform and lifeform National Landmarks: U.S. Geological Survey Open-file Report 78-329, 409 p.

Detterman, R.I., and Dutro, J.T., Jr., 1977, Depositional environment and fauna for a section of the Sadlerochit Group, northeastern Alaska, in Blean, K.M., ed., The United States Geological Survey in Alaska; Accomplishments during 1976: U.S. Geological Survey Circular 751-B, p. B10-B12.

Detterman, R.I., Reiser, H.N., Brosge, W.P., and Dutro, J.T., Jr., 1975, PostCarboniferous stratigraphy, northeastern Alaska: U.S. Geological Survey Professional Paper 886, 46 p.

Detra, D.E., 1977, Delineation of an anomalous lead-zinc area in the Philip Smith Mountains A-2 quadrangle, Alaska: U.S. Geological Survey Open-file Report $77-223,11 \mathrm{p}$.

Dingman, S.L., Barry, R.G., and others, 1980, Climate, snow cover, microclimate and hydrology, in Brown, Jerry, and others, eds., An Arctic Ecosystem; The coastal tundra at Barrow, Alaska: Stroudsburg, Pa., Dowden, Hutchinson and Ross, Chap 2, p. 30-65.

Donovan, I.C., and Singh, S., 1976, Liquefaction criteria for the Trans-Alaska pipeline; in Liquefaction problems in geotechnical engineering: American Society Civil Engineers, New York, U.S. p. 139-167.

Donovan, T.J., and Tailleur, I.L., 1975, Map showing paleocurrent and clast-size data from the Devonian-Mississippian Endicott Group, northern Alaska: U.S. Geological Survey Miscellaneous Field Studies Map MF-692, 1 sheet, scale $1: 2,000,000$.

Dames and Moore, 1978a, Beaufort Sea region natural physical environment: Technical Report 10, Alaska OCS Socioeconomic Studies Program Sponsor: Bureau of Land Management, Alaska Outer Continental Shelf Office, $40 \mathrm{p}$.

Dames and Moore, 1978b, Beaufort Sea region petroleum development scenarios: Technical Report 6, Alaska OCS Socioeconomic Studies Program, Sponsor: Bureau of Land Management, Alaska Outer Continental Shelf office, $387 \mathrm{p}$.

, 1980, Preliminary results hydrodynamic and water quality modeling of Simpson Lagoon and Prudhoe Bay for the ARCO Waterflood Project. Draft report for Cold Regions Research and Engineering Laboratory, Hanover, N.H. 


\section{REFERENCES}

Drage, B.T., 1977, Hydraulic engineering investigation of braided rivers flowing froin the eastern Brooks Range, Alaska: Fairbanks, Univ. Alaska, M.S. Thesis, $88 \mathrm{p}$.

Drahn, R.A., 1976, Report submitted to BP Alaska on the drilling of three water wells in the Kuparuk River, 15 Jan., 1976: Alaska Geological Consultants, Anchorage, $9 \mathrm{p}$.

Drumnond, K.J., 1974, Paleozoic Arctic margins of North America; in Burke, C.A., and Drake, C.L., eds., The geology of continental margins: New York, Springer-Verlag $802 \mathrm{p}$.

Dutro, J.T., Jr., 1978, Potential strata-bound lead-zinc mineralization, Philip Smith Mountains quadrangle, Alaska, in Johnson, K.M., ed., The United States Geological Survey in Alaska; Accomplishments during 1977: U.S. Geological Survey Circular 772-B, B9-B11.

, 1979a, The Mississippian and Pennsylvanian (Carboniferous) systems in the United States - Alaska: U.S. Geological Survey Professional Paper 1110-DD, P. DD1-DD16.

, 1979b, Geology of Alaska bordering the Arctic Ocean, in Stehli, F.G. Nairn, A.E., and Churkin, Michael, eds., Ocean basins and margins; v. 5, The Arctic Ocean: New York, Plenum.

Dutro, J.T., Jr., Brosge, W. P., Lanphere, M.A., and Reiser, H.M., 1976, Geologic significance of Doonerak Structural high, Central Brooks Range, Alaska: AAPG Bulletin, v. 60, no 6, p. 952-961.

Dutro, J.T., Jr., Brosge, W. P., and Reiser, H.N., 1977, Upper Devonian depositional history, central Brooks Range, Alaska, in Blean, K.M., ed., The United States Geological Survey in Alaska: Accomplishments during 1976: U.S. Geological Survey Circular, 751-B, p. B16-B18.

Dutro, J.T., Jr., Brosge, W.P., Reiser, H.N., and Detterman, R.L., 1979, Beaucoup Formation, a new Upper Devonian stratigraphic unit in the central Brooks Range, northern Alaska, in Sohl, N.F., and Wright, W.B., Changes in Stratigraphic nomenclature by the U.S. Geological Survey, 1978: U.S. Geological Survey Bulletin 1482-A, p. A63-A69.

Dutro, J.T., Jr., and Detra, D.E., 1978, Analyses of rock samples from the Hunt Fork Shale and related Upper Devonian rocks, Philip Smith Mountains quadrangle, Arctic Alaska: U.S. Geological Survey Open-file Report 78-559, $7 \mathrm{p}$.

Dygas, J.A., 1975, A study of wind, waves and currents in Simpson Lagoon; in Environmental studies of an arctic estuarine system: Fairbanks, Univ. Alaska Institute of Marine Science, R74-1, p. 15-43.

Dygas, J.A., and Burrell, D.C., 1975, Dynamic sedimentological processes along the Beaufort Sea Coast of Alaska; in Hood, D.W., and Burre11, D.C., eds, Assessment of the Arctic Marine Environment: Fairbanks, Univ. of Alaska, Institute of Marine Science, Occasional Pub. no. 4, p. 189-203. 


\section{REFERENCES}

Echols, R.J., 1974, Benthic foraminifera of the Alaskan shelf and slope of the Beaufort Sea [abs.], in Reed, J.C., and Slater, J.E., eds., The coast and shelf of the Beaufort Sea: Arlington, Va., Arctic Institute of North America, p. 491.

Eckelmann, W.R., DeWitt, R.J., and Fisher, W.L., 1975, Prediction of fluvialdeltaic reservoir geometry, Prudhoe Bay field, Alaska: World Petroleum Congress, Ninth, Proceedings, v. 2, p. 223-227

Eckelmann, W.R., Fisher, W.L., and DeWitt, R.J., 1976, Prediction of fluvialdeltaic reservoir, Prudhoe Bay field, Alaska, in Miller, T.P., ed., Recent and ancient sedimentary environments in Alaska: Alaska Geological Society Symposium, Anchorage, p. B1-B8.

Eittreim, S. and Grantz, A., , 1977, Seismic and tectonic hazards in the Hope Basin and Beaufort Shelf, in Annual Reports of the principal investigators: OCSEAP, NOAA, v. 1.8, p. $22 \overline{6-268}$.

, 1979a, CDP seismic sections of the western Beaufort continental margin: in Keen, C.E., ed., Crustal properties across passive margins:

Tectonophysics, v. 59, p. 251-262.

, 1979b, Stratigraphy and petroleum potential of Hope Basin, southeast Chukchi Sea [abs.]: AAPG Annual Meeting, 54th, Pacific Section, March 1.4-17, 1979, Program, p. 10-11.

Eittreim, S., Grantz, A., and Greenberg, J., 1979, The Barrow submarine canyon system, western Beaufort Sea [abs.]: GSA Abstracts with Programs, v. 11, no. 7, p. 420 .

Eittreim, S., Grantz, A., and Whitney 0.T., 1977, Tectonic imprints on sedimentary deposits in Hope Basin, in Blean, K.M., ed., The United States Geological Survey in Alaska; Accomplishments during 1976: U.S. Geological Survey Circular 751-B, p. 100-103.

, 1978, Isopach maps of tertiary sediments, Hope Basin, southern Chukchi Sea, Alaska: U.S. Geological Survey Miscellaneous Field Studies Map MF-906, scale $1: 1,000,000.1$ sheet.

, 1979, Cenozolc sedimentation and tectonics of Hope Basin, southern Chukchi Sea, in Sisson, A., ed., The relationship of plate tectonics to Alaskan geology and resources: Alaska Geological Society Symposium, 6th, Anchorage, 1977 , p. B1-B11.

Elachi, C. and Bryan, M.L., 1976, Imaging radar observations of frozen Arctic lakes: Remote Sensing Environment, v. 5, no.3, p. 169-175.

Ellerselck, Inyo, Curt1s, S.M., Gruzensky, A.L., Mayfield, C.F., and Tallleur, I.L., 1980, Copper, lead, and zinc in stream-sediment samples from the DeLong Mountains quadrangle, Alaska: U.S. Geologlcal Survey Open-file Report $80-795,3$ sheets, scale 1:63,360. 


\section{REFERENCES}

Ellerseick, Inyo, Mayfield, C.F., Tailleur, I.L., and Curtis, S.M., 1979, Thrust sequences in the Misheguk Mountain quadrangle, Brooks Range, Alaska, in Johnson, K.M., and Williams, J.R., eds., The United States Geological Survey in Alaska; Accomplishments during 1978: U.S. Geological Survey Circular 804-B, p. B8-B9.

Ellis, J.M., and Calkin, P.E., 1978, Glacierization and cirque distribution, Atigun Pass area, Brooks Range, Alaska [abs.]: GSA Abstracts with Programs, v. 10 , no. 2 p. 40 .

Energy Interface Associates, 1979, Technology review of Arctic offshore oil/gas operations: variously paginated, available from U.S. Geological Survey.

Engineering and Mining Journal, 1977, Major lead-zinc-silver discovery is claimed in Alaska's Brooks Range, October, 1977, p.17.

England, J.M., and Bruggers, D.E., 1979, U.S. Geological Survey geotechnical investigations, Beaufort Sea, Alaska - 1979, Supplemental data: Anchorage, Harding-Lawson Associates.

Environmental Research and Technology, 1976, Beaufort Sea ice statistics from satellite, (ERTS-1 Data): Environment Research and Technology, Inc, Concord, Massachusetts.

, 1979, Bering/Chukchi Sea ice statistics from satellite data: contracted by Mobil, Gulf, Exxon, and Sohio-BP, confidential until March 1, 1984, Cost to next participant $\$ 23,550$.

Environmental Services, Ltd., 1978, Management guidelines for water resource development Prudhoe Bay development area: Prepared for the Alaska Department of Natural Resources, 39 p.

Enzer, H., 1976, Alaskan and Canadian Arctic gas; in The outlook for new surces of gas supply: Brophy, J.J., moderator, panel discussion, Institite Gas Technology, Chicago, p. 30-58.

Everett, K.R., 1975, Soil and landform associations at Prudhoe Bay, Alaska; A soils map of the tundra biome area; in Brown, J., ed., Ecological investigations of the Tundra Biome in the Prudhoe Bay region, Alaska: Biological Papers of the University of Alaska, Special Report no. 2, p. 53-59.

, 1979, Evolution of the soil landscape in the sand region of the Arctic Coastal plain as exemplified at Atkasook, Alaska: Arctic, v. 32, p. 207-223.

, 1980, Distribution and properties of road dust along the northern portion of the Yukon River-Prudhoe Bay haul road; in Brown, J., and Berg, P.L., eds., Environmental engineering investigations along the Yukon RiverPrudhoe Bay haul road, CRREL Report 80-19, p. 101-128.

Everett, K.R., Webber, P.J., and Walker, D.A., and others, 1978, A geological mapping scheme for Alaska coastal tundra: International Conference on Permafrost, Proceedings, Edmonton, Alberta, no 3., v.1, p. 359-365. 
REFERENCES

Feder, H.M., Shaw, D.G., and Naidu, A.S., 1976, The arctic coastal environment of Alaska, v. III, The nearshore marine environment in Prudhoe Bay, Alaska: Fairbanks, Univ. Alaska, Institute of Marine Science Report R-76-1, 3 vols.

Federal Energy Administration, 1976, The exploration, development, and production of Naval Petroleum Reserve Number 4: Federal Energy Administration, Strategic Petroleum Reserve Office, Office of Oil and Gas, Report to the Committees on Interior and Insular Affairs of the Senate and the House of Representatives, Washington, D.C.

Federal Energy Regulatory Commission, 1980, Prudhoe Bay project final environmental impact statement: $416 \mathrm{p}$.

Feulner, A.J., and Reed, K.M., 1977, Bibliography of reports by members of the U.S. Geological Survey on the water resources of Alaska, 1870 through 1976: U.S. Geological Survey Open-file Report 77-687, 112 p.

Ficke, E.R., and Ficke, J.F., 1977, Ice on rivers and lakes - A bibliographic essay: U.S. Geological Survey Hater Resources Investigations 77-95, National Technical Information Service $\mathrm{PB}-279528,173 \mathrm{p} \cdot$

Fox, J.E., 1979, A summary of reservoir characteristics of the Nanushuk Group, Umiat test well 11, National Petroleum Reserve in Alaska; in Ahlbrandt, T.S., ed., Preliminary geologic petrologic and paleontologic results of the study of Nanushuk Group rocks, North Slope, Alaska: U.S. Geological Survey Circular 794, p. 42-53.

Fox, J.E., Lambert, P.W., Pitman, J.K., and Wu, C.H., 1979, A study of reservoir characteristics of the Nanushuk and Colville Groups, Umiat test well 11 , National. Petroleum Reserve in Alaska: U.S. Geological Survey Circular 820, $47 \mathrm{p}$.

Fraser, G.S., 1977, Origin of the phosphates of the Shublik Formation, North Slope of Alaska [abs.]: GSA Abstracts with Programs, v. 9, no. 7, p. 980-981.

Fraser, G.S., and Clarke, R.H., 1976, Transgressive-regressive shelf deposition, Shublik Formation, Prudhoe Bay area, Alaska [abs.]: AAPG Bulletin, v. 60, no. 4, p. 672 .

French, H.M., 1976, The periglacial environment: New York, Longman, Inc., 309 p.

Furniss, R.A., and Ward, D.L., 1976, Comparison of water availability for use in construction of proposed gas pipelines on the Alaskan North Slope: Anchorage, Alaska Biological Consultants for El Paso Natural Gas Co., 69 p.

Galloway, J.P., and Carter, L.D., 1978, Preliminary map of pingos in the National Petroleum Reserve in Alaska: U.S. Geological Survey Open-file Report 78-795, 3 sheets, scales 1:500,000.

Garrison, G.R., and Becker, P., 1976, The Barrow Canyon; a drain for the Chukchi Sea: Journal of Geophysical Research, v. 81, p. 4445-4453. 


\section{REFERENCES}

Gedney, L.D., Biswas, N.N., and Huang, P., and others, 1977, Seismicity of northeast Alaska: Geophysical Research Letter, Univ. Alaska, Fairbanks, v.4, no. 5, p. 175-177.

Geology, 1980, Collision-deformed Paleozoic continental margin, western Brooks Range, Alaska, Forum: Geology, v. 8, no. 8, p. 354-367.

Gerin, Marybeth, and Alpha, T.R., 1979, Gazeteer of coastal and offshore features of the Chukchi and Beaufort Seas: U.S. Geological Survey Open-file Report 79-1563, $21 \mathrm{p}$.

Geyer, R.H., 1979, Interpretation of NPRA gravity and aeromagnetics, geologic summary: Stewart Folk and Co., NPRA File 7942.

Gibson, H.A., and Tailleur, I.L., 1980, Map showing relations between aeromagnetic data and geology, southern National Petroleum Reserve in Alaska: U.S. Geological Survey Open-file Report 80-516, 3 sheets, scales 1:250,000, $1: 63,360$.

Giovannett1, D.M., and Bird, K.J., 1978, Geophysical profiles through the Shaviovik-Echooka River region, in Johnson, K.M., ed., The United States Geological Survey in Alaska; Accomplishments during 1977: U.S. Geological Survey Circular 772-B, P. B32-B33.

, 1979, Gravity and magnetic profiles and rock property data for the Shaviovik and Echooka Rivers area, North Slope, Alaska: U.S. Geological Survey Open-file Report 79-1504, 14 p.

Glude, W.E., and Sloan, C.E., 1980, Reconnaissance snow survey of the National. Petroleum Reserve in Alaska, April-May 1979: U.S. Geological Survey WaterResources Investigations $80-49,13 \mathrm{p}$. [Also as National Technical Information Service PB-80-225-006]

Goldthwait, R.P., 1974, Patterned ground other than soil/ice wedges [abs.]: GSA Abstracts with Programs, v. 6, no. 7, p. 759.

Goodwin, C.W., 1976, Process interaction and soil temperature near Point Barrow, A.laska [abs.]: Ann Arbor, Univ. Michigan Ph.D. thesis, $271 \mathrm{p}$. , in Dissertation Abstracts International, v. 37, no. 2, p. 671b-672 b.

Grantz, Arthur, Barnes, P.W., Dinter, D.A., Lynch, M.B., Reimnitz, Erk, and Scott, E.W., 1980, Geolog1c framework, hydrocarbon potential, environmental conditions, and anticipated technology for exploration and development of the Beaufort Shelf north of Alaska: U.S. Geological Survey Open-file Report 80-94, $42 \mathrm{p}$.

Grantz, Arthur, Barnes, P.W., Eittreim, S.L., Reimnitz, Erk, Scott, E.W., Smith, R.A., Stewart, George and Toimil, L.J., 1976, Summary report of the sediments, structural framework, petroleum potential, environmental conditions, and operational considerations of the United States Beaufort Sea, Alaska area: U.S. Geological Survey Open-file Report 76-830, 32 p. 


\section{REFERENCES}

Grantz, Arthur, Boucher, Gary, and Whitney, 0.T., 1976, Possible solid gas hydrate and natural gas deposits beneath the continental slope of the Beaufort Sea, in Cobb, E.H., ed., The United States Geological Survey in Alaska; Accomplishments during 1975: U.S. Geological Survey Circular 733, p. 17.

Grantz, Arthur, and Dinter, D.A., 1980a, Constraints of geologic processes on western Beaufort Sea oil developments: $0 i 1$ and Gas Journal, v. 78, no. 18, p. 304-319.

, 1980b, Implications of geologic structure and regional sedimentation patterns to the rifting geometry of the Arctic Basin [abs.]: AAPG Bulletin, v. $64, p \cdot 714$.

Grantz, Arthur, and Eittreim, S.L., 1977, Geologic framework and related hydrocarbon potential of Beaufort and Chukchi Seas [abs.]: AAPG Bulletin, v. 61, no. $3, \mathrm{p} \cdot 456-466$.

, 1979a, Geologic structure and development of the Alaskan continental margin in the Beaufort Sea [abs.]: EOS, American Geophysical Union Transactions, v. 60 , no. 18 , p. 375 .

, 1979b, Geology and physiography of the continental margin north of Alaska and implications for the origin of the Canada Basin, in Nairn, A.E.M., Stehi, F.G, and Churkin, M., eds., The Ocean basins and margins, v. 5; Geology of the Arctic Ocean Basin and its margins: New York, Plenum. (A1so as U.S. Geological Survey Open-file Report 79-288, 69 p.)

Grantz, Arthur, Eittreim, S.L., and Dinter, D.A., 1979, Geology and tectonic development of the continental margin north of Alaska, in Keen, C.E., ed., Crustal properties across passive margins: Tectonophysics, v. 59, p. 263-291.

Grantz, Arthur, Hanna, W.F., and Ruppel, B.D., 1974, Geologic framework of the Alaska continental terrace in the Chukchi and Beaufort Seas [abs.], in Canada's continental margins and offshore petroleum exploration: Canadian Society of Petroleum Geologists 1974 Symposium, Calgary, Sept. 29 - Oct. 2, 1974, Program and abstracts, p. 48-49.

Grantz, Arthur, Holmes, M.L., and Kososki, B.A., 1975, Geologic framework of the Alaskan continental terrace in the Chukchi and Beaufort Seas: U.S. Geological Survey Open-file Report 75-124, 68 p.

Grantz, Arthur, and Kirschner, C.E., 1976, Tectonic framework of petroliferous rocks in Alaska, in Halbouty, J.T., Maher, J.C., and Lian, H.M., eds., Circum-Pacific energy and mineral resources: AAPG Memoir 25, p. 291-307, (Also as U.S. Geological Survey Open-file Report 75-149.)

Grantz, Arthur, May, S.D., Rupert, J.P., and Whitney, O.T., 1977a, Physiography, geology and mineral resources along the projected United States-Canada boundary in the Arctic Ocean, Administrative report provided for the Office of the Geography, Department of State, June, 1977, 48 p. 


\section{REFERENCES}

Grantz, Arthur, May S.D., Rupert, J.P., and Whitney, U.T., 1977b, Physiography, geology and mineral resources along the projected United States-Soviet Union boundary in the Chukchi Sea and Arctic Ocean: Administrative report provided for the Office of the Geography, Department of State, July, $1977,48 \mathrm{p}$.

Grantz, Arthur, and Mull, C.G., 1978, Preliminary analysis of the petroleum potential of the Arctic National Wildlife Range, Alaska: U.S. Geological Survey Open-file Report 78-489, 20 p.

Grantz, Arthur, Wolf, S.C., Breslau, Lloyd, Johnson, T.C., and llanna, W.F., 1975, Reconnaissance geology of the Chukchi Sea as determined by acoustic and magnetic profiling [abs.], in Forbes, R.B., ed., Contributions to the geology of the Bering Sea Basin and adjacent regions: GSA Special Paper 151 , p. 188.

Gramberg, I.S., and Kulakov, Yu N., 1975, General geologic features and possible oil and gas provinces of the Arctic Basin: in Canada's continental margins and offshore petroleum exploration: Canadian Society of Petroleum Geologists Memoir 4, p. 525-530.

Greenberg, Jonathan, Hart, P.E., and Grantz, Arthur, 1979, Bathymetric map of the continental shelf, slope and rise of the Beaufort Sea north of Alaska: U.S. Geological Survey Open-file Report 79-1313, 6 sheets, scale approx. $1: 250,000$

, 1980, Bathymetric map of the continental shelf, slope and rise of the Beaufort Sea north of Alaska: U.S. Geological Survey Miscellaneous Geologic Investigations Map I-1182-A, scale 1:500,000.

Grider, G.W., Robilard, G.A., and Firth, R.W., Jr., 1978, Environmental studies assiciated with the Prudhoe Bay Dock, Coastal processes and marine benthos: Final report prepared for Atlantic Richfield Co. by Woodward-Clyde Associates, Anchorage, $145 \mathrm{p}$.

, 1977, Environmental studies associated with the Prudhoe Bay Dock; Coastal processes and marine benthos: Final report prepared for Atlantic Richfield Co. by Woodward-Clyde Associates, Anchorage.

Gropp, Dora L., 1977, 1976/77 Geophysical survey of rivers of the Alaskan Arctic coastal plain betweeen Prudhoe Bay and the Canadian border: for Alaskan Arctic Gas Study Company, Anchorage, 83 p.

Grybeck,, Donald, 1977a, Known mineral deposits of the Brooks Range, Alaska: U.S. Geological Survey Open-file report 77-166C, 45 p., map scale 1:1,000,000.

, 1977b, Map showing geochemical anomalies in the Brooks Range, Alaska: U.S. Geological Survey Open-file Report 77-166D, 1 sheet, scale 1:1,000,000.

Grybeck, Donald, Beikman, H.M., Brosge, W.P., Tailleur, I.L., and Mull, C.G., 1977, Geologic map of the Brooks Range, Alaska: U.S. Geological Survey Open-file map 77-166B, 2 sheets, scale 1:1,000,000. 


\section{REFERENCES}

Grybeck, Donald, and DeYoung, J.H., Jr., 1978, Map and tables describing mineral resource potential of the Brooks Range, Alaska: U.S. Geological Survey Openfile Report 78-1-B, 20 sheets, scale $1: 1,000,000$.

Grybeck, Donald, and Nokleberg, W.J., 1979, Metallogeny of the Brooks Range, Alaska, in Johnson, K.M., and Williams, J.R., eds., The United States Geological Survey in Alaska; Accomplishments during 1978: U.S. Geological Survey Circular 804-B, p. B19-B22.

Gryc, George, Mull, C.G., and Tailleur, I.L., 1978, Petroleum exploration of lational Petroleum Reserve in Alaska (NPRA) [abs.]: AAPG Bulletin, v. 62, no 7., p. 1218-1219.

Guldnrzoph, E.C., 1978, Environments of deposition of the Sadlerochit Group, Northeastern NPRA: Prepared for llusky Oil NPRA Operations, Inc., under contract to the U.S. Geological Survey, by Tetra Tech, Inc., Houston, Texas, TC-7916 02, 19 p.

Gulf Research and Development Co., 1980, Beaufort Sea first-year ice features survey: For Gulf and others, confidential until one year after the Beaufort Sea nearshore lease sale or five years after program termination. Cost to next participant, $\$ 30,562$.

Gutman, S.I., 1980, Regional gravity survey of the National Petroleum Reserve in Alaska [abs.]: EOS, Anerican Geophysical Union Transactions, v. 61, no $46 .$, p. 1123 , no. 1171 .

Hackett, S.W., and Laird, G.M., 1977, Aeromagnetic map index of northern Alaska: Alaska Division Geological and Geophysical Surveys Open-file Report 106, 1 sheet, scale $1: 1,000,000$.

Halbouty, M.T., 1976, Application of LANDSAT imagery to petroleum and mineral exploration: AAPG Bull, v. 60, no. 5, p1 745-793.

Ha11, D.K., and Bryan, M.L., 1977, Multispectral remote observations of hydrologic features on the North Slope of Alaska: Greenbelt, Maryland, Goddard Space Flight Center, $38 \mathrm{p}$.

Hamilton, T.D., 1977, Surficial geology of the east-central Brooks Range, in Blean, K.M., ed., the United States Geological Survey in Alaska; Accomplishments during 1976: U.S. Geological Survey Circular 751-B, p. B15-B16.

, 1978a, Late Cenozioc stratigraphy of the south-central Brooks Range, in Johnson, K.M., ed., The United States Geological Survey in Alaska; Accomplishments during 1978: U.S. Geological Survey Circular $804-B$, p. B27-B29.

, 1978b, Surficial geologic map of the Philip Smith Mountains quadrangle, Alaska: U.S. Geological Survey Miscellaneous Field Studies Map MF-879A, 1 sheet, Scale $1: 250,000$. 


\section{REFERENCES}

Hamilton, T.D., 1979a, Late Cenozoic glaciations and erosion intervals, northcentral Brooks Range, in Johnson, K.M., and Williams, J.R. eds., The United States Geological Survey in Alaska; Accomplishments during 1978: U.S. Geological Survey Circular 804-B, p. B27-B29.

, 1979b, Geologic road 1og, Alyeska haul road, Alaska, June-August, 1975: U.S. Geological Survey Open-file Report 79-227, 64 p. +4 pl.

, 1979c, Radiocarbon dates and Quaternary stratigraphic sections, Philip Smith Mountains quadrangle, Alaska: U.S. Geological Survey Open-file Report 79-866, 43 p., 1 pl.

, 1979d, Surficial geologic map of the Chandler Lake quadrangle, Alaska: U.S. Geological Survey Miscellaneous Field Studies Map MR-1121, 1 sheet, scale $1: 250,000$.

, 1980, Quaternary stratigraphic sections with radiocarbon dates, Chandler Lake quadrangle, Alaska: U.S. Geological Survey Open-file Report 80-790, 29 p.

Hamilton, T.1., and Thorson, R.M., 1976, Surficial geologic mapping in the Philip Smith Mountains and Chandalar quadrangles, Brooks Range, in Cobb, E.H., ed., The United States Geological Survey in Alaska; Accomplishments during 1975: U.S. Geological Survey Circular 733, p. 9-10.

Hamilton, T.D., and Trexler, J.H., Jr., 1979, Analyses of surficial deposits, central Brooks Range, Alaska, with a section on field data by T.D. Hamilton, and J.P. McAlpin and a section on laboratory data by J.H. Trexler, Jr.: U.S. Geological Survey Open-file Report 79-228, 95 p.

Hardin, Deborah, Barnes, P.W., and Reimnitz, Erk, 1977, Distribution and character of naleds in northeastern Alaska: U.S. Geological Survey Openfile Report 77-91, 28 p.

Harding-Lawson Associates, 1975, Soil investigation, United States Post Office, Barrow, Alaska: Anchorage.

Harding-Lawson Associates, and $\mathrm{CH}_{2} \mathrm{M} \mathrm{Hi11}, 1979$, Geotechnical investigations; Utilities for Barrow, Alaska: Anchorage, Prepared for the North Slope Borough.

Hardy Associates (1978) Ltd., 1980, Assessment of ice forces, ice over-ride and embankment stability, Prudhoe Bay, waterflood project: Dames and Moore, Anchorage.

Harper, J.R., 1978a, Coastal erosion rates along the Chukchi Sea coast near Barrow, Alaska: Arctic, v. 31, p. 428-433.

Harper, J.R., 1978b, The physical processes affecting the stability of tundra cliff coasts: Baton Rouge, Louisiana State Univ., Ph.D. thesis, 228 p.

Harper, J.R., Owens, E.H., and Wiseman, W.J., Jr., 1978, Arctic beach processes and the thaw of ice-bonded sediments in the littoral zone: International Conference on Permafrost, Proceedings, No.3, v. 1, p. 194-199. 


\section{REFERENCES}

Harrison, G.R., 1980, Production in the Beaufort Sea feasible by mid-1980's: Ocean Industry, v. 15, no. 8, p. 35-36,38,41-42, 44,46,49.

Harrison, W.D., and Osterkamp, T.E., 1977, Subsea permafrost; probing therma1 regime and data analysis, in Annual reports of the principal investigators for the year ending March, 1977, v. 17 Hazards: OCSEAP, NOAA/BLM.

Hartman, C.W., and Finch, S.G., 1977, Alaskan water resources, selected abstracts 1974: Fairbanks, Univ. Alaska, Institute of Water Resources, Report 79, $60 \mathrm{p}$.

Hartz, R.W., 1978, Erosional hazards map of the Arctic coast of the National Petroleum Reserve - Alaska: U.S. Geological Survey Open-file Report 78-406, 8 p., map, scale 1:500,000.

Hartz, R.W., Holden, K., Hopkins, D.M., and Shearer, G., 1979, Location map and summary logs for the U.S. Geological Survey's 1979, Beaufort Sea over the ice drilling program: U.S. Geological Survey Open-file Report 79-1303, 33 p.

Hasegawa, H.S., Cho, C.W., and Basham, P.W., 1979, Seismotectonics of the Beaufort Sea: Canadian Journal of Earth Science, v. 16, no. 4, p. 816-830.

Heezen, B.C., and Tharp, M., 1975, Map of the Arctic Region: World 1:5,000,000, sheet 14, New York, American Geographical Society.

Henry, R.F., 1975, Storn surges: Beaufort Sea Technical Report 19, Victoria, $\mathrm{BC}$, Canada, Department of the Environment.

Henry, R.F., and Heaps, N.S., 1976, Storm surges in the southern Beaufort Sea: Journal of Fisheries Research Board of Canada, v. 33, no. 10.

Herman, Yvonne, 1977, Arctic Ocean Pliocene climate: The deep sea record [abs.]: GSA Abstracts with Prograns, v. 9, no. 7, p. 1020. , 1978, Late Cenozoic paleoceanographic events in the Arctic [abs.]: GSA Abstracts with Programs, v. 10, no 7, p. 420.

, ed., 1974, Marine geology and oceanography of the Arctic seas: SpringerVerlag, New York, 397 p. (contains the following articles)

- Tectonic history of the Arctic Basins: partial solutions and unsolved mysteries, p. 83-118.

-Tectonic setting and Cenozoic sedimentary history of the Bering

Sea, p. 119-140.

-Geological oceanography of the Bering Shelf, p. 141-156.

. Holocene sedimentary framework, east-central Bering Sea continental shelf, p. 157-172.

. Sedimentation in the Beaufort Sea: a synthesis, p. 173-190.

Herman, Yvonne, and Hopkins, D.M., 1980, Arctic oceanic climate in late Cenozoic time: Science, v. 209, no. 4456, p. 557-562.

Herrera, R.C., 1977, Developments in Alaska in 1976: AAPG Bulletin, v. 61, no. 8, p. 11.57-1165. 


\section{REFERENCES}

Herrera, R.C., 1978, Developments in Alaska in 1977: AAPG Bull, v. 62, no. 8, p. $1311-1321$.

Herron, E.M., Dewey, J.F., and Pitman, W.C., III, 1974, Plate tectonics model for the evolution of the Arctic: Geology, v. 2, no. 8, p. 377-380.

Hickock, D.M., 1976, Proposed study plan for the National Petroleum Reserve in Alaska pursuant to section 105 (c) of P.L. 94-528: Anchorage, Univ. Alaska, AEIDC (contract A1835), 95 p., bibliography.

Hiles, R.M., Gryc, George, Dobey, P.L., and Erwin, M.I., 1975, Developments in Alaska in 1974: AAPG Bull, v. 59, no. 8, p. 1311-1321.

Holden, G.D., Katz, D.L., and Hand, J.H., 1976, Hydrate formation in subsurface environments: AAPG Bull, V. 60 , no. 6, p. 981-994.

Holmgren, B. Benson, C. and Weller, G., 1975, A study of the breakup of the Arctic Slope of Alaska by ground, air and satellite observations; in Weller, G., and Bowling, S.A., eds., Climate of the Arctic: AAAS-AMS Symposium Proceedings, Fairbanks, Univ. Alaska, Geophysical Institue p. $358-366$.

Hopkins, D.M., 1977a, Coastal processes and coastal erosion hazards of the Cape Krusenstern archaeological site: U.S. Geological Survey Open-file Report $77-32,17 \mathrm{p}$.

, 1977b, Offshore permafrost studies, Beaufort Sea, in Annual Reports of principal investigators for the year ending March, $\overline{1977}, v .16$, Hazards: OCSEAP NOAA/BLM, p. 396-414.

, ed., 1978, Effects of gravel mining and construction of gravel islands and causeways; in Interim synthesis report: Beaufort/Chukchi, OCSEAP, NOAA, p. 321-334.

, 1979, Offshore pernafrost studies and shoreline history of Chukchi and Beaufort Seas as an aid to predicting offshore permafrost studies, Quarterly Report, October-December, 1979 to OCSEAP, NOAA/BLM, p. 193-249.

Hopkins, D.M., and Hartz, R.W., 1978a, Coastal morphology, coastal erosion, and barrier islands of the Beaufort Sea, Alaska: U.S. Geological Survey Openfile Report 78-1063, 54 p.

, 1978b, Offshore permafrost studies, Beaufort Sea, in Annual reports of the principal investigators for the year ending March 1978: v. 15, Hazards: OCSEAP, NOAA/BLM. p. 75-147.

, 1978c, Shoreline history of Chukchi and Beaufort Seas as an aid to predicting offshore permafrost conditions; in Annual reports of the principal investigators for the year ending March 1978: v. 15, Hazards: OCSEAP, NOAA/BLM, p. 503-574. 


\section{REFERENCES}

Hopkins, D.M., Hartz, R.W., and Robinson, S.W., 1979, Record of a prehistoric storm surge in the Wainwright Inlet-Kuk River area, in Johnson, K.M., and Williams, J.R., eds., The United States Geological Survey in Alaska; Accomplishments during 1978: U.S. Geological Survey Circular 804-B, p. B29-B31.

Hopkins, D.M., McDougall, K., and Nelson, R.E., 1978, The Flaxman formation of northern Alaska; Evidence for an Arctic ice shelf? [abs.]: American Quaternary Association National Conference Abstracts, no. 5, p. 214.

Hopkins, D.M., and Kobinson, S.W., 1979, Radiocarbon dates from the Beaufort and Chikchi Sea coasts, in Johnson, K.M., and Williams, J.R., eds., The United States Geological Survey in Alaska; Accomplishments during 1978: U.S. Geological Survey Circular 804-B, p. B44-B47.

Hoskin, C.M., 1976, Benthos-sedimentary substrate interactions, in Annual reports of the principal investigators for the year ending March, 1976, v. 13, Geology: OCSEAP, NOAA/BLM, p. 285-306.

Huffman, A.C., Jr., 1979, Stratigraphy and petrography of a measured section on the south limb of Barbara Syncline, North Slope, Alaska, in Ahlbrandt, T.S., ed., Preliminary geologic, petrologic, and paleontologic results of the study of Nanushuk Group rocks, North Slope, Alaska: U.S. Geological Survey Circular 794, p. 77-88.

Huffman, A.C., and Ahlbrandt, T.S., 1979, The Cretaceous Nanushuk Group of the western and central North Slope, Alaska, in Johnson, K.M., and Williams, J.R. eds., The United States Geological Survey in Alaska; Accomplishments during 1978: U.S. Geological Survey Circular 804-B, B46-B50.

Hunter, J.A., and others, 1978, Interpretation of sub-seabottom permafrost in the Beaufort Sea by seismic methods; Part I, Seismic refraction methods, Part II Estimating the thickness of the high velocity layer, in International Conference on Permafrost, Third, Edmonton, Alberta, Proceedings: v. 1 , p. 514-526.

Hunter, R.E., and Fox, J.E., 1976, Interpretation of depositional environments in the Fortress Mountain Formation, central Arctic Slope, in Cobb, E.H., ed., The United States Geological Survey in Alaska; Accompiishments during 1975: U.S. Geological Survey Circular 733, p. 30-31.

Imlay, R.W., 1976, Middle Jurassic (Bajocian and Bathonian) ammonites from Northern Alaska: U.S. Geological Survey Professional Paper 854, 22 p.

Jahns, Hans 0. 1979, Production islands, in Technical seminar on Alaskan Beaufort Sea gravel island design: Anchorage, Exxon Co.

Jamison, H.C., Brockett, L.K., and McIntosh, R.A., 1980, Prudhoe Bay - A ten year perspective; in Giant fields of the last decade: AAPG Memoir, in press.

, 1979, Prudhoe Bay a ten year perspective [abs.]: AAPG Bulletin v. 63, no. 4 , p. 699. 


\section{REFERENCES}

Jansons, Uldis, and Baggs, D.W., 1980, Mineral investigations of the Misheguk Mountain and Howard Pass quadrangles, National Petroleum Reserve - Alaska: U.S. Bureau of Mines Open-file Report 38-80, 76 p.

Johnson, K.M., 1978, Map showing slopes and selected geomorphic features, National Petroleum Reserve - Alaska: U.S. Geological Survey Open-file Report 78-206, 1 sheet, scale 1:500,000.

, ed., 1978, The United States Geological Survey in Alaska; Accomplishments during 1977: U.S. Geological Survey Circular 772-B, 115 p.

Johnson, L.A., Sparrow, E.B., Jenkins, T.F., and others, 1980, The fate and effect of crude oil spille don subarctic permafrost terrain in interior Alaska: National Technical Information Service, Springfield, Virginia, $128 \mathrm{p}$.

Johnson, R.A., and Dwyer, L.D., 1977, North Slope Borough water study; a background for planning: Fairbanks, Univ. Alaska, Report to the State of Alaska Deptment of Natural Resources, $115 \mathrm{p}$.

Johnson, S.H., and Chiburis, E.F., 1977, Marine refraction west of Point Barrow, Alaska [abs]: EOS American Geophysical Union Transactions v. 58, no. 3, p. 165 .

Jones, B.C., 1980a, Developments in Alaska in 1979: AAPG Bulletin, v. 64, no. 9, p. $1345-1353$.

, 1979, Developments in Alaska in 1978: AAPG Bulletin, v. 63, no. 8, p. 1211-1222.

, 1980b, Evidence from Canada and Alaska on plate tectonic evoluation of the Arctic Ocean basin: Nature, v. 285, no. 5762, p. 215-217.

Jones, H.P., and Speers, R.G., 1976, Permo-Triassic reservoirs of Prudhoe Bay field, North Slope, Alaska, in Braunstein, Jules, ed., North American oil and gas fields: AAPG Memoir $\overline{24}$, p. 23-50.

Jones, Р.B., Brache, J., and Lentin, J.K., 1980, The geology of the 1977 of fshore hydrocarbon discoveries in the Beaufort-Mackenzie Basin, NWT, Canada: Bulletins of Canadian Petroleum Geology, v. 28, no. 1., p. 81-102.

Jones, S.H., 1978, Streamflow in NPRA, 1977, in Johnson, K.M., ed., The United States Geological Survey in Alaska; Accomplishments during 1977: U.S. Geological Survey Circular 772-B., p. B29.

Journal of Geophysical Research, 1975, Some characteristics of the Beaufort Sea Shelf Current: Journal of Geophysical Research, v. 80, no. 24, p. 3465-3468.

Joyce, M.R., 1979, Gravel removal study in arctic and subarctic Alaskan streams, Terrestrial aspects [abs.]; in Melteff, B.R., ed., Alaska fisheries; 200 years and 200 miles of change: Alaska Science Conference, Fairbanks, proceedings, no. 29 , p. 361 . 


\section{REFERENCES}

Kane, D.L., Carlson, R.F., and Seifert, R.D., 1975, Alaskan arctic coast ice and snow dynamics as viewed by the NOAA satellites: International Symposium on Ice Problems, Third, Hanover, New Hampshire, 18-21. August, 1975, CRREL, p. 567-577.

Kane, D.L., Rice, E.F., and Carlson, R.F., 1975, Hydrology of lower Kuparuk River: Fairbanks, Univ. Alaska Institute of Water Resources Report to Mobile Oil Corp.

Kaiser Engineers, Inc, 1977, Technical and economic feasibility surface mining coal deposits North Slope of Alaska: U.S. Bureau of Mines Open-file Report $153-77,158 \mathrm{p}$.

Kachadoorian, Reuben, Crory, F.E., and Berg, R. L., 1979, Design of airfields in National Petroleum Reserve in Alaska, in Johnson, K.M., and Williams, J.R., eds., The United States Geological Survey in Alaska; Accomplishments during 1978: U.S. Geological Survey Circular 804-B, p. B51-B52.

Kent, Alan, 1977, North Slope oil development depends on big if - Water: Alaska Construction and $0 i 1, \mathrm{v} .18$, no. 3, p. 66-69.

Kinney, D.M., and Shelton, J.W., eds., 1976, Geothermal gradient map of North America: U.S. Geological Survey and AAPG, scale 1:5,000,000.

Kososki, B.A., and Anderson, R.C., 1977, Digital processing of a 24 channel, single-fold seismic reflection line from Naval Petroleum Reserve No. 4, Alaska: U.S. Geological Survey Open-file Report 77-707, 7 p.

Kososki, B.A., Reiser, H.N., Cavit, C.D., and Detterman, R.L., 1978, A gravity study of the northern part of the Arctic National Wildlife Range, Alaska: U.S. Geological Survey Bulletin 1440, 21 p.

Kovacs, A., 1978, Recent ice observations in the Alaska Beaufort Sea federalstate lease area: Univ. Alaska, Fairbanks, Northern Engineer, v. 10, no. 3, p. $7-12$.

Kovacs, A., and Mellor, M., 1974, Sea ice morphology and ice as a geologic agent in the southern Beaaufort Sea; in Reed, J.C., and Slater, J.E., eds., The coast and shelf of the Beaufort Sea: Arlington, Virginia, Arctic Institute of North America p. 113-161.

Kovacs, A. and Morey, R.M., 1978, Remote detection of massive ice in permafrost along the Alyeska pipeline and the pump station feeder gas pipeline; in Pipelines in adverse environments: American Society of Civil Engineers Pipeline Division Specialty Conference, Proceedings, p. 268-279. ,1979, Remote detection of a fresh water pool of the Sagavanirktok River Delta, Alaska: Arctic, v. 32, no. 2, p. 161-164.

Kovacs, A. and Sodhi, D.S., 1979, Ice pile-up and ride-up on arctic and subarctic beaches: Conference on Port and Ocean Engineering under Arctic conditions, Fifth, Trondheim, Norway, Norwegian Institute of Technology. 


\section{REFERENCES}

Kreig, R.A., and Reger, R.D., 1976, Preconstruction terrain evaluation for the trans-Alaskan pipeline project; in Coates, D.R., ed., Geomorphology and engineering: Stroudsburg, $\mathrm{Pa} ., \mathrm{Dow} d e n$, Hutchinson and Ross, Inc., p. 55-76.

LGL Limited, 1979, Barrier island-lagoon ecological process studies modeling workshop, Summaries of reports by principal investigators: Seattle, Washington, Workshop held April 24-25, 1979.

La Belle, J.C., 1976, Fill materials between Barrow and Colville Kiver, northern Alaska: Fairbanks, Univ. Alaska, Institute of Marine Science Occasional Publication 4, p. 161-172.

Lachenbruch, A.H., and Marshal1, B.V., 1977, Sub-sea temperatures and a simple tentative model for offshore permafrost at Prudhoe Bay, Alaska: U.S. Geological Survey Open-file Report 77-395, 54 p.

, 1978, A simple target model for offshore permafrost at Prudhoe Bay, in Johnson, K.M., ed., The United States Geological Survey in Alaska; Accomplishments during 1977: U.S. Geological Survey Circular 772-B, p. B 30-B32.

Lagoe, M.B., 1979, Modern benthic foraminifera from Prudhoe Bay, Alaska: Journal of Paleontology, v. 53, no. 2, p. 258-262.

Lagoe, M.B., 1976a, Quantitative distributional patterns of Recent benthic Eoraminifera; Central Arctic Ocean [abs.]: GSA Abstracts with Programs, v. 8 , no. 6, p. 968-969.

, 1976b, Species diversity of deep-sea benthic Foraminifera from the central Arctic Ocean: GSA Bulletin, v. 87, no. 12, p. 1678-1683.

, 1978, Recent benthonic foraminiferal biofacies in Arctic Ocean [abs.]: AAPG Bulletin, v. 62, no. 11, p. 2357.

, 1980, Recent Arctic foraminifera; an overview, in Field, M.E., and others, eds., Quaternary depositional environments of the Pacific Coast, Pacific Coast Paleogeography Symposium: Society of Economic Paleontologists and Mineralogists, Pacific Section, Fourth, Los Angeles, California p. 33-42.

Lynch, D.F., Johanson, N.I., and Lambert, C. Jr., and others, 1976, Constraints on the development of coal mining in Arctic Alaska based on review of Eurasian Arctic practices: Fairbanks, Univ. Alaska, MIRL, for U.S. Bureau of Mines Open-file Report 41-78, 219 p.

Lyle, W.M., Palmer, I.F., Jr., Bolm, J.G., and Maxey, L.R., 1980, Post-early Triassic formations of northeastern Alaska and their petroleum reservoir and source-rock potential: Alaska Division of Geological and Geophysical Surveys, Geologic Report 76, 100 p., 41. p1.

Lamke, R.D., and Jones, S.H., 1980, Flood-prone area maps at three sites along the trans-Alaska Pipeline, Alaska: U.S. Geological Survey Open-file Report $80-209,14 \mathrm{p}$. 


\section{REFERENCES}

Lange, I.M., and others, 1980a, Isotropic geochemistry of stratiform zinc-leadbarium deposits Red Dog Creek and Drenchwater Creek areas, Northwestern Brooks Range, Alaska: Presented at GSA Cordilleran Section Meeting, Corvallis, Oregon, May, 1981.

Lange, I.M., and others, 1980b, Geochemistry of volcanogenic zinc-lead-barium deposits, northwestern Brooks Range, Alaska [abs.]: GSA Abstracts with Programs, v. 12, p. 116.

Larminie, F.G., 1977, New oil and gas provinces; North Sea and Alaska; in Our Industry Petroleum: London, British Petroleum Company Limited, Chapter 8, p. $150-172$.

Lathram, E.H., 1976, Clues to geologic structure possibly indicating oil and gas sources, in ERTS-1, a new window on our planet: U.S. Geological Survey Professional Paper 929 p. 99-101.

Lathram, E.H., and Albert, N.R., 1976, Significance of space image linears in Alaska: Utah Geological Association Publication 5, International Conference on New Basement Tectonics, First, Proceedings, p.11-26.

Lawson, D.E., 1979, Human-induced thermokarst processes at East Oumalik, northern Alaska [abs.]: GSA Abstracts with Programs, v. 11, no. 7, p. 463.

Lawver, L.A., Lachenbruch, A.H., and Moses, T.H., Jr., 1979, Status of regional. heat-flow studies in Alaska, in Johnson, K.Ri., and Williams, J.R., eds., The United States Geological Survey in Alaska; Accomplishments during 1978: U.S. Geological Survey Circular 804-B, p. B5-B7.

Le Compte, J.R., 1979, Map showing interpretation of Landsat imagery of the Philip Smith Mountains quadrangle, Alaska: U.S. Geological Survey Miscellaneous Field Studies Map MF-879F, 2 sheets, scale 1:250,000.

Levorsen, J.A., Pessel, G.H., Carter, R.D., and Tailleur, I.L., 1978a, Generalized isopach map of the Ivishak formation, eastern North Slope petroleum province, Alaska: U.S. Geological Survey Miscellaneous Field Studies Map MF-928Q, 1 sheet scale 1:500,000.

Levorsen, J.A., Pessel, G.H., and Tailleur, I.L., 1978b, Generalized isopach map of the Ledge Sandstone Member of the Ivishak Formation, eastern North Slope petroleum province, Alaska: U.S. Geological Survey Miscellaneous Field Studies Map MF-928P, 1 sheet, scale 1:500,000.

Lewellen, R., 1974, Offshore permafrost of Beaufort Sea, Alaska, in Reed, J.C., and Slater, J.E., eds., The Coast and shelf of the Beaufort Sea, Alaska: Arlington, Virginia, Arctic Institute of North America, p. 417-426.

, 1976, Driller's field notes subsea permafrost program, Prudhoe Bay, Alaska, March to May, Outer Continental Shelf Program: Arctic Research, P.0. Box 2435, Littleton, Colorado. 


\section{REFERENCES}

Lewellen, R.I., 1976, A study of Beaufort Sea coastal erosion, northern Alaska, in Annual reports of the principal investigators for the year ending March, 1976, V. 13, Geology, OCSEAY, NOAA, p. 417-427.

, 1977a, Driller's field notes subsea permafrost program, Prudhoe Bay, Alaska, March to May, Outer Continental Shelf Program: Arctic Research, P.0. Box 2435, Littleton, Colorado.

, 1977b, A study of Beaufort Sea coastal erosion, northern Alaska, in Annual reports of principal. investsigators for the year ending March, 1977: V. XV, Transport, OCSEAP, NOAA, p. 407-434.

Loeffler, R.M., and Childers, J.M., 1978, Channel erosion surveys along the TAPS route, Alaska, 1977: U.S. Geological Survey Open-file Report 78-61l, $90 \mathrm{p}$.

Lowel1, J.D., 1976, Geology and estinated recoverable gas reserves of the North Slope (onshore) of Alaska: Testimony at a hearing of the Federal Power Comnission, July 13, 1976, docket nos. CP 75-96 et al. and 76-433, et al., Washington, D.C.

Luepke, Gretchen, 1975, Heavy-mineral trends in the Beaufort Sea: U.S. Geological Survey Open-file Report 75-667, 29 p.

Madison, R.J., 1976, Hydrological studies for the Alaskan Air Command, in Cobb, E.H., ed., The United States Geological Survey in Alaska; Accomplishments during 1975: U.S. Geological Survey Circular 733, p. 30.

Magoon, L.B., and Claypool, G.E., 1978, Organic geochemistry of rocks from three NPRA wells, in Johnson, K.M., ed., The United States Geological Survey in Alaska; Accomplishments during 1977: U.S. Geological Survey Circular 772-B, p. B25-B26.

, 1979a, Hydrocarbon source potential of the Nanushuk Group and the Torok Formation, a preliminary report, in Ahlbrandt, T.S., ed., Preliminary geologic, petrologic, and paleontologic results of the study of Nanushuk Group rocks, North Slope, Alaska: U.S. Geological Survey Circular 794, p. 54-60.

, 1979b, Two oi.1 types on the North Slope of Alaska - implications for future exploration: U.S. Geological Survey Open-file Report 79-1649, 13 p. 10 figs.

, 1980a, Vitrinite reflectance and $C_{1}-C_{7}$ hydrocarbon data for Atigaru Point No. 1 well, North Slope, Alaska: U.S. Geological Survey $0 i 1$ and Gas Investigations Chart 98, 1 sheet.

, 1980b, Vitrinite reflectance and $C_{1}-C_{7}$ hydrocarbon data for South Barrow Nos. 14, 16, 17, and 19 wells, North Slope, Alaska: U.S. Geological Survey Oil and Gas Investigations Chart OC-99, 1 sheet.

, 1980c, Vitrinite reflectance and $\mathrm{C}_{1}-\mathrm{C}_{7}$ hydrocarbon data for South Harrison Bay No. 1 well, North Slope, Alaska: U.S. Geological Survey 0il and Gas Investigations Chart OC-93, 1 sheet. 


\section{REFEREITCES}

Magoon, L.B., and Claypool, G.E., 1980d, Vitrinite reflectance and $\mathrm{C}_{1}-\mathrm{C}_{7}$ hydrocarbon data for the South Simpson No. 1 well, North Slope, Alaska: U.S. Geological. Survey $0 i 1$ and Gas Investigations Chart OC-92, 1 sheet.

, 1980e, Vitrinite reflectance and $\mathrm{C}_{1}-\mathrm{C}_{7}$ hydrocarbon data for W.T., Foran No. 1. wel1, North Slope, Alaska: U.S. Geological Survey 0 il and Gas Investigations Chart OC-94, 1 sheet.

, 1980f, Vitrinite reflectance and $C_{1}-C_{7}$ hydrocarbon data for West Fish Creek No. 1 well, North Slope, Alaska: U.S. Geological Survey Oil and Gas Investigations Chart OC-95, 1 sheet.

Mangarella, P., Chin, H., and Niedoroda, A., 1979, Under-ice water conditions in the Beaufort Sea relative to the proposed waterflood discharge, in Environmental studies of the Beaufort sea - Winter, 1979: Report prepared for Prudhoe Bay Unit by Woodward-Clyde Associates, Anchorage, 251 p.

Mann, D.M., 1977, Shelled benthic fauna of the eastern Chukchi Sea; U.S. Geological. Survey Open-file report 77-672, 112 p.

March, G.D., 1980, Evidence for suprapermafrost groundwater blockage, Prudhoe Bay oilfield, Alaska, in Short Notes on Alaskan Geology, 1979-80: Alaska Division of Geological and Geophysical Surveys Geologic Report 63, p. 29-32.

Martin, G.C., and Callahan, J.E., 1978, Preliminary report on the coal resources of the National Petroleum Reserve in Alaska: U.S. Geological Survey Openfile Report 78-1033, 23 p., 2 pl., scale 1:500,000.

Mast, R. F., McMullin, R.H., Bird, K.J., and Brosge, W.P., 1980, Resource appraisal of undiscovered oil and gas resources in the William O. Douglas Arctic Wildlife Range: U.S. Geological Survey Open-file Report 80-916, $62 \mathrm{p}$.

Matthews, J.B., 1978, Characterization of the nearshore hydrodynamics of an arctic barrier island-lagoon system, in Annual reports of principal. investigators for the year ending March, 1978, v. 10, Transport: OCSEAP, NOAA. p. 607-627.

, 1979, Characterization of the nearshore hydrodynamics of an arctic barrier island lagoon system, Annual report, 1 April - 31 March, 1979: OCSEAP, NOAA/BLM, Research Unit 526-77.

Maurer, D.K., Barnes, P.W., and Reimnitz, Erk, 1978, U.S. Geological Survey marine geologic studies in the Beaufort Sea, Alaska, 1977: Data type, location and records obtained: U.S. Geological Survey Open-file Report 78-1066, 3 p., 4 p1.

May, F.E., 1979, Dinoflagellate and acritarch assemblages from the Nanushuk Group (Albian-Cenomanian) and the Torok Formation (Albian), Umiat test wel1 11, National Petroleum Reserve in Alaska Northern Alaska, in Ahlbrandt, T.A., ed., Preliminary geologic, petrologic, and paleontologic results of the study of Nanushuk Group rocks, North Slope, Alaska: U.S. Geological Survey Circular 794, p. 113-127. 


\section{REFERENCES}

May, F.E., and Stein, J.A., 1979, Dinoflagellate and acritarch assemblages from the Grandstand Formation (middle to upper Albian) of the Nanushuk Group, Simpson Core Test 25, National Petroleum Reserve in Alaska, northern Alaska, in Ahlbrandt, T.S., ed., Preliminary geologic, petrologic, and paleontologic results of the study of Nanushuk Group rocks, North Slope, Alaska: U.S. Geological Survey Circular 794, p1. 128-145.

Mayfield, C.F., Curtis, S.M., Ellersieck, I.F., and Tailleur, I.L., 1979a, The Ginny Creek zinc-lead-silver and Nimiuktuk barite deposits, northwestern Brooks Range, Alaska, in Johnson, K.M., and Williams, J.R., eds., The United States Geological Survey in Alaska; Accomplishments during 1978: U.S. Geological Survey Circular 804-B, B11-B12.

Mayfield, C.F., Tailleur, I.L., Mull, C.G., and Sable, E.G., 1978, Bedrock geologic map of the south half of National Petroleum Reserve in Alaska: U.S. Geological Survey Open-file Report 78-70B, 2 sheets, scale 1:500,000.

Mayfield, C.F., Tailleur, I.L., Mull, C.G., and Silberman, M.L., 1978, Granitic clasts from Lower Cretaceous conglomerate in the Northwestern Brooks Range, in Johnson, K.M., ed., The United States Geological Survey in Alaska; Accomplishments during 1977: U.S. Geological Survey Circular 772-B, p. B11-B13.

McCaslin, J.C., 1977, Pet-4 drilling activity to revive in 1978: $0 i 1$ and Gas Journal, v. 75 , no 49 , p. 91.

McGaw, R.W., Outcalt, S.I., and Ng, E., 1978, Thermal properties and regime of wet tundra soils at Barrow, Alaska: International Conference on Pernafrost, Third, Edmonton, Alberta, Proceedings: v. 1, no. 3, p. 47-53.

McGee, D.L., and $0^{\prime}$ Connor, K.M., 1975, Mineral resources of Alaska and the impact of Federal land policies on their availability - Coal: Alaska Division of Geological and Geophysical Surveys Open-file Report AOF-51, 26 p.

McIntosh, Ron, 1977, Prudhoe Bay unit operating plan, IIIa ...reservoir description ... geologic: May 5, 1977, Conservation Hearing 非 45 exhibit \#1 8, State of Alaska $0 i l$ and Gas conservation Commission, 9 p.

McIntosh, W.L., and Eister, M.F., 1978, Geologic map index of Alaska: U.S. Geological Survey, 14 sheets,

McIvor, D.K., and Gryc, George, 1975, $0 i 1$ and gas developments in Arctic North America: World Petroleum Congress Proceedings, v. 3, no. 9 (exploration and transportation) p. 167-179.

McManus, D.A., and Creager, J.S., 1975, Bottom sediment data from the continental shelf of the Chukchi and Bering Seas, 1959-1963: Seattle, Univ. Wash., Department of Oceanography, Technical Report 135, Ref. M65-61 and M65-62, 2 vols.

Meckel, J.P., 1976, Environmental data collection along proposed Canadian gas pipeline along coastal route in Alaska, in Cobb, E.H., ed., The United States Geological Survey in Alaska; Accomplishments during 1975: U.S. Geological Survey Circular 733, p. 23. 


\section{REFEKENCES}

Mertz, R.W., Brooks, L.D., and Lansley, K.M., 1979, Deepwater vibrator operations, Beaufort Sea, 1979 winter season [abs.]: Society Exploration Geophysics, Annual International Meeting, Abstracts, no. 49, p. 30.

Metz, P.A., 1979, Carboniferous metallogeny of in the northern Brooks Range, Alaska: Alaska Science Conference, 30th, Fairbanks, 1979, Proceedings, p. 38-39.

Meyers, H., 1977, Seismicity of the Beaufort Sea, Bering Sea and Gulf of Alaska, in Annual reports of the principal investigators: v. 17, Hazards, OCSEAP, NOAA/BLM, p. 627-629.

Miller, B.M., Thomsen, H.L., Dolton, G.L., and others, 1975, Geological estinates of undiscovered recoverable oil and gas resources in the United States: U.S. Geological Survey Circular 725, 78 p.

Miller, D.L., and Bruggers, D.E., 1980, Soil and permafrost conditions in the Alaskan Beaufort Sea, in Annual offshore Technology Conference, T'welfth, Houston, Texas, May 5-8, 1980, Proceedings, v. 3, p. 25-38.

Moening-Grey Associates, 1976, Soil investigation, proposed generator building, Barrow, Alaska: Anchorage, Moening-Grey, unpublished report.

, undated, Soils-foundation investigation for proposed Barrow career high school site, Barrow, Alaska: Anchorage, Moening-Grey, unpublished report.

Mollard, J.D., 1978, Methods of presenting geological information, pipeline route selection [abs.]: GSA Abstracts with Prograns, v. 10, no 7, p. 458. (Presented at The Geological Association of Canada/ The Mineralogical Association of Canada/ The GSA 91st Annual Meeting; 1978 Joint annual meeting.)

Molnia, B.F., 1979, Sand and gravel resources of the continental shelf of Alaska: Avaliable from U.S. Geological Survey, Menlo Park, California, $69 \mathrm{p}$.

Moore, B.J., 1976, Analyses of natural gases, 1975: U.S. Bureau of Mines, Information Circular $8717,82 \mathrm{p}$.

Morgan, A.V., Morgan, Anne, and Carter, L.D., 1979, Paleoenvironmental interpretation of a fossil insect fauna from bluffs along the lower Colville River, Alaska, in Johnson, K.M., and Williams, J.R., eds., The United States Geological Survey in Alaska; Accomplishments during 1978: U.S. Geological Survey Circular 804-B, p. 41-44

Moritz, R. 1977, On a possible sea-breeze circulation near Barrow, Alaska: Arctic and alpine research, v. 9, p. 427-431.

, 1979, Synoptic climatology of the Beaufort Sea coast of Alaska: Boulder, Univ. Colorado, Institute of Arctic and Alpine Research, Occasional Paper $30,176 \mathrm{p}$. 


\section{REFERENCES}

Mountain, D.G., 1974, Preliminary analysis of Beaufort Sea circulation in sumer; in Coast and Shelf of the Beaufort Sea: Arlington, Virginia, Arctic Institute of North America, p. 27-42.

Mowatt, T.C., and Naidu, A.S., 1974, Gravels fron the Alaska continental shelf, Beaufort Sea, Arctic Ocean: Petrologic character and implictations for sediment source and transport: Alaska Division of Geological and Geophysical Surveys Open-tile Report AOF-43, 70 p.

Mowatt, T.C., Naidu, A.S., and Veach, Namok, 1974, Clay mineralogy of the lower Colville River and Colville Delta, north Arctic Alaska: Alaska Division of Geological and Geophysical Surveys Open-file Report AOF-45, 39 p.

Muggeridge, D.B., ed., and Peters, G.R., Chm., 1977, International conference on Port and Ocean engineering under Arctic conditions, Fourth, St. Johns, Newfoundland, Canada, Menorial Univ. Newfoundland, Sept 26-30, 1977, Proceedings, 2 vols.

Mu11, C.G., 1979, Nanushuk Group deposition and the late Mesozoic structural evolution of the central and western Brooks Range and Arctic Slope, in Ahlbrandt, T.S., ed., Preliminary geologic, petrologic, and paleontologic results of the study of Nanushuk Group rocks, North Slope, Alaska: U.S. Geological Survey Circular 794, p. 5-13.

Mu11, C.G., and Kososki, B.A., 1977, Hydrocarbon assessment of the Arctic National Wildlife Range, eastern Arctic Slope, Alaska, in Blean, K.M., ed., The United States Geological Survey in Alas'ka; Accomplishments during 1976: U.S. Geological Survey Circular 751-B, p. B20-B22.

, undated, Hydrocarbon potential of the Arctic National Wildlilfe Range, Alaska: U.S. Geological Survey administrative report transmitted to U.S. Fish and Wildlife Service, Division of Wildlife Refuges, on August $31,1976,26$ p.

Mu11, C.G., and Roeder, D., 1978, Tectonics of Brooks Range ophiolites, Alaska: AAPG Bulletin, v. 62, no. 9, p. 1696-1702.

Mu11, C.G., and Tailleur, I.L., 1977, Sadlerochit Group in the Schwatka Mountains, south-central Brooks Range, in Blean, K.M., ed., The United States Geological Survey in Alaska; Accomplishments during 1976: U.S. Geological Survey Circular 751-B, p. B27-B29.

Mu11, C.G., Tailleur, I.L., Mayfield, C.F., and Pessel, G.H., 1976, New structural and stratigraphic interpretations, central and western Brooks Range and Arctic Slope, in Cobb, E.H., ed., The United States Geological Survey in Alaska; Accomplishments during 1975: U.S. Geological Survey Circular 733 , p. 24-26.

Mulligan, J.J., 1974, Mineral resources of the Trans-Alaska pipeline corridor: U.S. Bureau of Mines Information Circular, no. 8626, 24 p, map scale $1: 190,080$. 


\section{REFERENCES}

Mungall, J.C.H., and others, 1978, Oceanographic processes in a Beaufort Sea barrier island-lagoon system; Numerical modelling and current measurenents: Annual report of the principal investigators, v. 10, Transport: OCSEAP, NOAA/BLM, p. 732-830.

Munga11, J.C.H., Whitaker, R.E., and Pace, S.D., 1979, Oceanographic processes in a Beaufort Sea barrier island-lagoon system; Numerical modelling and current measurements: Annual reports of the principal investigators, Environmental assessment of the Alaskan Continental Shelf, NOAA/BLM.

Naidu, A.S., 1978, Sediment characteristics, stability and origin of the barrier island-lagoon complex, north arctic Alaska; in Annual reports of the principal investigators for the year ending March, 1978: v. 10, Transport: OSCEAP, NOAA, p. 628-686.

, 1979, Sources, transport pathways, depositional site and dynamics of sediments in the lagoon and shallow marine region, northern Arctic Alaska: Annual report of the principal investigators, OCSEAP, NOAA.

Naidu, A.S., Burre11, D.C., Hood, D.W., and Dygas, J.A., 1975, Texture, clay mineralogy and chemistry of bottom sediments, west Beaufort Sea, Arctic Ocean, in Forbes, R.B., ed., Contributions to the geology of the Bering Sea Basin and adjacent regions: GSA Special Paper 151, p. 49-58.

Naidu, A., and Mowatt, T.C., 1974a, Aspects of size distributions, mineralogy and geochemistry of deltaic and adjacent shallow marine sediments, north arctic Alaska; in Environmental studies of an arctic estuarine system-final report: Eairbanks, Univ. Alaska, Institute of Marine Science Report R74-I, p. $145-208$.

, 1974, Clay mineralogy and geochemistry of continental shelf sediments of the Beaufort Sea; in Reed, J.C., and Slater, J.E. eds., Coast and shelf of the Beaufort Sea: Arlington, Virginia, Arctic Institute of North America, p. 493-510.

, 1975, Depositional environments and sediment characteristics of the Colville and adjacent deltas, northern arctic Alaska; in Broussard M.L. ed., Deltas, models for exploration: Houston, Houston Geological Society, p. 283-309.

, 1976, Modern depositional framework of the deltaic complex in North Arctic Alaska: in Miller, T.P., ed., Recent and ancient sedimentary environments in Alaska: Anchorage, Alaska Geological Society, symposium, p. D1-D12.

Namtvedt, Thomas, Parrish, Scott, Friese, Nancy, 1974, The Alaskan arctic coast, A background study of available knowledge: Arlington, Virginia, Arctic Institute of North America, 551 p.

National Petroleum Reserve in Alaska Task Force, 1978a, Geology in Physical profile; Study report 1: NPRA $105(\mathrm{c})$, p. $19-48$

, 1978b, Mineral resources; Section 8, in Values and resource analysis: v. 2, NPRA $105(\mathrm{c}), \mathrm{p} .8-1$ to $8-58$. 


\section{REFERENCES}

National Petroleum Reserve in Alaska Task Force, 1978c, National Petroleum Reserve in Al.aska, physical profile: U.S. Department of the Interior, NPRA, 105(c) Land Use Study, Study Report 1, 124 p.

1978d, National Petroleum Reserve in Alaska, values and resource analysis, land resources: U.S. Department of the Interior, NPRA, 105 (c) Land Use Study, Study Report 2, Section 10, p. 10-1 to 10-37.

, 1978e, National Petroleum keserve in Alaska, values and resource analysis, mineral resources: U.S. Department of the Interior, NPRA, 105 (c) Land Use Study, Study Report 2, Scetion 8, p. 8-1 to 8-58.

, 1978f, National Petroleum Reserve in Alaska, values and resource analysis, watershed resources: U.S. Department of the Interior, NPRA, 105 (c) Land Use Study, Study Report 2, section 9, p. 9-1 to 9-19.

, 1979a, Mineral resources; in 105(c) Final study: v. 2, NPRA 105(c)

p. $74-78$.

, 1979b, Mineral resources in planning area analysis: Study report 6, NPRA 105(c) land use study, p. 84-96.

, 1979c, Mineral resources in 105(c) Final study: v. 1, NPRA p. 122-133.

National Petroleum Reserve in Alaska Work Group 5, 1979, National Petroleum Keserve in Alaska, Mineral resources: U.S. Dept. of the Interior, NPRA 105(c) Land lise Study, Field Report 5.

Nauman, J.W., and Kernodle, D.R., , 1975, The effect of a fuel oil spill on benthic invertebrates and water quality on the Alaska Arctic slope, Happy Valley Creek near Sagwon, Alaska: U.S. Geological Survey Journal of Research, v. 3, no. 4, p. 495-500.

, 1976, Water quality and benthic invertebrates along the TAPS route, in Cobb, E.H., ed., The United States Geological Survey in Alaska; Accomplishments during 1975: U.S. Geological Survey Circular 733, p. 8.

, 1977, Aquatic organisms from selected sites along the trans-Alaska pipeline corridor, Sepetmber 1970 to September 1972: U.S. Geological Survey Open-file Report 77-634, 55 p.

Nauman, J.W., Sloan, C.E., and Kernodle, D.R., 1977, Effects of fuel oil leaks on water quality in three streams along the trans-Alaska pipeline, in Blean, K.M., ed., The United States Geological Survey in Alaska; Accomplishments during 1976: U.S. Geological Survey Circular 751-B, p. B7.

Nelson, G.L., 1977, North slope water resources studies, in Blean, K.M., ed., The United States Geological Survey in Alaska; Accomplishments during 1976: U.S. Geological Survey Circular 751-B, p. B31.

Ne1son, Hans, and Creager, J.S., 1977, Displacement of Yukon-derived sediment from Bering Sea to Chukchi Sea during Holocene time: Geology, v. 5, no. 3, p. 141-146, v. 5, no. 4, p. 194, Geology v. 5, no. 4, inside front cover [correction]. 


\section{REFERENCES}

Nelson, S.W., Nokleberg, W.J., Miller-Hoare, Martha, and Mullen, M.W., 1979, Siniktanneyak Mountain ophiolite, in Johnson, K.M., and Williams, J.R., eds., The United States Geological Survey in Alaska: Accomplishments during 1978: U.S. Geological Survey Circular 804-B, p. B14-B16.

Nerneth, D.F., 1977, Morphology, grain size characteristics and fluvial processes of two bars, Colville River Delta, Alaska: Baton Rouge, Louisiana State Univ. Ph.D. thesis, $146 \mathrm{p}$.

Newman, G.E., Mu11, C.G., and Watkins, N.D., 1977, Northern Alaska paleomagnetism, plate rotation and tectonics; in The relationship of plate tectonics to Alaskan geology and resources: Alaska Geological Society Symposium, Anchorage, Apri1 4,5,6, 1977, Program and abstracts, p. 16-19.

Niedoroda, A., Chin, H., and Mangarella, P. 1979, Addendum to 1978 summer environmental studies associated with the Prudhoe Bay dock; physical oceanography and benthic ecology: Draft report to ARCO Oil and Gas Co,, by Woodward-C1yde, Associates, Anchorage, 23 p.

Nilsen, T.H., Brosge, W.P., Dutro, J.f., and Moore, T.E., 1980, The Kanayut conglomerate, a major Upper Devonian delta complex, Brooks Range, northern Alaska [abs.]: GSA, 93rd annual meeting, Atlanta, Ga., 1980, Abstracts with program, p. 492.

Nilsen, T.h., Moore, T.E., and Brosge, W.P., 1980, Paleocurrent maps for the Upper Devonian and Lower Mississippian Endicott Group, Brooks Range, Alaska: U.S. Geological Survey Open-file Report 80-1066, 2 sheets, scale $1: 1,000,000$.

Nilsen, T.H., Moore, T.E., Dutro, J.T., Jr., Brosge, W.P., and Orchard, D.M., 1980, Sedimentology and stratigraphy of the Kanayuk Conglomerate and associated units, central and eastern Brooks Range, Alaska; Report of the 1978 field season: U.S. Geological Survey Open-file Report 80-888, 40 p.

NOAA/BLM, 1978, Environmental assessment of the Alaskan continental shelf; Interim synthesis: Beaufort/Chukchi: Boulder, Colorado, National Oceanic and Atmospheric Administration, $362 \mathrm{p}$.

Nokleberg, W.J., and Winkler, G.R., 1978a, Geologic setting of the lead and zinc deposits, Drenchwater Creek area, Howard Pass, quadrangle, western Brooks Range, Alaska; U.S. Geological Survey Open-file Report 78-70C, 16 p.

, 1978b, Geologic setting of stratiform zinc-lead mineralization, Drenchwater Creek area, Howard Pass quadrangle, western Brooks Range, Alask [abs.]: GSA Abstracts with Programs, v. 10, no. 3, p. 139.

, 1978c, Stratiform zinc-lead mineralization, Drenchwater Creek area, Howard Pass quadrangle, western Brooks Range, Alaska, in Johnson, K.M., ed., The United States Geological Survey in Alaska; Accomplishments during 1977: U.S. Geological Survey Circular 772-B, p. B.17-B19. 


\section{REFERENCES}

Nokleberg, W.J., Plahuta, J.T., Lange, I.M., and others, 1979a, Volcanogenic zinc-lead mineralization in pelagic sedimentary rocks of late Paleozoic age, northwestern Brooks Range, Alaska [abs.]: Geological Association of Canada Abstracts with Programs, v. 4, p. 21.

, 1979b, Volcanogenic zinc-lead-barite deposits in pelagic rocks of late Paleozoic and early Mesozoic age, northwestern Brooks Range, Alaska [abs.]: GSA Abstracts with Programs, v. 11, no. 7, p. 487-488.

Norris, D.K., 1978, Geological maps of the Yukon Territory and Northwest Territories: Geological Survey of Canada Open-file Report OF-499, 6 sheets, $1: 250,000$.

Norris, D.K., 1980, Geology northern Yukon Territory and northwestern district of Mackenzie: Geological Survey of Canada Open-file Report 715, 1:500,000.

Norwegian Institute of Technology, University of Trondheim, 1979, Fifth international conference on port and ocean engineering under arctic conditions: Trondheim, Norway, Norwegian Institute of Technology, Aug. 13-18, 1979, Proceedings, 3 vols.

Numenda1, Dag, Fisher, I.A., and Knoth, J.S., 1978, 011 spill vulnerability of: the Beaufort Sea Coast: Annual report of the principal investigators, OCSEAP, NOAA.

Numendal, Dag, Knoth, J.S., Fischer, I.A., and Fahnestock, R.K., 1978, Transgressive barriers of Beaufort Sea coast [abs.]: AAPG Bulletin, v. 62, no. 3, p. 550 .

Oceanographic Institute of Washington, 1979, Alaska North Slope wetlands study: Part 2. Soil and hydrology: Prepared for U.S Army Corps of Engineers.

Oceanographic Services, Inc., 1976, Ice movement study for winter, 1975-1976, Beaufort Sea, Alaska: contracted by Amoco Production Company, Security Life B1dg, Denver, Colo.

, 1978a, Beaufort Sea ice movenent study 1976-1977: For Shell and others, coordinated by Amoco, Confidential thru June 1, 1982. Cost to next participant, $\$ 92,402$.

, 1978b, Summary analysis of 1975-1975 Beaufort Sea aerial photography: for Amoco and others, confidential until August 1, 1984, cost to next participant, $\$ 4,063$ plus participation in another project.

, 1979a, Beaufort Sea ice movement study: For Shell and others, Confidential thru June 1, 1983. Cost to next participant, $\$ 90,166$.

, 1979b, Beaufort Sea meteorological and oceanographic measurement program (BEAUMOP), for Gulf Research and Development Co., and others, P.o. Box 36506, Houston, Texas 77036, confidential, earliest of one year after the Beaufort Sea nearshore lease sale or five years after program termination, cost to next participant $\$ 53,600$. 


\section{REFERENCES}

Oceanographic Services, Inc., 1980a, Beaufort Sea ice movement study, 1978-79: For ARCO and others, confidential until October 1, 1984. Cost to next participant, $\$ 46,775$.

, 1980b, Beaufort Sea ice movement study, 1979-80: Cost to next participant, $\$ 70,000$.

, 1980c, Beaufort Sea Oceanographic freeze-up movement study - 1979: for ARCO and others. Confidential until September 1, 1985. Cost to next participant, $\$ 37,500$.

, 1980d, Beaufort Sea oceanographic measurement program, 1979: For ARCO, Exxon, She1l, confidential until April, 1990, Cost to next participant, $\$ 45,000$.

, 1980e, Beaufort Sea ice movement studies (BSIMS) Three-year summary and analysis: For Amoco and others, Confidential until October l, 1984. Cost to next participant approximately $\$ 33,676$ with some prerequisites.

Oceanweather, Inc. and Sea Ice Consultants, Inc., 1979, Beaufort Sea extreme and normal oceanographic conditions study: for Shell and Mobil, Confidential until April, 1989 , cost $\$ 20,000$ per participant.

Offshore, 1975a, New pool discovered off Prudhoe Bay: v. 35, no. 3, p. 103. , 1975b, Prudhoe Bay field will get 130 wells by 1977 and 1.2 million b/d: v. 35 , no. 4, p. 110-112. , 1975c, Gwydyr find enhances Prudhoe interest: v. 35, no. 5, p. 188.

, 1975d, Exxon wildcat may indicate a new field east of Prudhoe Bay: v. 35, no. $11, \mathrm{p} .71$.

, 1977a, Exxon sinks wildcat near suspended well in Prudhoe Bay: v. 38, no. 5, p. 276 .

, 1977 b, Navy oil tests score shallow results (NPR-4): v. 38, no. 5, p. 382.

, 1977c, As Prudhoe Bay production climbs, so does Alaska's status with industry: v. 37, no. 10, p. 124, 127.

, 1978a, Point Thomson; an up-and-coming area: v. 38, no. 4, p. 129-130.

, 1978b, Exxon reports third discovery offshore Alaska (Point Thomson area): v. 38 , no. 11, p. 231 .

Oil and Gas Journal, 1975a, Prudhoe Bay well tests 1,350 b/d from Lisburne formation: v. 73 , no. 3 , p. 40-41.

, 1975b, Arctic region holds 30 trillion cu ft (Prudhoe Bay and Mackenzie Delta): v. 73 , no. 5, p. 52 .

, 1975c, North Slope strike flows 2300 b/d: v. 73, no 15, p. 37. 


\section{REFERENCES}

Oil and Gas Journal, 1975d, Test on North Slope listed as dry hole: v. 73, no. $20, \mathrm{p} .57$.

, 1975e, Navy's North Slope test dry: v. 73, no. 22, p. 47.

, 1975f, Wildcatters poised for Beaufort Sea: v. 73, no. 22, p. 98.

, 1975g, Big plans on tap for two Alaskan wildcat areas: v. 73, no. 22,

p. $104-112$.

, 1975h, Explorers face big challenge off Alaska: v. 73, no. 27, p. 85-90.

, 1975i, New study pares Prudhoe oil reserves: v. 73, no. 51, p. 34.

, 1976a, Geologist calls Prudhoe one of a kind: v. 74, no. 44, p. 32 .

, 1976b, Dozen North Slope exploratory holes slated: v. 74, no 51, p. 32-33.

, 1977a, Resid HDS can cope with Alaskan North Slope crude oil: v. 75 , no. 6 , p. $66-70$.

, 1977b, Navy gets North Slope gas find and dry hole (South Barrow field)

v. 75, no. 9, p. 51 .

, 1977c, Petroleum potential of the Lisburne Group, eastern Arctic Slope,

Alaska: v. 75, no. 16, p. 90-94.

, 1977d, Interior to take over NPR June 1: v. 75, no. 22, p. 59.

, 1977e, Both onshore and offshore Alaska hold vast exploration potential:

v. 75, no. 26, p. 198-202.

, 1977f, Exxon may have oil discovery on the North Slope ( 1 pt. Thomson Unit): v. 75 , no. $38, \mathrm{p} .59$.

, 1977g, Kuparuk development eyed on North Slope: v. 75, no. 41 p. 53-54.

, 1977h, Exxon scores again on North Slope: v. 75, no. 46, p. 30.

, 1977i, New field may be shaping up east of Prudhoe: v. 75, no. 47, p. 104-105.

, 1977j, Pet-4 drilling activity to revive in 1978: v. 75, no. 49, p. 91.

, 1978, Tests indicate limited reservoir at slope well: v. 76, no. 23, p. 39.

, 1979a, How operators view Prudhoe Bay now: v. 77, no. 9, p. 67-72.

, 1979b, Alaska explorers still sure big finds coming: v. 77 no.9, p. $72-77$.

, 1979c, ARCO to develop Kuparuk west of Prudhoe Bay: v. 77, no. 14, p. 60 . 


\section{REFERENCES}

Oil and Gas Journal, 1979d, Alaskan NPR claims two more wildcat failures: v. 77, no. 17, p. 42 .

, 1979e, National Arctic Wildlife Range seen best potential for huge discovery: v.77, no. 32, p. 149-150, 155.

, 1979f, List of dry holes lengthens on Alaskan slope: v. 77, no. 33, p. 50. , 1979g, Mackenzie, Beaufort exploration halt urged: v. 77, no. 35, p. 52. , 1979h, Open waters of Beaufort host major oil strike: v. 77, no. 38 , p. 42 .

, 1979i, More exploration seen in area mulled for Bering Strait 1ine: v. 77 , no. 42, p. 102 .

, 1980a, Prudhoe 1980 output to average current MER; 1.5 million b/d: v.78, no. 1, p. 56.

, 1980b, Industry eyes big new search area in Alaska (NPR-A): v. 78, no. 12, p. $43-46$.

, 1980c, Source water injection seen hiking Prudhoe output: v. 78, no. 15, p. 60 .

, 1980d, North Slope 0il; a bargain for lower 48 refiners: v. 78, no. 16, p. $27-30$.

, 1980e, Alaska slates June sale of North Slope tracts: v. 78, no. 17 , p. 60 .

, 1980f, First oil recovered from Arctic wildcat: v. 78, no 18, p. 121.

, 1980g, Constraints of geologic processes on western Beaufort Sea oil

developments: v. 78, no. 18, p. 304-319.

, 1980h, Slope entitlements changes proposed: v. 78, no. 20, p. 50 .

, 1980i, Interior to issue Beaufort Sea leases: v. 78, no. 29, p. 29.

, 1980j, Andrus; Range in Alaska is no target: v. 78, no. 29, p. 34.

, 1980k, Interior cuts oil, gas estimates in Alaskan NPR: v. 78, no. 30, p. 138.

-, 19801, North Slope gets environmental okay: v. 78, no. 31, p. 22.

, 1980m, House bill contains NPRA leasing requirement: v. 78, no. 32, p. 50 .

, 1980n, U.S.G.S intensifying research efforts in Alaska: v. 78, no. 34, p. 52 .

, 19800, U.S. Beaufort test, second Alaska Gulf sale set: v. 78, no. 37 , p. 108-109. 


\section{REFERENCES}

Oil and Gas Journal, 1980p, Sohio spuds Alaskan Beaufort Sea wel1: v. 78, no $46, \mathrm{p} .36$. , 1980q, U.S. wells completions for September, 1980: v. 78, no 45, p. 278.

Oliver, W.A., Jr., Merriam, C.W., and Churkin, Michael, Jr., 1975, Ordovician, Silurian, and Devonian corals of Alaska: U.S. Geological Survey Professional Paper 823-B, p. 13-44.

Olsen, E.W., Carlson, P.W., and Molnia, B.F., 1980, Characteristics of outer continental shelf lease areas in Alaska; in International Conference on Port and Ocean Engineering under Arctic Conditions, Fifth, Trondheim, Norway, v. 3, p. 963-976.

Osterkamp, T.E., and Harrison, W.D., 1976a, offshore permafrost-dril1ing, boundary conditions, properties, processes and models, v. 13, Geology: OCSEAP, NOAA, p. 138-256.

, 1976b, Subsea permafrost at Prudhoe Bay, Alaska: Drilling report and data analysis, Fairbanks, Univ. Alaska Geophysical Institute Report UAG-R-245.

Osterkamp, T.E., and Harrison, W.D., 1978b, Subsea permafrost probing, thermal regime and data analysis: Quarterly report, October-December, 1978, to OCSEAP, NOAA/BLM.

Ott, A.G., 1977, Gravel removal study sites in Arctic and subarctic streams in Alaska [abs.]; in Hickock, D.M., Chm., Science information exchange in Alaska: Alaska Science Conference Proceedings, no. 28, v. 4, p. 36-318.

Overstreet, W.C., Crenshaw, G.L., Hubert, A.E., Rosemblum, Sam, and Smith, R.J., 1975, Experimental results of atomic absorption analyses for indium and thallium in 803 nonmagnetic concentrates from Alaska: U.S. Geological Survey Open-file Report 75-253, 78 p.

Overstreet, W.C., Hamilton, J.C., Boerngen, J.G., Rosenblum, Sam, Marsh, W.R. , and Sainsbury, C.L., 1975, Minor elements in nonmagnetic concentrates from Alaska: National Technical Information Service PB-238 989/AS, 440 p.

Owens, E.H., 1977, Variations in coastal environments and beach morphology of northern Alaska [abs.]: AAPG Bulletin, v. 61, no. 5, p. 818-819.

Page, F.W., and Iskandar, I.K., 1978, Geochemistry of subsea permafrost at Prudhoe Bay, Alaska: U.S. Army CRREL Special Report 78-14.

Palmer, I.F., Jr., Bolm, J.G., Maxey, L.R., and Lyle, W.M., 1979, Petroleum source rock and reservoir quality data from outcrop samples, onshore North Slope of Alaska east of Prudhoe Bay: U.S. Geological Survey Openfile Report 79-1634, 52 p., 14 pl.

Parkinson, R.J., 1978, Genesis and classification of Arctic Coastal Plain soils, Prudhoe Bay, Alaska: Ohio State University, Institute of Polar Studies Report 68, 147 p. 


\section{REFERENCES}

Parsons, Barry, and Sclater, J.G., 1977, An analysis of the variation of ocean floor bathymetry and heat flow with age: Journal of Geophysical Research, v. 82, p. $803-827$.

Patterson, S.O., and Harris, J.R., 1978, Sumary of recent exploration and evaluation work on NPRA [abs.]: AAPG Bul1., v. 62, no. 11, p. 2359.

Patton, W.W., Jr., and Tailleur, I.L., 1977, Evidence in the Bering Strait region for differential movement between North America and Eurasia: GSA Bulletin, v. 88, no. 9, p. 1298-1304.

Patton, W.W., Jr., Tailleur, I.L., Brosge, W.P., and Lanphere, M.A., 1977, Preliminary report on the ophiolites of northern and western Alaska; in Coleman, K.G., and Irwin, W.P., eds., North American ophiolites: Oregon Dept. Geology and Mineral Industries, Bulletin, 95, p. 51-57.

PBUWTF, 1979, Prudhoe Bay unit waterflood project overview: v. I, engineering, Dec. 1979, update. Prepared by Prudhoe Bay unit waterflood Task Force.

Pelletier, B., 1974, Discussion of papers on geological action of sea ice, sedimentation, and sea floor morphology; in Reed, J.C., and Slater, J.E., eds, The coast and shelf of the Beaufort Sea: Arlington, Va., Arctic Institute of North America, p. 541-542.

Pessel, G.H., Levorsen, J.A., and Tailleur, I.L., 1978a, Generalized structure map of the Lower Cretaceous unconformity, eastern North Slope petroleum province, Alaska: U.S. Geological Survey Miscellaneous Field Studies Map MF-928H, 1 sheet, scale 1:500,000.

Pessel, G.H., Levorsen, J.A., and Tailleur, I.L., 1978a, Generalized isopach and net sand maps of Lower Cretaceous sands, eastern North Slope petroleum province, Alaska: U.S. Geological Survey Miscellaneous Field Studies Map MF-928J, 1 sheet, scale 1:500,000.

, 1978c, Generalized isopach map of (Jurassic) and possibly Lower Cretaceous shale, including Kingak Shale, eastern North Slope petroleum province, Alaska: U.S. Geological Survey Miscellaneous Field Studies Map MF-928K, 1 sheet, scale 1:500,000.

, 1978d, Generalized isopach map of Sag River Sandstone and overlying siltstone, eastern North Slope petroleum province, Alaska: U.S. Geological Survey Miscellaneous Field Studies Map MF-928M, 1 sheet, scale 1:500,000.

, 1978e, Generalized isopach map of the Shublik Formation, eastern North Slope petroleum province, Alaska: U.S. Geological Survey Miscellaneous Field Studies Map MF-928N, 1 sheet, scale 1:500,000.

Pesse1, G.H., and Tailleur, I.L., 1978, Generalized isopach map of the Echooka Formation, eastern North Slope petroleum province, Alaska: U.S. Geological Survey Miscellaneous Field Studies Map, MF-928R, 1 sheet, scale 1:500,000. 


\section{REFERENCES}

Pessel, G.H., Tailleur, I.L., and Bird, K.J., 1978a, Generalized structure map of the top of the Colville Group, eastern North Slope petroleum province, Alaska: U.S. Geological Survey Miscellaneous Field Studies Map MF-928C, 1 sheet, scale 1:500,000.

, 1978b, Generalized isopach map of sandstone within the Colville Group, eastern North Slope petroleun province, Alaska: U.S. Geological Survey

Miscellaneous Field Studies Map MF-928D, 1 sheet, scale 1:500,000.

, 1978c, Generalized isopach map of shale in the Colville Group, eastern North Slope petroleum province, Alaska: U.S. Geological Survey Miscellaneous Field Studies Map MF-928E, 1 sheet, scale 1:500,000.

, 1978d, Generalized isopach map of Colville Group, eastern North Slope petroleum province, Alaska: U.S. Geological Survey Miscellaneous Field Studies Map MF-928F, 1 sheet, scale 1:500,000.

Pessel, G.H., Tailleur, I.L., and Levorsen, J.A., 1978, Generalized structure map of top of Sag River Sandstone, eastern North Slope petroleum province, Alaska: U.S. Geological Survey Miscellaneous Field Studies Map MF-928L, 1. sheet, scale 1:500,000

Peterson, L.A., 1979, Prudhoe Bay waterflood project; Elutriat, shallow sediment and water quality data: Prepared for Dames and Moore, Anchorage.

Peterson, L.A., 1979, Systhesis of water and material resources information on Alaska's North Slope between the Colville and Canning Rivers: Prepared for the State of Alaska, Department of Natural Resources, Division of Forest, Land and Water Management.

Petroleum Engineer, 1974, North Slope readies for action: v. 46, no.1, p. 48-56. , 1980, Arco tackles North Slope again - at Kuparuk field: v. 52, no. 1, p. $26-32$.

Petroleum Information, 1978, Alaska Report: v. 24, no. 8, sec 2., p. 2, Sept. $20,1978$.

Pewe, T.L., 1975, Quaternary geology of Alaska : U.S. Geological Survey Professional Paper 835, $145 \mathrm{p}$.

Plahuta, J.T., 1978, Geologic map and cross sections of the Red Dog prospect, DeLong Mountains, northwestern Alaska: U.S. Bureau of Mines Open-file Report 65-78, 11 p.

Plahuta, J.T., Lange, I.M., and Jansons, Uldis, 1978, The nature of mineralization at the Red Dog Prospect, Western Brooks Range, Alaska: Paper presented at the $74 \mathrm{th}$ annual meeting of the Cordilleran Section of the GSA, Tempe, Arizona. March 29, 1978, (a1so as GSA Abstracts with Programs, v. 10 , no. 3 , p. 142.)

Platt, J.B., 1975, Petrography of University of Washington dredge samples from the central Chukchi Sea: U.S. Geological Survey Open-file Report 75-269, $25 \mathrm{p}$. 


\section{REFERENCES}

Porterfield, Bob., 1974, Pet. 4; Alaska's next bonanza?: Alaska Construction and Oil, December, 1974, p. 10-20.

Post, Austin and Meier, M.F., 1979, Glacier inventories, in Johnson, K.M., and Williams, J.R., eds., The United States Geological Survey in Alaska; Accomplishments during 1978: U.S. Geological Survey Circular 804-B, p. B7.

Powe11, T.G., Cook, P.J., and McCurdy, D.M., 1975, Organic geochemistry of phosphorties; revelance to petroleum genesis: AAPG Bulletin, v. 59, no.4, p. $618-632$.

Pratt, R.M., Andrews, J.K., and Simonson, R.R., 1977, Preliminary summary NPR-4 FY 177 drilling program: for Husky 011 NPR Operations, Inc. under contract to U.S. Geological Survey by Tetra Tech, Houston, Texas.

Puchtler, Bertold, Reid, Barry, and Christianson, Conrad, 1976, Water related utilities for small communities in rural Alaska, EPA-600/3-76-104: Ecological Research Series, U.S. Environmental. Protection agency.

Reed, J.C., and Slater, J.E., eds., 1974, The coast and shelf of the Beaufort Sea: Arlington, Virginia, Arctic Institute of North America, 750 p.

Reger, Richard D., 1976, North Slope water and grave1 resource investigations: State of Alaska Memoranaum to Ross G. Schaff, Director, Alaska Division of Geological and Geophysical Surveys.

Reimnitz, Erk, 1976, High resolution seismic profiles, Beaufort Sea: U.S. Geological Survey Open-file Report 76-747, 3 sheets, microfilm.

Reimnitz, Erk, and Barnes, P.W., 1974, Sea ice as a geologic agent on the Beaufort Sea shelf of Alaska; in Reed, J.C., and Slater, J.E., eds., The coast and shelf of the Beaufort Sea: Arlington, Va., Arctic Institute of North America, p. 301-353.

Reimnitz, Erk, Barnes, P.W., and Kempema, Edward, 1979, Marine geologic studies in the Beaufort Sea, Alaska, 1978; data type, 1ocation, records obtained, and their availability: U.S. Geological Survey Open-file Report 79-384, 4 p., 5 pl.

Reimnitz, Erk, Barnes, P.W., and Maurer, Douglas, 1979, USGS marine geologic studies in the Beaufort Sea, Alaska, 1976; data type, location, and records obtained: U.S. Geological Survey Open-file Report 79-766, 4 p.

Reimnitz, Erk, Barnes, P.W., and Melchoir, J., 1977, Changes in barrier island morphology - 1949 to 1975, Cross Island, Beaufort Sea, Alaska: U.S. Geological Survey Open-file Report 77-477, p. F1-F13.

Reimnitz, Erk, Barnes, P.W., and Toimil, L.J., 1977, A word of caution on the age of deep water ice gouges in the Beaufort Sea, in Barnes, P.W., Reimnitz, Erk, and Drake, D., 1977, Geologic processes and hazards of the Beaufort Sea shelf and coastal regions, Quarterly report of principal investigators, April-June, 1977: OCSEAP, NOAA/BLM. 


\section{REFERENCES}

Reimnitz, Erk, Barnes, P.W., Toimil, L.J., and Harden, D., 1976, Studies of the inner shelf and coastal sedimentation environment of the Beaufort Sea from ERTS - A Final report to NASA, National Technical Information Service Document 7710043, 105 p.

Reimnitz, Erk, Barnes, P.W., Toimil, L.J., and Melchoir, John, 1977, Ice Gouge recurrence and rates of sediment reworking, Beaufort Sea, Alaska: Geology, v. 5, no. 7, p. 405-408.

Reimnitz, Erk, and Dunton, K., 1979, Diving observations on the soft ice layer under the fast ice at DS-11 in the Stefansson Sound boulder patch; in Barnes, P.W., and Reimnitz, Erk, eds., Geologic processes and hazards of the Beaufort Sea shelf and coastal regions: Annual report of principal investigators, OCSEAP/NOAA, $17 \mathrm{p}$.

Reimnitz, Erk, Dunton, K., and Barnes, P.W., 1979, Anchor ice and lack of delta accretion in the Arctic; A possible link [abs.]: GSA Abstracts with Programs, v. 11, no.7, p. 501.

Reimnitz, Erk, Kempema, Edward, Ross, Robin, and Minkler, Peter, 1980, Overconsolidated surficial deposits on the Beaufort Sea shelf: U.S. Geological Survey Open-file Report 80-2010. 37 p.

Reimnitz, Erk, and Maurer, D.K., 1979a, Effects of storm surges on the Beaufort Sea coast, northern Alaska: Arctic, v. 32, no. 4 p. 329-344.

, 1979b, Eolian sand deflation: A cause for gravel barrier islands in Arctic Alaska?: Geology, v. 7, no. 10, p. 507-510.

Reinmitz, Erk, and Maurer, D.K., 1978a, Storm surges in the Alaskan Beaufort Sea: U.S. Geological Survey Open-file Report 78-593, 26 p. , 1978b, Stamukhi shoals of the Arctic - Some observations from the Beaufort Sea: U.S. Geological Survey Open-file Report 78-666, 17 p.

Reimnitz, Erk, Maurer, D.K., Barnes, P.W., and Toimil, L.J., 1977, Some physical properties of shelf surface sediments, Beaufort Sea, Alaska: U.S. Geological Survey Open-file Report 77-416, 23 p.

Reimnitz, Erk, Rodeick, C.A., and Wolf, S.C., 1974, Strudel scour: A unique arctic marine geologic phenomenon: Journal of Sedimentary Petrology, v. 44, no. 2, p. 409-420.

Reimnitz, Erk, and Ross, Robin, 1979, Lag deposits of boulders in Stefansson Sound, Beaufort Sea, Alaska: U.S. Geological Survey Open-file Report $79-1205,26 \mathrm{p}$.

Reimnitz, Erk, Ross, Robin, and Barnes, P.W., 1980, Dinkum Sands: U.S. Geological Survey Open-file Report 80-360, 11 p. 


\section{REFERENCES}

Reimnitz, Erk, and Toimil, L.J., 1977, Diving notes from three Beaufort Sea sites, in Barnes, P.W., and others, eds., Marine environmental problems in the ice covered Beaufort Sea shelf and coastal regime: Report of the principal investigators for the year ending March, 1977, OCSEAP/ NOAA, v. $17, \mathrm{p} . \mathrm{J} 1-\mathrm{J} 7$.

Reimnitz, Erk, Toimil, L.J., and Barnes, P.W., 1978, Arctic continental shelf morphology related to sea-ice zonation, Beaufort Sea, Alaska: Marine Geology v. 28, no. 3-4, p. 179-210.

, 1977, Stamukhi zone processes; implications for developing the Arctic offshore: Offshore Technology Conference Paper no. 19, v. 3, p. 513-518.

Reiser, H.N., Brosge, W.P., Detterman, R.L., and Dutro, J.T., Jr., 1978, Geologic map of the Demarcation Point quadrangle, Alaska: U.S. Geological Survey Open-file Report 78-526, 1 sheet, scale 1:250,000.

Reiser, H.N., Brosge, W.P., DeYoung, J.H., Jr., Marsh, S.P., Hamilton, T.D., Cady, J.W., and Albert, N.R.D., 1979, The Alaskan mineral resource assessment program: Guide to information contained in the folio of geologic and mineral resource maps of the Chandalar quadrangle, Alaska: U.S. Geological Survey Circular 758, 23 p.

Reiser, H.N., Brosge, W.P., Dutro, J.T, Jr., and Detterman, R.L., 1979, Upper Paleozoic volcanic rocks in the eastern and central Brooks Range, in Johnson, K.M., and Williams, J.R., eds., The United States Geological Survey in Alaska; Accomplishments during 1978: U.S. Geological Survey Circular 804-B, p. B25-B27.

Reiser, H.N., Norris, D.K., Dutro, J.T., Jr., and Brosge, W.P., 1978, Restriction and renaming of the Neruokpuk Formation, northeastern Alaska, in Sohl, N.F., and Wright, W.B., Changes in stratigraphic nomenclature by the U.S. Geological Survey, 1977: U.S. Geological Survey Bulletin, etin 1457-A, p. A106-A107.

Repenning, C.A., 1978, Fossil reconnaissance study, eastern NPRA, in Johnson, K.M., ed., The United States Geological Survey in Alaska; Accomplishments during 1977: U.S. Geological Survey Circular 772-B, p. B27.

Rieger, Samuel, Soephoerster, Dale, and Furbush, C.E., 1978, Exploratory soil survey of Alaska: U.S. Department of Agriculture, Soil Conservation Service, $213 \mathrm{p}$.

Ritchie, W., and Walker, H.V., 1974, Riverbank forms of the Colville River delta; in Reed, J.C., and Slater, J.E., eds., The coast and shelf of the Beaufort Sea: Arlington, Va., Arctic Institute of North America, p. 545-562.

Roeder, Deitrich, and Mull, C.G., 1978, Tectonics of Brooks Range ophiolites, Alaska: AAPG Bulletin, v. 62, no. 9, p. 1696-1702.

Roedick, C.A., 1974, Marine gravel deposits of the Beaufort Sea shelf [abs.] in Reed, J.C., and Slater, J.E., eds., The coast and shelf of the Beaufort Sea: Arlington Va., Arctic Institute of North America, p. 511. 


\section{REFERENCES}

Roedick, C.A., 1979, The origin, distribution and depositional history of gravel deposits on the Beaufort Sea continental shelf, Alaska: U.S. Geological Survey open-file Report 79-234, 87 p.

Roehler, H.W., and Stickler, G.D., 1979, Stratigraphy and sedimentation of the Torok, Kukpowruk and Corwin Formations of Cretaceous age in the KokolikUtukok River region, National Petroleum Reserve in Alaska: U.S. Geological Survey Open-file Report 79-995, 80 p., 2 pl.

Rogers, J.C., 1976, Beaufort Sea coast permafrost studies; in Annual reports of the principal investigators for the year ending March, 1976: OCSEAP, NOAA, v. 13, Geology, p. 257-284.

, 1977a, A meteorological basis for long-range forecasting of summer and early autumn sea ice conditions in the Beaufort Sea, in International Conference on Port and Ocean Engineeering under Arctic Conditions, Fourth, St. John's Newfoundland, Proceedings: v. 2, p. 952-962.

, 1978, Meteorological factors affecting interannual variability of summertime ice extent in the Beaufort Sea: Monthly Weather Review, v. 106 , p. 890-897.

, 1977b, Seismic investigation of offshore premafrost near Prudhoe Bay, Alaska, in Scott, W.J., ed., Proceedings of a symposium on permafrost geophysics: National Research Council, Canada, Association Comm. Geotechnical Research Tech Memo, no. 119, p. 71-77.

Rogers, J.C., Harrison, W.D., and Shapiro. L.H., and others, 1975, Nearshore permafrost studies in the vicinity of Point Barrow, Alaska: Fairbanks, Univ. Alaska, Geophysical Institute Report no. 237, 30 p. (Sea Grant Report 75-6.)

Rogers, J.C., and Morack, J.L., 1978, Beaufort Sea coast permafrost studies; in Reports of the principal investigators for the year ending March, 1978: v. 9 Hazards, OCSEAP, NOAA, p. 651-658, (also in 1980 Report of the principal investigators, v. 5, Hazards: OCSEAP, NOAA/BLM, p. 1-44.)

, 1980, Geophysical evidence of shallow nearshore permafrost, Prudhoe Bay, Alaska: Journal of Geophysical Research, v. 85, no. B9, p. 4845-4853.

, 1978, Geophysical investigation of offshore permafrost at Prudhoe Bay, Alaska, in International Conference on Permafrost, Third, Edmonton, Alberta, Proceedings, v. 1, no. 3, p. 560-566.

, 1976, Subsea permafrost investigations in the Beaufort Sea [abs.]; in West, G.C., ed., Science in Alaska, 1976: Alaska Science Conference Proceedings, v. 1 , no. 27, p. 174.

Rowett, C.L., 1975, Stratigraphic distribution of Permian corals in Alaska: U.S. Geological Survey Professional Paper 823-D, p. 59-75. 


\section{REFERENCES}

Roy, K.J., Procter, K.N., and McCrossan, R.G., 1975, Hiydrocarbon assessment using subjective probability, in Davis, J.C., and others, conveners, Probability methods in oil exploration: AAPG Research Symposium, Menlo Park, California, Stanford University Notes, p. 56-60.

Ruppe1, B.D., and McHendrie, Graig, 1975, Free air gravity anomaly profiles from the Chukchi Sea: U.S. Geological Survey Open-file Report 75-343, 2 maps, 9 profiles.

, 1976, Free-air gravity anomaly map of the eastern Chukchi and southern Bering Seas: U.S. Geological Survey Miscellaneous Field Studies Map MF-785, 1 sheet, scale 1:2,000,000.

Sable, E.G., 1977, Geology of the western Romanzof Mountains, Brooks Range, Alaska: U.S. Geological Survey Professional Paper 897, 84 p.

Sainsbury, C.L., and Bloomstein, Edward, 1977, Compressive interaction of Siberian and North American plates, Bering Strait region, Alaska [abs.]: American Association of Petroleum Geologists Bulletin, v. 61, no. 3, p. 467.

Sando, W.J., 1974, Checklist of North American late Paleozoic coral species (Coelenterata, Anthozoa): U.S. Geological Survey Bulletin, 1387, 36 p.

Schallock, E.W., 1975, Inplications of resource development on the North Slope of Alaska with regard to water quality on the Sagavanirktok River: Symposium-Freshwater Quality Criteria Research, U.S. Environmental Protection Agency, Corvallis, Oregon, 1975.

Schinlder, J. and Walker, H.J., 1975, Nearshore environments of the North Slope and the petroleum industry: Geoscience: Man, v. 12, p. 67-75.

Schmidt, R.A.M., and Champion, C.A., 1976, Environmental and geologic concerns in construction of the Trans-Alaska Pipeline [abs.]: International Geology Congress Abstracts - Congress of Geology International, Resumes, 25, v. 2 (Sect. 13, engineering geology), p. 543.

Schoennagel, F.H., 1977, Mississippian unconformities in northern Alaska related to Antler tectonic pulses: AAPG Bulletin, v. 61, no. 3, p. 435-442.

Scott, W.R., 1979, Alaskan Beaufort Sea gravity survey [abs.]: Society of Exploration Geophysicists, Annual. International Meeting, Abstracts, 49, p. 63.

Schumacher, G.M., 1976, Bathymetric maps of Chukchi Sea and Arctic Ocean: U.S. Geological. Survey Open-file Report 76-823, 2 sheets, scale 1:2,500,000.

Scott, K.M., 1979, Arctic stream processes - An annotated bibliography: U.S. Geological Survey Water-Supply Paper 2065, 78 p.

, 1978, Effects of permafrost on stream channel behavior in arctic Alaska: U.S. Geological Survey Professional Paper 1068, 19 p. 


\section{REFEREINCES}

Scott, R.A., and Smiley, C.J., 1979, Some Cretaceous plant megafossils and microfossils from the Nanushuk Group, Northern Alaska, a preliminary report, in Ahlbrandt, T.S., ed., Preliminary geologic, petrologic, and paleontologic results of the study of Nanushuk Group rocks, North Slope, Alaska: U.S. Geological Survey Circular 794, p. 89-111.

Sea Ice Consultants, 1979, Sea ice conditions along the North Slope of Alaska, Cape Halkett to Flaxman Island, June thru October, 1976, 1977, 1978: For Shell Development Co., Bellaire Research Center license information: Patents and licensing Div., Shell Development Co., Box 2463, Houston, Texas, 77701, Cost: fixed license fee to Shel1 $\$ 5,000$, copy cost for reproduction to Sea Ice consultants: no more than $\$ 150$ per copy.

, 1976, Summer sea ice conditions, North Alaskan coast: Amoco Production Co. (Research department) and others, P.0. Box 591, Tulsa, Okla., 74102.

Seifert, R., 1977, Energy for the north; The near-term options: Northern Engineer, Univ. Alaska, Fairbanks, v. 9, no. 1, p. 29-35.

Seifert, W.K., Moldowan, J.M., and Jones, R.W., 1979, Application of biological. marker chemistry to petroleum exploration: World Petroleum Congress, Tenth Bucharest, Special Paper SP8, p. 425-440.

Selkregg, L.L., 1975, Alaska regional profiles, arctic region: AEIDC, Anchorage, University of Alaska, $218 \mathrm{p}$.

Sellman, P.V., 1977, Delineation and engineering characteristics of permafrost beneath the Beaufort Sea, in Annual report of the principal investigators: v. 16, Hazards: OCSEAP NOAA/BLM, p. 385-395.

, 1976, Delineation and engineering characteristics of permafrost beneath the Beaufort Sea: Geology, v. 12, p. 391-466.

Sellman, P.V., Chamberlain, E.J. and Delaney, A., 1980, Delineation and engineering characteristics of permafrost beneath the Beaufort Sea, in Annual reports of the principal investigators, V. 4, Hazards: OCSEAP, NOAA/BLM, p. 124-158.

Sellmann, P.V., Chamberlain, E.J., and others, 1978, The classification and geomorphic implications of thaw lakes in the Arctic coastal plain, Alaska; in annual reports of the principal investigators, v. 9, Hazards: OCSEAP NOAA/BLM, p. 50-74.

Sellmann, P.V., and others, 1975, The classification and geomorphic implications of thaw lakes in the Arctic coastal plain, Alaska: CRREL Research Report $344,20 \mathrm{p}$.

Sellman, P.V., and Chamberlain, E.J., 1979, Permafrost beneath the Beaufort Sea, near Prudhoe Bay, Alaska, in: Annual offshore Technology Conference, Eleventh, Houston, Texas, Proceedings. 


\section{REFERENCES}

Sellmann, P.V., Chamberlain, E.J., Ueda, H.T., Blouin, S.E., Garfield, D.E., and Lewellen, R.I., 1977, Operational Report - 1977 CRREL-USGS Subsea Permafrost Program, Beaufort Sea, Alaska, U.S. Army Cold Regions Research and Engineering Laboratory Special Report 77-41 (1977).

Sellmann, P.V., Lewellen, R.I., Ueda, H.T., Chamberlain, E.J., and Blouin, S.E., 1976, Operational Report: 1976 USACRREL-USGS Subsea Permafrost Program, Beaufort Sea, Alaska, U.S. Army Cold Regions Research and Engineering Laboratory Special Report 76-12 (1976).

Shaw, D.G. 1976, Hydrocarbons; natural distribution and dynamics of the Alaskan Outer Continental Shelf: in Annual reports of the principal investigators v. 10, Chemistry and microbiology: OCSEAP, NOAA/BLM, p. 196-316.

Shaw, D.G., Smith, E.R., and McIntosh, D.J., 1977, Aromatic hydrocarbons in Recent sediments of the Beaufort Sea; distribution and sources [abs.]; GSA Abstracts with programs, v. 9, no. 7, p. 1171.

Shawe, D.R., ed., 1976, Geology and resources of fluorine in the United States: U.S. Geological. Survey Professional Paper 933, 99 p.

Shearer, G.B., and Miller, D.L., 1979, Geotechnical investigation, Beaufort Sea, Alaska, 1979, [abs.]: Alaska Science Conference Proceedings no. 30, p. 31 .

Sheils, M., Reese, M., and Cook, W.J., 1979, Again, a gold rush in frigid Alaska; Beaufort Sea, Newsweek, Dec. 24, v. 944, p. 62-63.

She11, 1978, She11: Alaska holds 58 percent of future U.S. oil finds, Oil and Gas Journal, Nov. 20, 1978, p. 214.

Short, A.D., 1974, Beach dynamics and nearshore morphology of the Alaskan Arctic coast [abs.]: Baton Rouge, Louisiana State Univ., PH.D. Thesis, (Dissertation Abstracts International, v. 34, no. 9, p. 4488B-4489B.)

, 1975, Offshore bars along the Alaskan arctic coast; Journal of Geology, v. 83 no. 2 , p. 209-222.

, 1976, Barrier island development along the Alaskan Arctic/coastal plain [abs.]: International Geology Congress Abstracts - Congress Geology International, Resumes, 25, v. 2, (Sect. 8, Marine geology, exploration, depositional environments) p. 356-357, 1976.

, 1979, Barrier Island development along the Alaskan-Yukon coastal plains, summary: GSA Bulletin, v. 90, no. 1, I3-I5, II27-II103.

Short, A.D., Coleman, J.M., and Wright, L.D., 1974, Beach dynamics and nearshore morphology of the Beaufort Sea coast, Alaska; in Reed, J.C. and Slater, J.E., eds, The coast and shelf of the Beaufort Sea: Arlington, Va., Arctic Institute of North America, p. 477-488.

Short, A.D., and Wiseman, W.J., Jr., 1975, Coastal breakup in the Alaskan Arctic: GSA Bulletin, no. 86, no. 2, p. 199-202. 


\section{REFEKENCES}

Short, A.D., and Wright, L.D., 1974, Lineaments and coastal geomorphic patterns in the Alaskan Arctic: GSA Bulletin, v. 85, no. 6, p. 931-936.

Simon, R.B., Stover, C.W., Person, W.J., and Minsch, J.H., 1978, Earthquakes in the United States, January-March 1976: U.S. Geological Survey Circular 766-A, p. A1-A33.

Singletary, M.K., 1978, Status report, oil and gas industry Alaska - August, 1978: Paper 7 in Alaska Mineral Development, Rocky Mountain Mineral Law Foundation, Anchorage, Alaska.

Skibitzke, H.E., 1974, Sone aspects of remote sensing for consideration in planning for environmental monitoring of the Alyeska Pipeline, Alaska: U.S. Geological Survey, Open-file Report, 77-643, $33 \mathrm{p}$.

Skladel, G.W., 1974, The coastal boundaries of Naval Petroleum Reserve No. 4: Fairbanks, Univ. Alaska, Sea Grant program, 19 p.

Slack, K.V., Nauman, J.W., and Tilley, L.J., 1977, Benthic invertebrates in an arctic mountain stream, Brooks Range, Alaska: U.S. Geological Survey Journal Research, v. 5, no. 4, p. 519-527.

Sliter, W.V., 1979, Cretaceous foraminifers from the North Slope of Alaska, in Ahlbrandt, T.S., ed., Preliminary geologic, petrologic, and paleontologic results of the study of Nanushuk Group rocks, North Slope, Alaska: U.S. Geological Survey Circular 794, p. 147-157.

Sloan, C.E., 1977, Arctic hydrology studies, in Blean, K.M., ed., The United States Geological Survey in Alaska: Accomplishments during 1976: U.S. Geological Survey Circular 751-B, p. B30-B31.

Sloan, C.E., and Snyder, R.F., 1978, Hydrologic reconnaissance of lakes in NPRA, 1977, in Johnson, K.M., ed., The United States Geological Survey in Alaska; Accomplishments during 1977: U.S. Geological Survey Circular $772-\mathrm{B}, \mathrm{P} . \mathrm{B} 28-\mathrm{B} 29$.

Sloan, Charles, Trabant, Dennis, and Glude, William, 1978, Reconnaissance snow survey of NPRA, April 1977, in Johnson, K.M., ed., The United States Geological Survey in Alaska; Accomplishments during 1977: U.S. Geological Survey Circular 772-B, p. B28.

, 1979, Reconnaissance snow surveys of the National Petroleum Reserve in Alaska, April 1977 and April-May 1978: U.S. Geological Survey WaterResources Investigations Open-file Report 79-1342, 31 p.

Sloan, C.E., Zenone, Chester, and Mayo, L.R., 1975, Icings along the transAlaska pipeline route: U.S. Geological Survey Open-file Report 75-87, 39 p. , 1976, Icings along the trans-Alaska pipeline route: U.S. Geological Survey Professional Paper 979, $31 \mathrm{p}$. 


\section{REFERENCES}

Smith, E.R., 1976, Petroleum in benthic sediments in Prudhoe Bay, Alaska [abs.], in West, G.C., ed., Science in Alaska 1976: Alaska Sci. Conf. Proc., no. $\overline{27}$, v. 1, p. 173 .

Snowdon, L.R., 1980, Petroleun source potential of the Boundary Creek Formation, Beaufort-Mackenzie Basin: Bulletin of Canadian Petroleum Geology, v. 28, no. $1, \mathrm{p} \cdot 46-58$.

Sobczak, L.W., 1978, Gravity from $60^{\circ} \mathrm{N}$ to the North Pole, in J.F. Sweeney, ed., Arctic Geophysical Review: Department of Energy, Mines and Resources, of Canada, Branch of Earth Physics v. 45 no. 4, p. 67-74, Plate 3.

State of Alaska, 1978, Statistical keport: Anchorage, State of Alaska, Alaska 0i1 and Gas Conservation Commission, 262 p.

Steele, W.C., Le Compte, J.R., and Albert, N.R.D., 1979, Landsat data interpretation for various AMRAP quadrangles, Alaska, in Johnson, K.M., and Williams, J.R., eds., The United States Geological Survey in Alaska; Accomplishments during 1978: U.S. Geological Survey Circular 804-B, p. B3-B4.

Still, Patsy, J., 1976, Index of surface water quality records to Sept. 30, 1973, Northwest Alaska and Arctic Slope, Alaska: U.S. Geological Survey, Alaska District, Water Resources Division, Open-file Report, 9 p.

Sti.11, P.J., 1980a, Index of streamflow and water-quality records to September 30, 1978, Arctic Slope Alaska: U.S. Geological Survey Open-file Report 80$554,18 \mathrm{p}$.

, 1980b, Index of streamflow and water-quality records to September 30 , 1978, northwest Alaska: U.S. Geological Survey Open-file Report 80-553, $19 \mathrm{p}$.

Still, P.J., 1980c, Index of streamflow and water-quality records to Septernber 30, 1978, Yukon Basin, Alaska: U.S. Geological Survey Open-file Report $80-552,41 \mathrm{p}$.

Stringer, W.J., 1976, Morphology of Beaufort nearshore ice conditions by means of satellite and aerial sensing; in Annual report of the principal

investigators $v$. 14, Ice: OCSEAP, TOAA/BLM, p. 251-311.

, 1979, Morphology and hazards related to nearshore ice in Alaskan Coastal Areas; in International Conference on Port and Ocean Engineering under Arctic Conditions, Fifth, Trondheim, Norway, Proceedings: v. 1 p. 1-22.

Stringer, W.J., Barrett, S.A., and Balvin, N., 1977, Morphology of Beaufort, Chukchi and Bering seas near shore ice conditions by means of satellite and aerial remote sensing, in Annual reports of the principal investigators v. 15, Transport: OCSEAP, NOAA/BLM, p. 42-150.

Sweeney, F.J., ed., 1978, Arctic geophysical review; Department of Energy, Mines Resources Canada, Earth Physics Branch, Ottawa, Canada, v. 45, no. 4, $108 \mathrm{p}$. 


\section{REFERENCES}

Sweeney, F.J., Coles, R.L., DeLaurier, J., Forsyth, D.A., Irving, E., Judge, A., Sobczak, L.W., and Wetmiller, R.J., 1978, Arctic geophysical review and evolutionary history [abs.]: GSA Abstracts with Programs, v. 10, no. 7 , p. 502 .

Sweeney, F.J., 1980, History of Canda Basin margin, Arctic Ocean [abs.]: EOS, American Geophysical Union Transactions, v. 61, no. 46, p. 1100, no. T5.

Tailleur, I.L., Bird, K.J., and Engwicht, S.E., 1978, Map showing depth to basement from drilling and from seismic exploration, eastern North Slope petroleum province, Alaska: U.S. Geological Survey Miscellaneous Field Studies Map MF-928U, 1 sheet, scale 1:500,000.

Tailleur, I.L., and Brosge, W.P., 1975, Coal resources of northern Alaska may be nation's largest; in Rao, P.D., and others eds., Focus on Alaska's coal. 175: proceedings of the conference held at the University of Alaska Alaska, Fairbanks, Univ. MIRL Rept. 37, p. 219-226.

, 1976, Need to revise and test estimates of northern Alaska coal resources, in Cobb, E.H., ed., The United States Geological Survey in Alaska:

Accomplishments during 1975: U.S. Geological Survey Circular 733, p. 26-27.

Tailleur, I.L., Ellersieck, I.F., and Mayfield, C.F., 1977, Mineral resources of the western Brooks Range, in Blean, K.M., ed., The United States Geological Survey in Alaska; Accomplishments during 1976: U.S. Geological Survey Circular 751-B, p. B24-B25.

Tailleur, I.L., Engwicht, S.E., 1978a, Generalized structure map of top, middle, and basal Tertiary markers with geothermal gradients, eastern North Slope petroleum province, Alaska: U.S. Geological Survey Miscellaneous Field Studies Map MF-928B, 1 sheet, scale 1:500,000.

Tailleur, I.L., and Engwicht, S.E., 1978b, Seismic maps of shallow Cretaceous horizons, eastern North Slope petroleum province, Alaska: U.S. Geological Survey Miscellaneous Field Studies Map MF-928G, 1 sheet, scale 1:500,000.

, 1978c, Structure maps of top of Sadlerochit Group, and cross sections of Sadlerochit reservoir, eastern North Slope petroleum province, Alaska: U.S. Geological Survey Miscellaneous Field Studies Map $\mathrm{MF}-9280,1$ sheet, scale $1: 500,000$.

Tailleur, I.L., Mayfield, C.F., and Ellersieck, Inyo, 1980, Exploration guides for lead and zinc in the western brooks Range, Alaska: Paper presented at Alaska Miners Association Annual Meeting, Anchorage, Oct. 1980, unpublished.

Tailleur, I.L., and Pessel, G.H., 1976, Subsurface geology and some implications concerning future petroleum exploration in eastern Arctic slope, Alaska (abs.): AAPG Bulletin, v. 60, no. 12, p. 2190. 


\section{REFERENCES}

Tailleur, I.L., and Pessel, G.H., and Engwicht, S.E., 1978, Subcrop map at Lower Cretaceous unconformity, and maps of Jurassic and Lower Cretaceous seismic horizons, eastern North Slope petroleum province, Alaska: U.S. Geological Survey Miscellaneous Field Studies Map MF-9281, 1 sheet, scale $1: 500,000$.

Tailleur, I.L., Pesse1, G.H., Levorsen, J.A., and Engwicht, S.E., 1978, Maps showing land status and well locations and tables of well data, eastern North Slope petroleum province, Alaska, with a section on exploration by H.C. Jamison: U.S. Geological Survey Miscellaneous Field Studies Map MF-928A, 8 p., 5 sheets, scale 1:500,000.

Tasch, P., 1979, Fossiliferous beach, gravels, Barrow, Alaska; preliminary observations [abs.]: in Kansas Academy of Science, third annual meeting Kansas Academy Science Transactions, v. 82, no. 2, p. 100.

Tectonophysics, 1975a, v. 29, p. 73-85, Active faults of Alaska, G.E. Borgan. , 1975b, v. 29, p. 87-102, New data on plate tectonics of Alaska, by D.R. Packer and others.

Tedrow, J.C.F., 1977, Soils of the polar landscapes: New Brunswick, N.J., Rutgers University Press, $638 \mathrm{p}$.

Tetra Tech, 1978, Summary geologic report FY-78 (J. Andrews and R.M. Pratt): unpublished, TC-7158.

, 1979, Interpretation of the FY-77 seismic survey data, NPRA, revised May, 1978: NOAA, National Geophysical and Terrestrial Data Center, Boulder, Colorado, $1: 250,000$.

, 1980, Summary geologic report FY-80 (Guldenzopf, E.C., Orlovsky, M.B., Higgs, D.A., Freytag, C.G., and Ovalle, E.R.): unpublished TC-7168.

, 1980, Summary geophysical report FY 1978: [unpublished].

Theobald, P.K., and Barton, H.N., 1978, Basic data for the geochemical evaluation of National Petroleum Reserve, Alaska: U.S. Geological Survey Open-file Report 78-70-D, 102 p., 2 pl.

Theobald, P.K., Barton, H.N., Billings, T.M., Frisken, J.G., Turner, R.L., and Van Trump, George, Jr., 1978, Geochemical distribution of elements in stream sediments and heavy-mineral concentrate samples in the southern half of the National Petroleum Reserve, Alaska: U.S. Geological Survey Open-file Report, 78-517, 1 sheet.

Time Magazine, 1979, Hot prospect; U.S.'s Beaufort Sea sector: December 24, v. 114, p. 24 .

Toimil, L.J., 1978, Ice-gouged morphology on the floor of the eastern Chukchi Sea, Alaska, A reconnaissance survey: U.S. Geological Survey Open-file Report 78-693, $94 \mathrm{p}$. 


\section{REFERENCES}

Toimil, L.J., and Grantz, Arthur, 1976, Origin of a bergfield in the northeastern Chukchi sea and its influence on the sedimentary environment, in Alma Johnson, ed., Arctic ice dynamics joint experiment: Seattle, Univ. Washington Division of Marine Resoources, (AIDJEX) Bulletin no. 34, 42 p.

, 1976, Seabed morphology adjacent to an "island" of grounded ice in the Arctic Ocean northwest of Point Barrow, in Cobb, E.H., ed., The United States Geological Survey in Alaska; Accomplishments during 1975: U.S. Geological Survey Circ. 733, p. 16-19.

Toimil, L.J., Reimnitz, Erk., and Grantz, Arthur, 1978, Ice gouged sea bed morphology of the eastern Chukchi Sea, Alaska: U.S. Geological Survey OpenFile Report 78-693.

Townsend, J.B., 1978, Improvements in magnetic observatory construction and operation in permafrost areas: U.S. Geological Survey Open-file Report $78-213,17 \mathrm{p}$.

Triplehorn, D.M., 1976, Volcanic-ash partings in coal; characteristics and stratigraphic significance [abs]: AAPG Bulletin, v. 60, no. 12, p. 2191.

Truett, J.C., 1978, Beaufort Sea Barrier Island -- lagoon ecological process studies; in Annual Reports of the principal investigators, v. VIII, Effects: OC̄EAP, NOAA/BLM, p. 406-466.

Tucker, R.W., and Burrell, D.C., 1977, The sedimentary environment of a lagoon on the Beaufort Sea coast of Alaska: Fairbanks, University of Alaska, Institute of Marine Science, Marine Science Communications, v.3 no. 2, p. $93-116$.

Turner, D.L., and Wilson, F.H., 1975, Radiometric dates from Alaska -- A 1975 compilation: Alaska Division of Geological and Geophysical Surveys Special Report 10, 64 p.

University of Alaska, Geophysical Institute Arctic Coastal Engineering Program, 1975, Characteristics and distribution of nearshore permafrost, Bering Sea: Fairbanks, Univ. Alaska. , 1975, Sea ice dynamics and properties, Beaufort Sea: Fairbanks, Alaska 99701.

Updike, R.G., and Howland, M.D., 1979, Surficial geology and processes, Prudhoe Bay oil field, Alaska, with hydrologic implications: Alaska Division of Geological and Geophysical Surveys Special Report 16, 6 p., 17 plates.

U.S. Army Corps of Engineers, 1980, Draft environmental impact statement Prudhoe Bay Oil Field, Waterflood project, 2 v.: U.S. Army Corps of Engineers, Alaska District, 3 vol.

U.S. Army Corps of Engineers, Alaska District, 1975, Harbors and rivers in Alaska, survey report, Interim Report 6, northwestern Alaska, in Dorris, J.D., Inventory of the Arctic region, Surface water resources and development: Joint Federal-State Land Use Planning Commission Planning Team (1973), $313 \mathrm{p}$. 
U.S. Bureau of Land Management, 1978a, Draft environmental impact statement proposed federal/state oil and gas lease sale, Beaufort Sea: U.S. Department of the Interior, $166 \mathrm{p}$.

, 1979, Final environmental impact statement proposed five-year OCS lease sale schedule larch 1980-February 1985: U.S. Department of the Interior, Washington, D.C.

, 1978b, Preliminary recommendation and use options National Petroleum Reserve in Alaska.

U.S. Bureau of Mines, Alaska Field Operations Center, 1975, Alaska minera1 find reported by Mines Bureau: Alaska Division of Geological and Geophysical Surveys Mines and Geology Bulletin v. 24 no. 6, p.3.

, 1977a, Mineral resources assessment, National Petroleum Reserve, Aalska Part II Interim report Nov. 15, 1977.

, 1977b, States of the mineral industries, 1977-mining, minerals, metals, mineral reclamation: U.S. Department of the Interior, Bureau of Mines.

, 1978a, Mineral appraisal of the proposed gates of the Arctic Wilderness National Park, Alaska: a preliminary comment: U.S. Bureau of Mines Open-file Report 109-78, 29 p.

, 1978b, Mineral appraisal of the proposed Kobuk Valley National Park, Alaska: a preliminary comment: U.S. Bureau of Mines Open-file Report $110-78,31 \mathrm{p}$.

, 1978c, Mineral data appraisal of the proposed Noatak National Ecological Reserve, Alaska: a preliminary comment: U.S. Bureau of Mines Open-file Report $67-78,33 \mathrm{p}$.

, 1978d, Mineral commodity summaries, 1978 - An up-to-date summary of 95 mineral commodities: U.S. Department of the Interior, Bureau of Mines.

, 1978e, Minerals and materials/A monthly survey (Oct. 1978): U.S. Department of the Interior, Bureau of Mines.

, 1979a, A mineral appraisal of areas traversed by the Salmon and Noatak Rivers in the western Brooks Range: A summary report: U.S. Bureau of Mines Open-file Report 50-79, 16 p.

, 1979b, A mineral appraisal of the areas traversed by the Kobuk, Killik, Alatna and John Rivers and the North Fork of the Koyukuk River, Brooks Range, Alaska: A summary report: U.S. Bureau of Mines Open-file report $36-79,23 \mathrm{p}$.

, 1980, Mineral appraisal of the proposed Utukok and Colville Wild and Scenic Rivers: a summary report: U.S. Bureau of Mines Open-file Report $37-80,8 \mathrm{p}$. 


\section{REFERENCES}

U.S. Department of Energy, 1979, DOE/EIA-0194/7, Model Documentation Report, Alaskan hydrocarbon supply model; methodology description, Appendix 1 .

Data documentation: $369 \mathrm{p}$.

U.S. Department of the Interior, Bureau of Land Management, WAMA Task Force, 1980, Western Arctic Management Area, Multiple Use Plan, preliminary draft.

U.S. Department of Interior, 1978, Final environmental impact statement, Proposed oil. and gas lease sale, Beaufort Sea, Alaska: Washington, D.C., U.S. Department of the Interior, $3 \mathrm{v}$.

U.S. Department of Interior, Fish and Wildlife Service, and Office of Research and Development, U.S. Environmental Protection Agency, 1980, Gravel removal guidelines manual for Arctic and subarctic floodplains: FWS/OBS-80-09.

U.S. Department of the Interior, Office of Minerals, Policy and Research Analysis, 1979, Final report of the 105(b) economic and policy analysis: alternative overall procedures for the exploration, development, production, transportation and distribution of the petroleum resources of the National Petroleum Reserve in Alaska (NPRA): 145 p.

U.S. Geological Survey, 1974a, Geological Survey research 1974: U.S. Geological Survey Professional Paper 900, 349 p.

, 1974b, Water resources data for Alaska, 1973, Part 1. Surface water records, Part 2. Water quality records, U.S. Geological Survey, 298 p. 1975a, Geological Survey research 1975: U.S Geological Survey Professional Paper 975, 373 p.

, 1975b, Water resources data for Alaska, 1974, Part 1. Surface water records, Part 2. Water quality records, U.S. Geological Survey, 322p.

U.S. Geological Survey, 1976a, Geological Survey research 1976: U.S Geological Survey Professional Paper 1000, $414 \mathrm{p}$.

, 1976b, Water resources data for Alaska, water year, 1975, U.S. Geological Survey Water-Data Report $A D-75-1,410 \mathrm{p}$.

, 1977a, Petroleum geology and hydrocarbon potential of Nat1 Petroleum Reserve No. 4, North Slope, Alaska, U.S. Geological Survey Open-File Report $77-475$.

1977b, Geological Survey research 1977: U.S Geological Survey Professional Paper 1050, 411 p.

, 1977c, Preliminary aeromagnetic map of the Brooks Range and Arctic Slope, Alaska: U.S. Geological Survey Open-file Report 77-166-E, scale $1: 1,000,000$.

, 1977d, Water resources data for Alaska, water year, 1976, U.S. Geological Survey, Water-Data Report, AD-76-1, 401 p. 


\section{REFERENCES}

U.S. Geologica1 Survey, 1978a, Geological Survey research 1978: U.S. Geological Survey Professional Paper $1100,464 \mathrm{p}$.

, 1978b, Folio, eastern North Slope petroleum province, Alaska, U.S. Geological Survey mineral investigations field studies maps, MF-928-A to $M F-928-V$.

, 1978c, NPRA Alaska multichannel (CDP) Seismic Reflection Data: National Geophysical and Solar-Terrestrial Data Center, flier 78-(Q-Q).

, 1978d, NPRA Well logs (1955-77): National Geophysical and SolarTerrestrial Data Center flier 1978(R).

U.S. Geological Survey, 1978e, Water resources data for Alaska, water year 1977, U.S. Geological Survey, Water-Data Report, AD-77-1, 439 p.

, 1979a, An environmental evaluation of potential petroleum development on the National Petroleum Reserve in Alaska, prepared under Section 105(b)

of the Naval Petroleum Reserves Production Act of 1976: U.S. Department of the Interior, Geological Survey, 238 p.

, 1979b, Beaufort: Sea, corehole data: NGSDC, flier 1979 (R-R).

, 1979c, NPRA interpretation of seismic survey data FY-77 (Report): National Geophysical and Solar-Terrestrial Data Center, flier 1979 ( $\mathrm{T})$.

, 1979d, Geological Survey research 1979: U.S. Geological Survey Professional Paper 1150, $447 \mathrm{p}$. , 1979e, NPRA well logs (1977-78): National Geophysical and SolarTerrestrial Data Center, flier 1979(U).

U.S. Geological. Survey, 1980a, NPRA miscellaneous geological reports: NGSGC, flier $1980(\mathrm{SE}-\mathrm{FF})$.

, 1980b, NPRA palynology and micropaleontology reports, NGSDC, flier $1980(\mathrm{SE}-\mathrm{CC})$.

, 1980c, NPRA palynology and micropaleontlogy reports, 30 wells (1944-1979): National Geophysical and Solar-Terrestrial Data Center, flier 1980

$(\mathrm{SE}-1)$.

, 1980d, NPRA seismic data, 1977-78, and aerial gamma ray and magnetic survey: NGSDC, flier 1980 (SE-M).

, 1980e, NPRA Summary report; interpretation of seismic data (FY-78) NGSDC, flier 1980 (SE-DD).

, 1980f, NPRA velocity surveys for 7 additional wells: NGSDC, flier 1980 ( $\mathrm{SE}-\mathrm{EE})$. 


\section{REFERENCES}

U.S. Geological Survey, 1980g, NPRA Well logs (1978-79) and Sumnary Geologic Report (1978): National Geophysical and Solar-Terrestrial Data Center, flier $1980(\mathrm{SE}-\mathrm{J})$.

, 1980h, NPRA velocity surveys, 9 wells (1977-79): NGSDC, flier 1980 $(\mathrm{SE}-\mathrm{K})$.

, 1980i, NPRA Barrow area, geological and geophysical data and reports, NGSDC, flier 1980 (SE-L).

U.S. Department of the Navy, 1975, Final environmental impact statement, continuing exploration and evaluation of NPRA, Alaska (zone A): U.S. Department of the Navy, Naval Petroleum and 011 Shale Reserves, 347 p.

U.S. Department of the Navy, 1977, Final environmental impact statement -continuing exploration and evaluation of Naval Petroleum Reserve No. 4, Naval Petroleum and Oil Shale Reserves, 829 p.

U.S. National Research Council, National Academy of Sciences, 1975, The Alaska Oil pipeline; in Bete, F., Jr., ed., Environmental geology, v. 25, p. 160-172 illus., Dowden, Hutchinson \& Ross, Inc. Stroudsburg, Pa. (reprint from Earth and Human Affairs, 1972).

U.S. News, 1979, 01d struggle flares again over Alaska oil; Beaufort Sea, December 24 , vol. 87, p. 37.

U.S. Senate, 1974a, Committee on Interior and Insular Affairs, An assessment of mineral resources in Alaska: by U.S. Geological Survey, U.S. Bureau of Land Management, $69 \mathrm{p}$.

, 1974b, Committee Print, Serial n. 93 - 5l, In place volumetric determination of reservoir fluids Sadlerochit formation, Prudhoe Bay field, p. 126-175, in the Trans-Alaska Pipeline and west coast petroleum supply, $1977-1982$.

Van de Kamp, P.C., 1979, Stratigraphy and diagenetic alteration of Ellesmerian sequence siliciclastic rocks, North Slope, Alaska: Napa, 56 p. (Avaliable from National Oceanic and Atmospheric Administration, Mail Code D621, Boulder, Colorado 80303.)

Van Dyke, W.P., 1980, Proven and probable oil and gas reserves, North Slope, Alaska: State of Alaska, Department of Natural Resources, Division of Minerals and Energy Management, $11 \mathrm{p}$.

Van Poollen, H.K., and Associates, Inc., 1974, In place volumetric determination of reservoir fluids Sadlerochit Formation, Prudhoe Bay field: Report prepared for State of Alaska, Department of Natural Resources, Anchorage, Alaska, $41 \mathrm{p}$.

, 1976, Prediction of reservoir fluid recovery Sadlerochit Formation, Prudhoe Bay field; prepared for Alaska Department of Natural Resources, Division of $0 i 1$ and Gas, 1977, Supplement A. 


\section{REFERENCES}

Vigdorchik, M.E., 1980, Submarine permafrost on the Alaskan continental shelf: in collection, Westview special studies in earth sciences, Westview Press, Boulder, Colorado, U.S., 109 p.

Vogt, P.R., and Avery, O.E., 1974, Tectonic history of the Arctic Basins: Partial solutions and unresolved mysteries, in Y. Herman, ed., Marine geology and Oceanography of the Arctic Seas, Springer, New York, N.Y., p. 83-118.

Wadham, P., 1979, Ice characteristics in the seasonal sea ice zone: Paper presented at a symposium at the U.S. Navy Postgraduate school.

Wadham, D.H., Lamprecht, D.E., and Mrosousky, Ivan, 1979, Joint geologic/engineering analysis of the Sadlerochit Reservoir, Prudhoe Bay Field: Journal of Petroleum Technology, July, 1979, p. 933-940.

Walker, D.A., and others, 1980, Geobotanical atlas of the Prudhoe Bay region, Alaska: CRREL Report 80-14 (in press).

Walker, F.K., 1975, Bibliography and index of U.S. Geological Survey publications relating to coal, January 1971-June 1974: U.S. Geological Survey Circular $709,14 \mathrm{p}$.

Walker, H.J., 1974, The Colville River and the Beaufort Sea; some interactions: in Reed, J.C., ed., The coast and shelf of the Beaufort Sea: Arlington, Va. Arctic Institute of North America, p. 513-540.

, 1976a, Depositional environments of the Colville River delta: in Miller, T.P., ed., Recent and ancient Sedimentary environments in Alaska: Alaska Geological Society, Anchorage, Alaska, p. C1-C22.

, 1976b, Lake topping in the Colville River delta, Alaska: International Conference on Permafrost, Proc. no. 3, v. 1, p. 232-238.

, 1978, Measurement along Arctic coasts: in Tanner, W.F., ed., Standards for measuring shoreline changes; a study of the precision obtainable, and needed, in making measurements of changes (erosion and accertion): 3rd edition, Coastal Res. Tallahassee, Fla. State Univ., p. 59-61.

Walker, H.J., and Harris, M.K., 1976, Perched ponds, An arctic variety: Arctic, v. 29 , no. 4 , p. 223-238.

Wanek, A.A., 1974, Coal in Alaska [abs]: American Association of Petroleum Geologists Bulletin, v. 58, no. 7, p. 1461.

Ward, D.L., and Peterson, L.A., 1976, A summary of water use problems related to North Slope petroleum development; in Science in Alaska, 1976, Resource development -- processes and problems, Vo1. II: Proceedings of the $27 \mathrm{th}$ Alaska Science Conference, Fairbanks, p. 53-57.

Washburn, A.L., 1980, Geocryology: A survey of periglacial processes and environments: New York; John Wiley \& Sons, 406 p. 


\section{REFERENCES}

Watts, A.B., and Ryan, W.B.F., 1976, Flexure of the lithosphere and continental margin basins: Tectonophysics v. 36 p. 25-44.

Weeks, W.F., and Kovacs, A., 1979, Dynamics of nearshore ice; in Annual Reports of the principal investigators, OCSEAP, NOAA/BLM.

Weiss, H.V., and others, 1974, Mercury in the environs of the llorth Slope of Alaska: in Reed, J.C., and Slater, J.E. eds., the Coast and Shelf of the Beaufort Sea: Arlington, Va., Arctic Institute of North America, p. 737-746.

Weller, G., 1976, The role of sea ice in the arctic coastal environment: in Norton, D.W., ed., Science in Alaska, 1976; resource development, processes and problems Alaska Science Conference, $27 \mathrm{th}$, Proceedings, no. 27, v. 2, p. 133-149.

Weller, M.W., and Derksen, D.V., 1979, The geomorphology of Teshekpuk Lake in relation to coastline configuration of Alaska's coastal plain: Arctic, v. 32, no. 2, p. 152-160.

Weller, G., and Norton, D.W., 1977, $0 i 1$ in the Arctic 2, The Outer Continental Shelf environmental assessment program: Interdisciplinary Science Reviews, v. 2, no. 3, p. 215-226.

Weller, G., Norton, D.W., and Johnson, T., eds., 1977, Beaufort Sea synthesis report, draft: Proceedings of synthesis meeting of OCSEAP and other investigations in northern Alaska, Barrow: Univ. of Alaska, Fairbanks. Arctic Project Bulletin - Special Bulletin 15, 219 p.

Wellman, J.H., Clarke, E.S., and Condo, A.C., 1976, Design and constructuion of synthetically insulated gravel pads in the Alaskan arctic, in International Symposium on Cold Regions Engineering, Fairbanks, Second, Proceedings, p. $62-85$.

West, G.C., 1976, Environmental problems associated with arctic development. especially in Alaska: Environmental Conservation, v. 3 no. 3, p. 218-224.

Westmiller, R.J., and Forsyth, D.A., 1978, Seismicity of the Arctic, 1908-1975, in Arctic geophysical review L.J.F., Sweeney, ed., Publications of the Earth Physics Branch, Canadian Department of Energy, Mines and Resources, v. 45, no. 4, p. 15-24.

White, L.P., 1979, A play approach to hydrocarbon resource assessment and evaluation: in Conference on the Economics of Exploration for Energy Resource, Second, New York Univ., May 17-18, 1979, Proceedings.

Williams, J.R., 1979, Stratigraphy of the Gubik Formation at Skull Cliff, northern Alaska, in Johnson, K.M., and Williams, J.R., eds., the United States Geological Survey in Alaska: Accomplishments during 1978: U.S. Geological Survey Circular 804-B, p. B31-B33.

Williams, J.R., Carter, L.D., and Yeend, W.E., 1978, Coastal plain deposits of NPRA, in Johnson, K.M., ed., U.S. Geological Survey in Alaska ; Accomplishments during 1977: U.S. Geological Survey Circular 772-B, p. $\mathrm{B} 20-\mathrm{B} 22$. 


\section{REFERENCES}

Williams, J.R., and Yeend, W.E., 1979, Deep thaw lake basins of the inner Arctic Coastal Plain, Alaska, in Johnson, K.M., and Williams, J.R., eds., U.S. Geological Survey in Alaska; Accomplishments during 1978: U.S. Geological Survey Circular $804-B$, p. B35-B37.

Williams, J.R, Yeend, W.E., Carter, L.D., and Hamilton, T.D., 1977, Preliminary surficial deposits map of National Petroleum Reserve - Alaska: U.S. Geological Survey Open-file Map 77-868, 2 sheets, scale 1:500,000.

Williams, P.J., 1979, Pipelines and permafrost: Physical geography and deve1opment in the circumpolar North: in Collection, Topics in applied geography, London, U.K., Longman, $\overline{92}$ p.

Wilson, F.H., and Turner, D.L., 1975, Radiometric age map of Alaska -- Northern Alaska: Alaska Divison of Geological and Geophysical Surveys Open-file Report AOF-86, 11 p., map.

Wilson, H.M., 1977, New field may be shaping up east of Prudhoe: 0il and Gas Journal, p. 104-105, Nov. 14, 1977.

Wilson, Howard, 1979, Dinkum Sands disappearance threatens Beaufort Sea sale, August 13, v. 77 , no. 33, p. 50.

Wilson, H.M., 1979, Beaufort Sea high bids top \$1 billion, in Oil and Gas Journal, Dec. 17, v. 77 , p. 26-29.

, 1980, Alaska/Canada; Operators poised for Beaufort Drilling: Oil and Gas Journal, v. 78, no. 8, p. 55-62.

Witmer, R.J., 1980, Availability of palynomorph and foraminifera microscope slides from test wells of National Petroleum Reserve in Alaska: Group I: U.S. Geological Survey Open-file Report 80-193, 21 p.

Witten, Wesley, 1978, Harnessing Arctic energy - Trans-Alaska pipeline [abs.]: AAPG Bulletin, v. 62 , no. 7, p. 1239.

Wood, G.V., and Armstrong, A.K., 1975a, Diagenesis and stratigraphy of the Lisburne Group limestones of the Sadlerochit Mountians and adjacent areas, northeastern Alaska: U.S. Geological Survey Professional Paper 857,47 p.

Woodward-Clyde Associates, 1976, Preliminary report gravel removal studies in selected arctic and subarctic streams in Alaska: For U.S. De!partment of Interior, Fish and Wildlife Service, office of Biological Services, 76/21, $127 \mathrm{p}$.

, 1978, Offshore Alaska seismic exposure study (OASES): for the Alaska subarctic offshore committee (ASOC), Exxon Co.

, 1980a, Gravel removal studies in Arctic and subarctic floodplains in Alaska: for the U.S. Fish and Wildlife Service, office of Biological. Services Technical Report $80 / 08$. 
Woodward-Clyde Associates, 1980, Gravel removal guidelines manual in arctic and subarctic floodplains in Alaska: for U.S. Fish and Wildlife Service; office of Biological Services Technical Report 80/09.

Work, P.L., 1980, NPR-Alaska, An update [abs.]: Geophysics, v. 45, no. 8, p. 1334 .

World Oil, 1975, What's ahead for the Navy's Alaskan petroleum reserve?, v. $181, \mathrm{n} .7$, December, p. 60-63.

World 0il, 1975, Prudhoe Bay field development is proceeding on schedule. v. 181, n. 7, Decenber, p. 64-68.

World Oil, 1975, Industry thinks it's ready to tackle offshore Alaska. v. $181, n .7$, December, p. 69-72.

World Petroleum Congress, 1975, 9th, Proceedings, v. 2, p. 223-228, Prediction of fluvial-deltaic reservoir geometry, Prudhoe Bay field, Alaska, by Eckelmann, W.R., Dewitt, R.J., and Fisher, W.L.

, 1975, Oil and gas developments in Arctic North America, by McIvor, D.K. and Gryc, George, 9th World Petroleum Congress, Proceedings, v. 3, p. 167-179.

Yeend, Warren, 1978, Surficial geology of the foothills and moutains of NPRA, in Johnson, K.M., ed., U.S. Geological Survey in Alaska - Accomplistıments during 1977: U.S. Geological Survey Circular 772-B, p. B19-B20.

Yorath, C.J., and Norris, C.K., 1975, The tectonic development of the southern Beaufort Sea and its relationship to the origin of the Arctic Ocean: Canadian Society of Petroleum Geologists Memoir 4, p. 589-61l.

Yorath, C.J., Parker, E.R., and Class, D.J., 1975, Canada's continental margins and offshore Petroleuri exploration: Canadian Society of Petroleum Geologists Memoir 4.

Young, Allen, Monaghan, P.H., and Schweissberger, R.T., 1977, Calculation of ages of hydrocarbons in oils - physical chemistry applied to petroleum geology: American Association of Petroleum Geologists Bulletin, v. 6l, no. 4, p. 573-600.

Young, E.G., 1975, Upper Cretaceous stratigraphy, Yukon coastal plain and northwestern MacKenzie Delta: Geological Survey of Canada Bulletin 249, 83 p.

Young, F.G., Myhr, D.W., and Yorath, C.J., 1976, Geology of the BeaufortMacKenzie basin, Geological Survey of Canada Paper 76-11, 65 p.

Yount, M.E., ed., 1975, U.S. Geological Survey Alaska program, 1975: U.S. Geological Survey Circular 722, 58 p.

Zimmerman, Jay, and Soustek, P.G., 1979, The Avan Hills ultramafic complex, DeLong Mountains, Alaska, in Johuson, K.M., and Williams, J.R., eds., U.S. Geological Survey in Alaska; Accomplishments during 1978: U.S. Geological Survey Circular 804-B, p. B8-B11. 
SOURCES

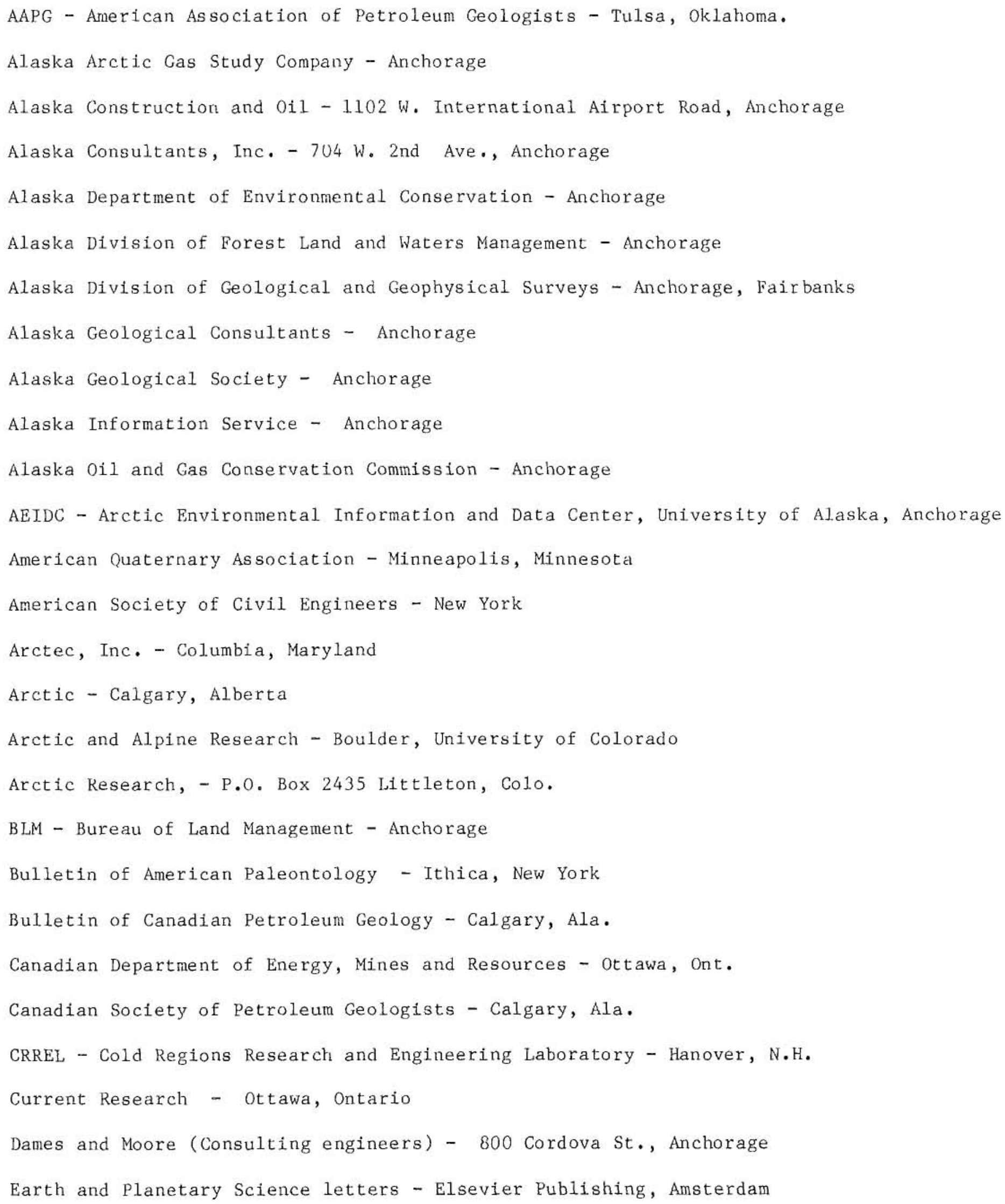


Earth Sciences Branch, Dept. of Energy, Mines, \& Resources, Canada - Ottawa, Ont. E1 Paso Natural Gas Co. - Anchorage

Environmental Research and Technology - Concord, Mass. 07142

Environmental Services, Ltd., - Anchorage

EOS, American Geophysical Union Transactions - Washington, D.C.

Geological Association of Canada - Toronto, Ont.

GSA - Geological Society of America - Boulder, Colo.

Geological Survey of Canada - Ottawa, Ont.

Geology - (Geological Society of America), Boulder, Colo.

Geophysics - Tulsa, Oklahoma, Society of Exploration Geophysicists

Harding-Lawson Associates - 624 W. International Airport Road, Anchorage

Houston Geological Society - Houston, Texas

Institute of Gas Technology - Chicago, Illinois

Institute of Marine Science, University of Alaska, Fairbanks

Interdisciplinary Science Reviews - Heydon and Son, London

Joint Federal State Land Use Planning Team - Anchorage

Journal of Geology - Chicago, University of Chicago Press

Journal of Geophysical Research, American Geophysical Union - Washington, D.C.,

Journal of Petroleum Technology (Society of Petroleum Engineers of the American Institute of Mining, Metallurgical and Petroleum Engineeers) - Dallas, Texas

Journal of Sedimentary Petrology, Society of economic Paleontologists and Mineralogists - Tulsa, Okla.

Kansas Academy of Science Transactions - Salina, Kansas

MIRL Report - Mineral Industry Research Laboratory, University of Alaska, Fairbanks Moening-Gray Associates - Anchorage

Monthly Weather Review - Washington, D.C.

NASA Technical Memo. - Washington, D.C.

NGSDC - National Geophysical and Solar-Terrestrial Data Center 


\section{SOURCES}

Northern Engineer - Fairbanks, University of Alaska Geophysical Institute

NTIS - National Technical Information Service (U.S. Dept. Commerce), - Springfield, Va. Newsweek - New York

NOAA - National Oceanic and Atmospheric Administration - Boulder, Colo.

Oceanographic Services, Inc. - Galvaston, Texas

Oceanweather, inc.

Offshore - Petroleun Publication Co., Tulsa, Okla.

Oil and Gas Journal - Pennwell Publishing Co., Tulsa, Okla.

OCSEAP (Outer continental shelf environmental assessment program, NOAA)

- Boulder, Colo.

Remote Sensing Environment - New York, N.Y.

Science - Washington, D.C.

Sea Ice Consultants, Inc. - Washington, D.C.

Society Exploration Geophysics - Tulsa, Okla.

Tectonophysics - Elsevier Science Pub. Co., Amsterdant

Tetra Tech, Inc. - Anchorage

U.S. Army Corps of Engineers - Anchorage

U.S. Bureau of Mines - Anchorage

U.S. Department of Agriculture Soil Conservation Service

U.S. Department of the Navy, Naval Petroleum and $0 i 1$ Shale Reserves

U.S. Federal Power Commission - Washington, D.C.

U.S. Fish and Wildlife Service - Anchorage

U.S. Geological Survey - Anchorage

Woodward-clyde, Associates - Anchorage

World Oil - Gulf Publishing, Houston, Texas

University of Washington, Department of Oceanography - Seattle, Wash. 
STAFF

Ross G. Schaff, State Geologist

D.D. Adams, Geological assistant R. Ahgupuk, Cartographer M.D. Albanese, Geological assistant R.D. Allely, Geological assistant M.R. Ashwell, Laboratory assistant W.W. Barnwell, Deputy State Geologist E.E. Becia, Planner

T.A. Benjamin, Chemist

N.J. Bragg, Administrative assistant

M.E. Brown, Land management officer

T.K. Bundtzen, Geologist

C.D. Burgess, Clerk-typist

L.E. Burns, Geological assistant

R.A. Clay, Geologist

J.G. Clough, Geological assistant

E.J. Collazzi, Geological assistant

C.N. Conwell, Mining engineer

P.L. Coonrod, Clerk-typist

C.L. Daniels, Publications specialist

L.L. Dearborn, Hydrologist

J.E. Decker, Geologist

J.T. Dillon, Geologist

G.R. Eakins, Geologist

K.S. Emmel, Geological assistant

W.G. Gilbert, Deputy State Geologist

J.J. Hansen, Geophysicist

S.B. Hardy, Geological assistant

M.W. Henning, Geologist

M.G. Inghram, Hydrologist

R.W. Ireland, Geologist

J.T. Kline, Geologist

K. Kline, Geological assistant.

R.W. Kornbrath, Geologist

K.J. Krause, Geologist

D.L. Krouskop, Geophysicist

G.M. Laird, Cartographer

F.L. Larson, Publications specialist
W.E. Long, Hydrologist W.M. Lyle, Geologist

R.A. Mann, Clerk

G.D. March, Geologist

D.L. McGee, Geologist

R.D. Merritt, Geologist

P.A. Metz, Geologist

J.F. Meyer, Geophysicist

W.H. Mitchell, Jr., Geological assistant

M.A. Moorman, Geological assistant

R.J. Motyka, Geologist

C.G. Mull, Geologist

D.J. Mursch, Clerk-typist

J.N. Newgaard, Accounting technician

K.S. Pearson, Cartographer

G.H. Pessel, Geologist

M.K. Polly, Laboratory assistant

M.E. Pritchard, Cartographer

S.E. Rawlinson, Geologist

J.W. Reeder, Geologist

R.D. Reger, Geologist

V.L. Reger, Clerk-typist

M.S. Robinson, Geologist

L.C. Schell, Cartographer

J.A. Sigler, Clerk-ty pist

T.E. Smith, Geologist

D.J. Solie, Geological assistant

D.R. Stein, Assayer

C.H. Stevenson, Geologic information technician

R.W. Stuvek, Clerk

C.A. Ulery, Geological assistant

R.G. Updike, Geologist

N.C. Veach, Assayer chemist

R.D. Wallace, Operations research analyst

S.M. Weum, Geophysicist

M.A. Wiltse, Geochemist

G.M. Zartman, Clerk 